\title{
GROUNDWATER PROTECTION MANAGEMENT PROGRAM
}

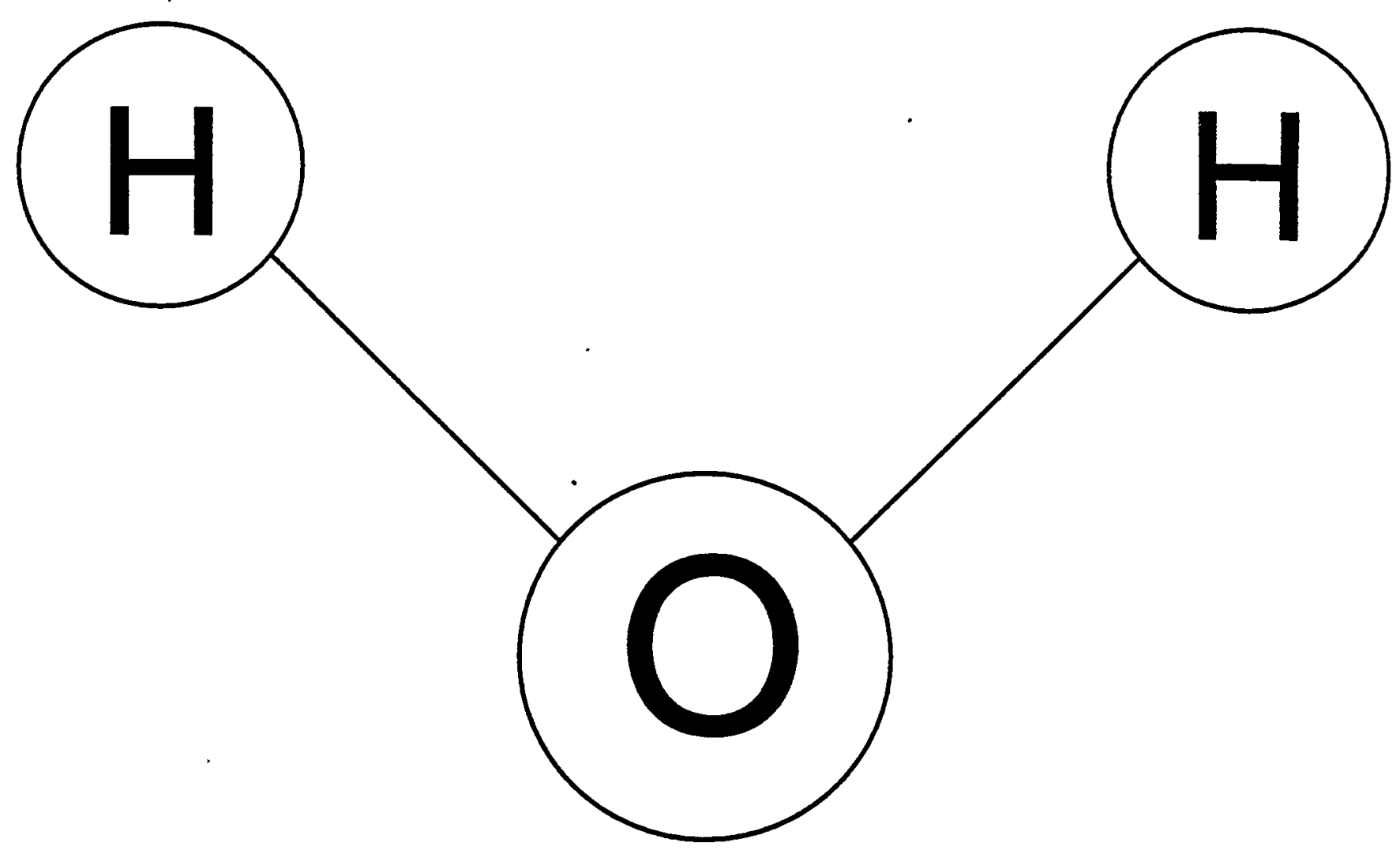

September 1999

Westinghouse Savannah River Company

Savannah River Site

Aiken, SC 29808 


\section{Groundwater Protection Management Program}

by

D. G. Wells

Westinghouse Savannah River Company

Savannah River Site

Aiken, South Carolina 29808

A. Odom (Contact)

5-1889

DOE Contract No. DE-AC09-96SR18500

This paper was prepared in connection with work done under the above contract number with the U. $S$.

Department of Energy. By acceptance of this paper, the publisher and/or recipient acknowledges the U.S. Government's right to retain a nonexclusive, royalty-free license in and to any copyright covering this paper, along with the right to reproduce and to authorize others to reproduce all or part of the copyrighted paper. 


\section{DISCLAIMER}

This report was prepared as an account of work sponsored by an agency of the United States Government. Neither the United States Government nor any agency thereof, nor any of their employees, makes any warranty, express or implied, or assumes any legal liability or responsibility for the accuracy, completeness, or usefulness of any information, apparatus, product, or process disclosed, or represents that its use would not infringe privately owned rights. Reference herein to any specific commercial product, process, or service by trade name, trademark, manufacturer, or otherwise does not necessarily constitute or imply its endorsement, recommendation, or favoring by the United States Government or any agency thereof. The views and opinions of authors expressed herein do not necessarily state or reflect those of the United States Government or any agency thereof.

This report has been reproduced directly from the best available copy.

Available to DOE and DOE contractors from the Office of Scientific and Technical Information, P. O. Box 62, Oak Ridge, TN 37831; prices available from (423) 576-8401.

Available to the public from the National Technical Information Service, U. S. Department of Commerce, 5285 Port Royal Road, Springfield, VA 22161. 


\section{DISCLAIMER}

Portions of this document may be illegible in electronic image products. Images are produced from the best available original document. 


\section{GROUNDWATER PROTECTION MANAGEMENT PROGRAM}

September 1999

Westinghouse Savannah River Company Savannah River Site Aiken, SC 29808 


\section{TABLE OF CONTENTS}

INTRODUCTION

1

GEOLOGY AND HYDROGEOLOGY

1.1 STRATIGRAPHY

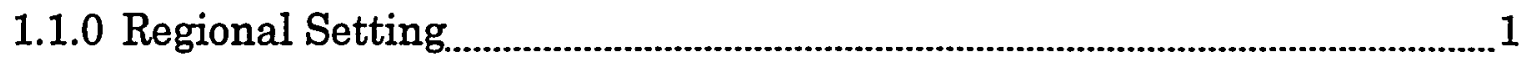

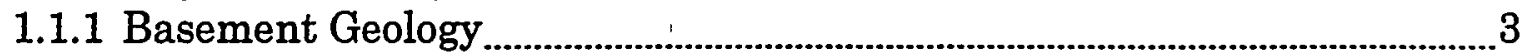

1.1.1.0 Introduction 3

1.1.1.1 Piedmont Province ...................................................................................4

1.1.1.2 Regional Geology of the Triassic-Jurassic Rift Basins .....................

1.1.2 Coastal Plain Sediments ..................................................................................

1.1.2.0 Introduction

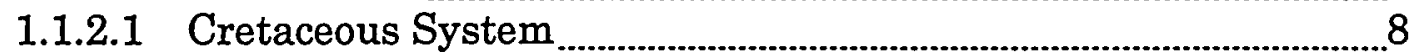

1.1.2.2 Tertiary System ................................................................................ 13

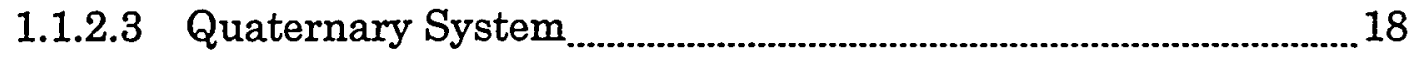

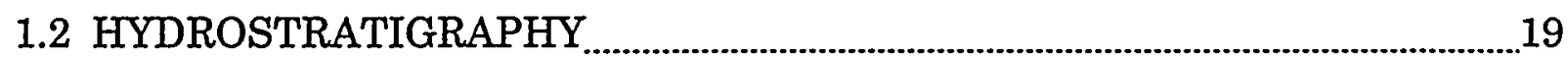

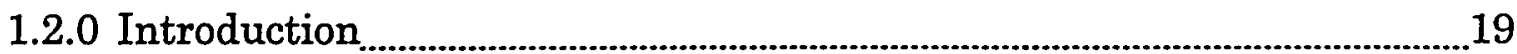

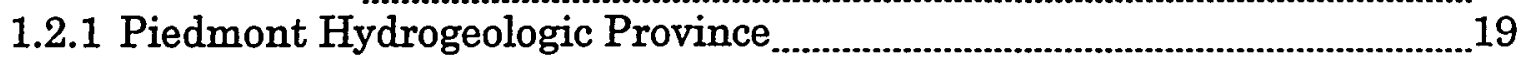

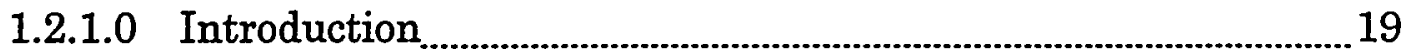

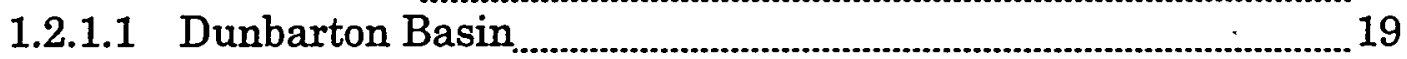

1.2.2 Southeastern Coastal Plain Hydrogeologic Province ....................................20

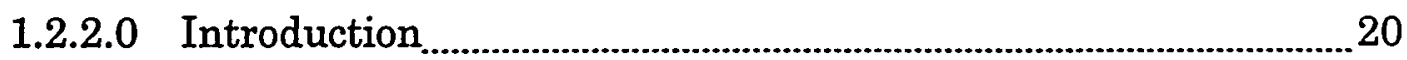

1.2.2.1 Aquifer Systems of the Southeastern Coastal Plain _...................21

1.2.2.1.0 Introduction $\quad 21$

1.2.2.1.1 Midville Aquifer System _..............................................21

1.2.2.1.2 Dublin Aquifer System …............................................25

1.2.2.1.3 Dublin-Midville Aquifer System ...................................27

1.2.2.1.4 Floridan Aquifer System ……..................................... 32

1.2.2.1.5 Floridan-Midville Aquifer System _.............................. 37 
1.2.2.2 Confining Systems of the Southeastern Coastal Plain

1.2.2.2.0 Introduction 40

1.2.2.2.1 Appleton Confining System

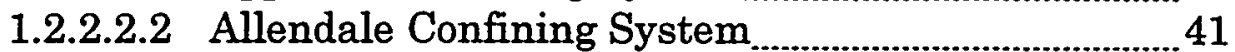

1.2.2.2.3 Meyers Branch Confining System .................................... 41

1.3 SUBSURFACE HYDROGEOLGY ẢND GEOCHEMISTRY. 43

1.3.1 Groundwater Flow. .43

1.3.1.1 Piedmont Hydrogeologic Province 43

1.3.1.2 Groundwater Flow in the Atlantic Coastal Plain 45

1.3.2 Aquifer Characteristics 55

1.3.2.1 Piedmont Hydrogeologic Province. 55

1.3.2.2 Southeastern Coastal Plain Hydrogeologic Province. 56

1.3.2.2.1 Aquifer Systems of the Southeastern Coastal Plain 56

1.3.2.2.2 Confining Systems of the Southeastern Coastal Plain

1.3.2.3 Unsaturated (Vadose) Zone Groundwater Flow 69

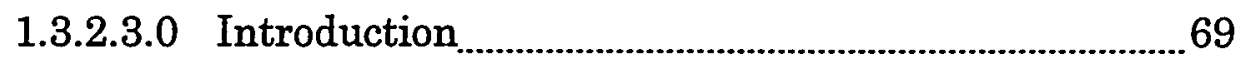

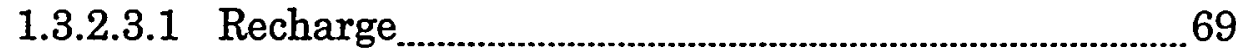

1.3.2.3.2 Direction of Groundwater Flow in the Vadose Zone 70

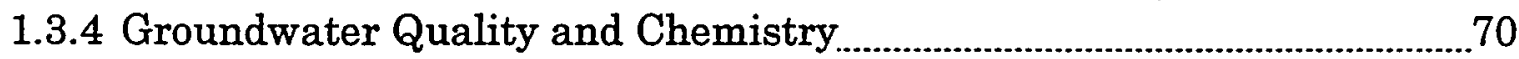

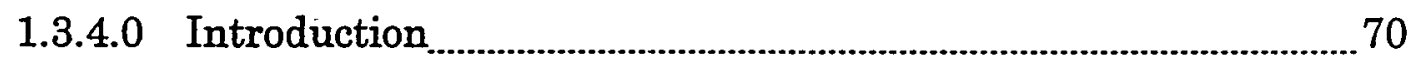

1.3.4.1 Groundwater Quality in the Atlantic Coastal Plain ......................71

GROUNDWATER MANAGEMENT

2.0 INTRODUCTION

2.1 GROUNDWATER USE

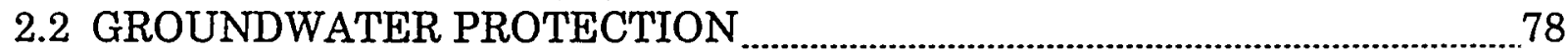

2.2.1 Groundwater Regulations

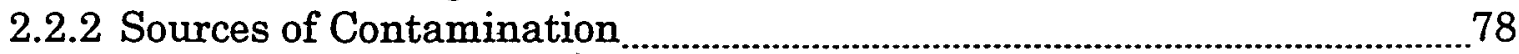




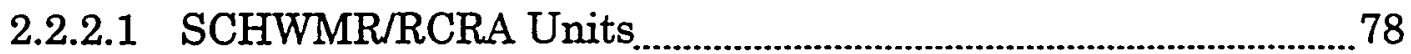

2.2.2.2 Nonhazardous Permitted Units .................................................... 80

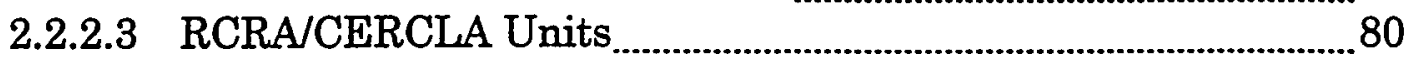

2.2.3 Aquifer Vulnerability Mapping $\quad 80$

2.2.4 Maintenance of Natural Head Differences $\quad 81$

2.3 GROUNDWATER MONITORING PROGRAM

2.3.1 Organization

2.3.2 Well Siting, Construction, Maintenance \& Abandonment ..........................81

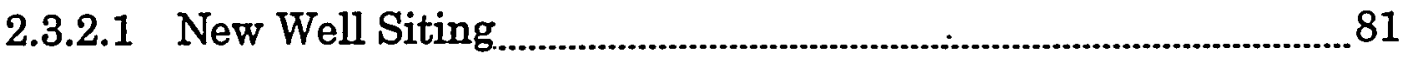

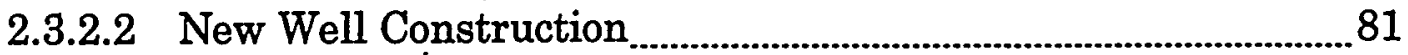

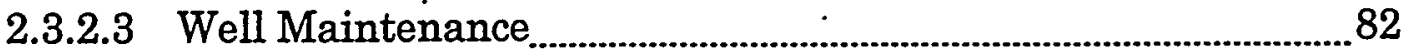

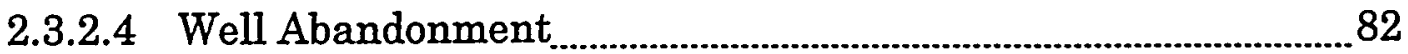

2.3.3 Sampling

2.3.3.1 Sample Planning................................................................................ 82

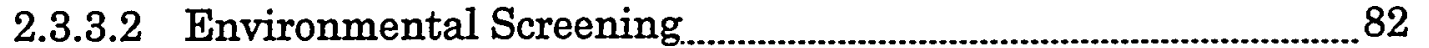

2.3.3.3 Compliance Monitoring ……........................................................... 82

2.3.3.4 Groundwater Investigation

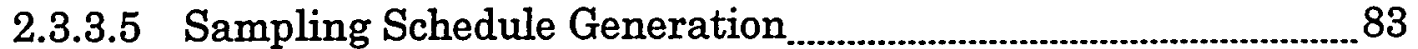

2.3.3.6 Sample Collection and Field Measurements .................................. 83

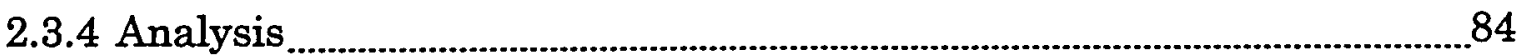

2.3.4.1 Laboratories

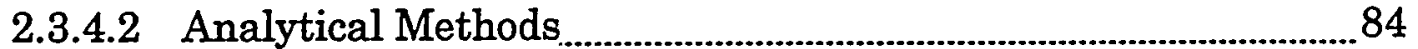

2.3.4.3 WSRC Quality Control Samples ................................................... 85

2.3.4.4 Laboratory Quality Control Samples ......................................... 85

2.3.4.5 EPD/EMS Laboratory........................................................................

2.3.5 Data

2.3.5.1 Data Collection

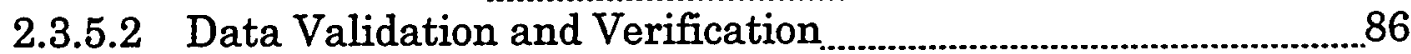

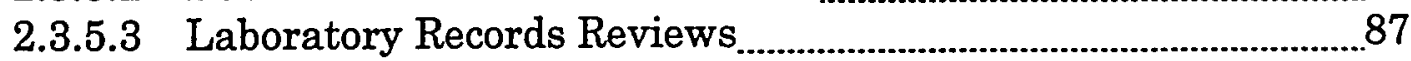

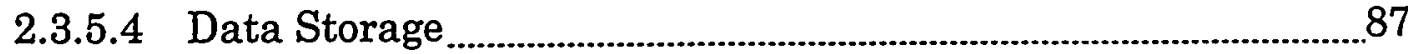

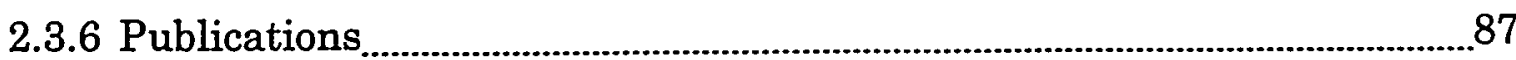


2.4 SAMPLE OPTIMIZATION

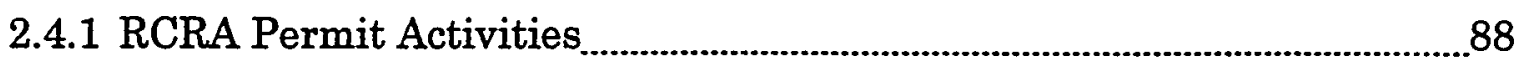

2.4.2 RFI/RI Program

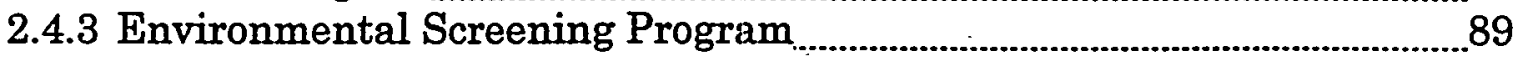

2.5 GROUNDWATER REMEDIATION

2.5.1 M-Area HWMF ............................................................ 89

2.5.2 Metallurgical Laboratory HWMF.......................................... 89

2.5.3 H-Area HWMF............................................................... 90

2.5.4 F-Area HWMF............................................................... 90

2.5.5 TNX Groundwater....................................................... 90

2.5.6 Other Units............................................................. 90

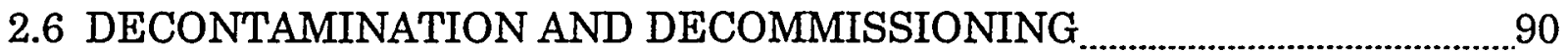

REFERENCES CITED 


\section{LIST OF FIGURES}

Figure 1-1 Generalized map of physiographic provinces of the eastern United

States

Figure 1-2 Location of the study area and physiography of the surrounding region

Figure 1-3 Structure contour map of the pre-Cretaceous basement surface near SRS

Figure 1-4 Regional physiographic-geologic-tectonic map of the southern Appalachians

Figure 1-5 Triassic-Jurassic rift basins of eastern North America

Figure 1-6 Structure within Dunbarton Basin based on seismic reflection and gravity survey at SRS

Figure 1-7 Stratigraphic cross section of the SRS region

Figure 1-8 Stratigraphic column for the SRS

Figure 1-9 Location of well clusters in and around SRS

Figure 1-10 Map showing regional extent of Southeastern Coastal Plain Hydrogeologic Province

Figure 1-11 Generalized hydrostratigraphic cross section of the SRS region.

Figure 1-12 Relation among hydrogeologic units differentiated by the Southeastern Coastal Plain, Gulf Coast, Floridan, and North Atlantic Coastal Plain regional aquifer system analysis studies

Figure 1-13 Comparison of lithostratigraphic and hydrostratigraphic units in the SRS region

Figure 1-14 Map showing the up-dip limits of the confining systems and the extent of aquifer systems in the SRS region.

Figure 1-15 Isopach map of the Midville Aquifer System/McQueen Branch Aquifer Unit 
Figure 1-16 Isopach map of the Dublin Aquifer System/ Crouch Branch Aquifer Unit

Figure 1-17 Hydrostratigraphic column for the A/M Area ................................................31

Figure 1-18 Isopach map of the Gordon Aquifer Unit ....................................................35

Figure 1-19 Isopach map of the Upper Three Runs and Steed Pond Aquifer Units

Figure 1-20 Isopach map of the Appleton Confining System 42

Figure 1-21 Potentiometric map for the crystalline metamorphic bedrock 45

Figure 1-22 Potentiometric map for the McQueen Branch Aquifer beneath the Savannah River Site

Figure 1-23 Potentiometric map for the Crouch Branch Aquifer beneath the Savannah River Site

Figure 1-24 Hydraulic head differences between the Crouch Branch and Gordon Aquifer.

Figure 1-25 Potentiometric map of the Gordon Aquifer beneath the Savannah River Site.

Figure 1-26 Water table map for the Savannah River Site

Figure 1-27 Hydraulic head differences between the Upper Three Runs and Gordon Aquifers

Figure 1-28 Piper diagram of water samples from the Floridan-Midville Aquifer System in the northern part of the Savannah River Site

Figure 1-29 Piper diagram of water samples from the Floridan Aquifer System at the Savannah River Site

Figure 1-30 Piper diagram of water samples from the Dublin-Midville Aquifer System at the Savannah River Site 


\section{LIST OF TABLES}

Table 1-1 Hydrostratigraphic Nomenclature 19

Table 1-2 Hydrostrtigraphic Data for the McQueen Branch and Crouch Branch Aquifers (modified from Aadland et al 1992). 57 
The Savannah River Site's Groundwater Protection Management Plan is intended to satisfy the requirements of DOE Order 5400.1. This revision of the plan is lengthier than previous ones because it contains information previously presented in the Water Resource Management Program, the Contaminated Groundwater Management Program, the Groundwater Monitoring Program and the

Sample Optimization Plan. It was decided that a single document would be a more efficient tool for presenting this material. Publication of the other documents will be discontinued.

The first half of this document is a fairly detailed presentation of site geology and hydrogeology. This section is intended to be a reference suitable for use by anyone engaged in groundwater work at the site. Those engaged in intense research may require more information than is presented here, but it is hoped that the references cited can be of help in directing them to that additional material.

.The second half of the plan describes the site programs that manage water use, protection and remediation. The reader will not be able to find the details of every program at every facility, but he should be able to find out what site specific documents contains those details.

It is hoped that this document will be a useful reference for those engaged in groundwater protection and management. No document could provide all of the information available about SRS's groundwater programs, but this document does present a great deal of detail while still addressing the larger issues.

\section{GEOLOGY AND HYDROGEOLOGY}

\subsection{STRATIGRAPHY}

\subsubsection{Regional Setting}

The Savannah River Site (SRS) is located along the Savannah River in west-central South Carolina. The site is in the Atlantic Coastal Plain physiographic province approximately $40 \mathrm{~km}$ (25 miles) southwest of the Piedmont province (Figure 1-1). The coastal plain is underlain by a seawarddipping wedge of unconsolidated and semi-consolidated sediments. This wedge extends from the contact at the Fall Line with the exposed metamorphic and igneous bedrock, which characterizes the Piedmont province, out, to the edge of the continental shelf. The wedge thickens from zero at the Fall Line to greater than $1200 \mathrm{~m}(4000 \mathrm{ft})$ at the South Carolina coast.

Colquhoun and Johnson (1968) divided the South Carolina Coastal Plain into three physiographic belts: the Upper, Middle, and Lower Coastal Plains (Figure 1-2). The Upper Coastal Plain slopes from a maximum elevation of $195 \mathrm{~m}(650 \mathrm{ft})$ at the Fall Line to about $85 \mathrm{~m}(250 \mathrm{ft})$ on its southeastern boundary. The Orangeburg Scarp separates the Upper and Middle Coastal Plains. The scarp has approximately $30 \mathrm{~m}(100 \mathrm{ft})$ of relief over: a distance of a few miles. The Surry Scarp divides the Middle and Lower Coastal Plain belts. Cooke (1936) divided the Upper Coastal Plain of South Carolina into the Aiken Plateau, where SRS is located (Figure 1-2), and the Congaree Sand Hills.

The Aiken Plateau is bounded by the Savannah and Congaree Rivers and extends from the Fall Line to the Orangeburg Scarp. The plateau surface is characterized by broad inter-fluvial areas with narrow, steep-sided valleys. Local relief is as much as $90 \mathrm{~m}$ (300 ft) (Siple 1967). The plateau is usually well-drained, although many poorly drained sinks and depressions exist, especially in topographically high areas [above $250 \mathrm{ft}$ mean sea level (msl)]. The Aiken Plateau also contains elliptical depressions called Carolina bays. These features are common throughout the Atlantic Coastal Plain, but are most numerous in North and South Carolina. 
GROUNDWATER PROTECTION

WSRC-TR-99-00350

MANAGEMENT PROGRAM

PAGE 2

Sediments of the Atlantic Coastal Plain were laid down during a series of transgressions and regressions of the sea. The character of the sediments indicates depositional environments ranging from fluvial, too deltaic, to shallow marine.

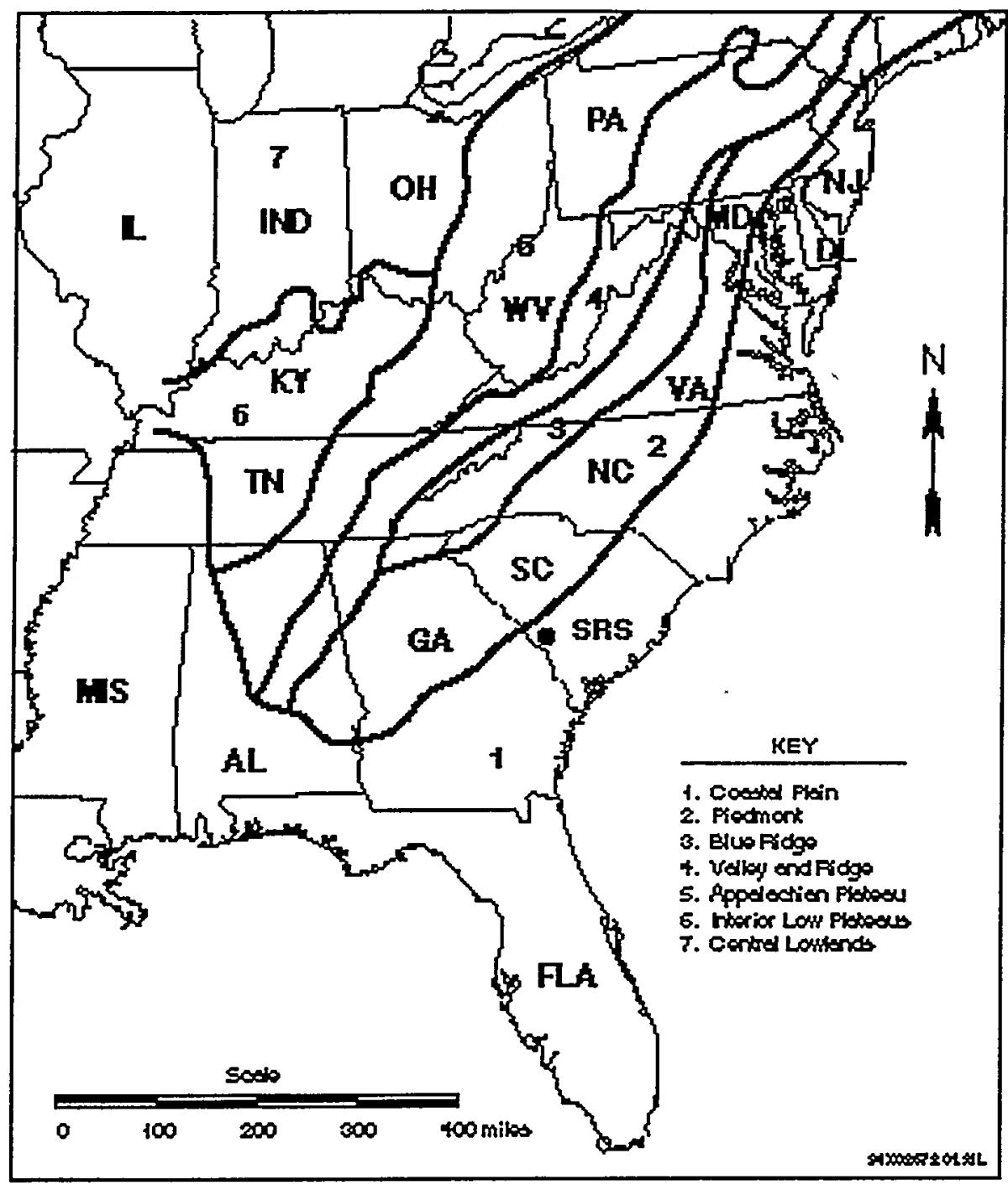

Figure 1-1. Generalized map of physiographic provinces of eastern United States (Aadland et al. 1992) 


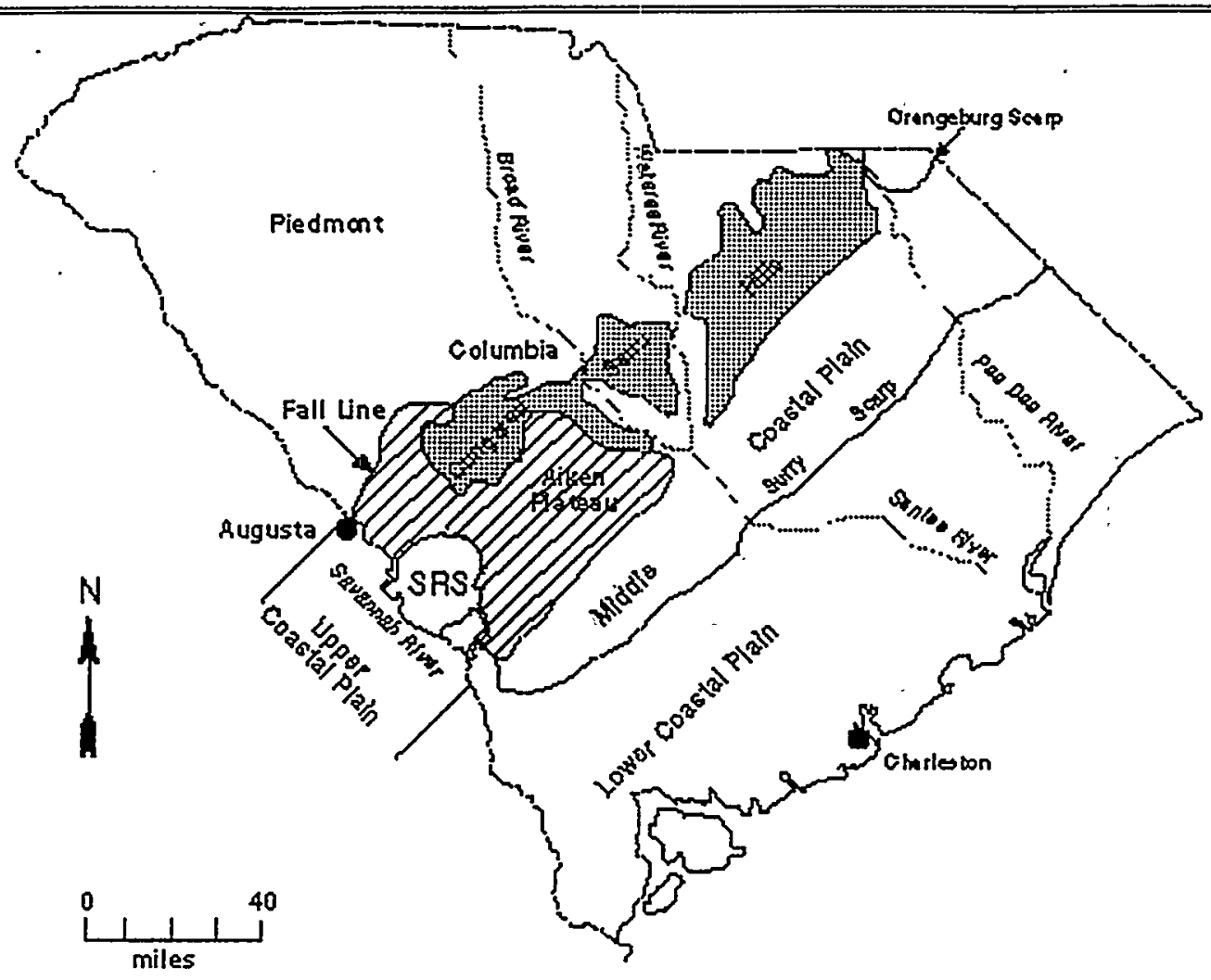

$0 \times 03672.05 .21 \mathrm{~L}$

Figure 1-2. Location of the study area and physiography of the surrounding region (Aadland et al. 1992)

\subsubsection{Basement Geology}

\subsubsection{Introduction}

The site region within a $330-\mathrm{km}$ (200-mile) radius of SRS includes parts of the physiographic provinces of the Atlantic Coastal Plain, Piedmont, Blue Ridge, and Valley and Ridge physiographic provinces (Figure 1-1). The Valley and Ridge province consists of a thrust-faulted and folded section of metasedimentary rocks and is characterized by a series of parallel ridges and valleys that have resulted from differential erosion of the sedimentary layers. To the east, the Blue Ridge province consists of a folded, faulted, and metamorphosed basement/cover sequence. The Piedmont province is the eastern-most physiographic/geologic province of the Appalachian Mountains and consists of gneiss, schist, phyllite, and slate that have been intruded by plutonic rocks of granitic to ultramafic composition. In general, the metamorphic grade increases toward the west.

Two different basement geologic terrains underlie the Coastal Plain sedimentary sequence at SRS. Basement rocks located in the northern and eastern portions of SRS consist of Precambrian to late Paleozoic, crystalline, metamorphosed sedimentary and igneous rock that are tentatively correlated to the Piedmont province. Basement rocks located in the southern and eastern portions of SRS consist of Triassic-Jurassic terrigenous and lacustrine sediments and mafic intrusive rocks that fill the Dunbarton Basin (Marine 1974; Marine and Siple 1974) (Figure 1-3). 


\subsubsection{Piedmont Province}

The Piedmont province consists of northeast-trending tectonic belts that are defined on the basis of tectonic history, metamorphic grade and structural relationships (Figure 1-4). Piedmont rocks directly underlie the sedimentary sequence of the Atlantic Coastal Plain (Daniels 1974; Popenoe and Zeitz 1977; Chowns and Williams 1983). The Piedmont province was cut by a series of rift basins' generated during the separation of North America and Africa.

The Piedmont province in northwestern South Carolina consists of variably deformed and metamorphosed igneous and sedimentary rocks ranging in age from Middle Proterozoic to Permian (1100-265 Ma). The province is subdivided into seven distinctive tectonostratigraphic belts, separated by major faults (e.g., Towaliga fault), contrasts in metamorphic grade, or both. From northwest to southeast, these are the Chauga, Inner Piedmont, Kings Mountain, Charlotte, Carolina Slate, Kiokee, and Belair belts (Figure 1-4). These metamorphic belts extend beneath the Coastal Plain sediments in central and eastern South Carolina.

The crystalline basement beneath SRS consists of Precambrian/Paleozoic metamorphic and igneous rocks that are similar to those found in the Kiokee and Carolina Slate belts of the Piedmont, based on well and geophysical data (Figure 1-3) (Marine and Siple 1974). Cores collected from wells drilled at SRS that penetrated crystalline basement rocks suggest that the crystalline basement rocks consist of gneiss, schist, granitic quartzite, and metamorphosed volcanic rock, including tuff, rhyolite, andesite, and breccia.

\subsubsection{Regional Geology of the Triassic-Jurassic Rift Basins}

Extensional faults associated with Triassic-Jurassic age basins cut the crystalline basement of the Piedmont province (Figure 1-5). Sediments within the basins consist mainly of non-marine sandstone, conglomerate, siltstone, and shale, which are referred to collectively as the Newark Supergroup. Generally, the basins are elongated in a northeast-southwest direction and are bounded by extensional faults on one or both sides. Southeast of the Fall Line, Triassic-Jurassic basins underlie the Atlantic Coastal Plain and offshore regions (Figure 1-5). 


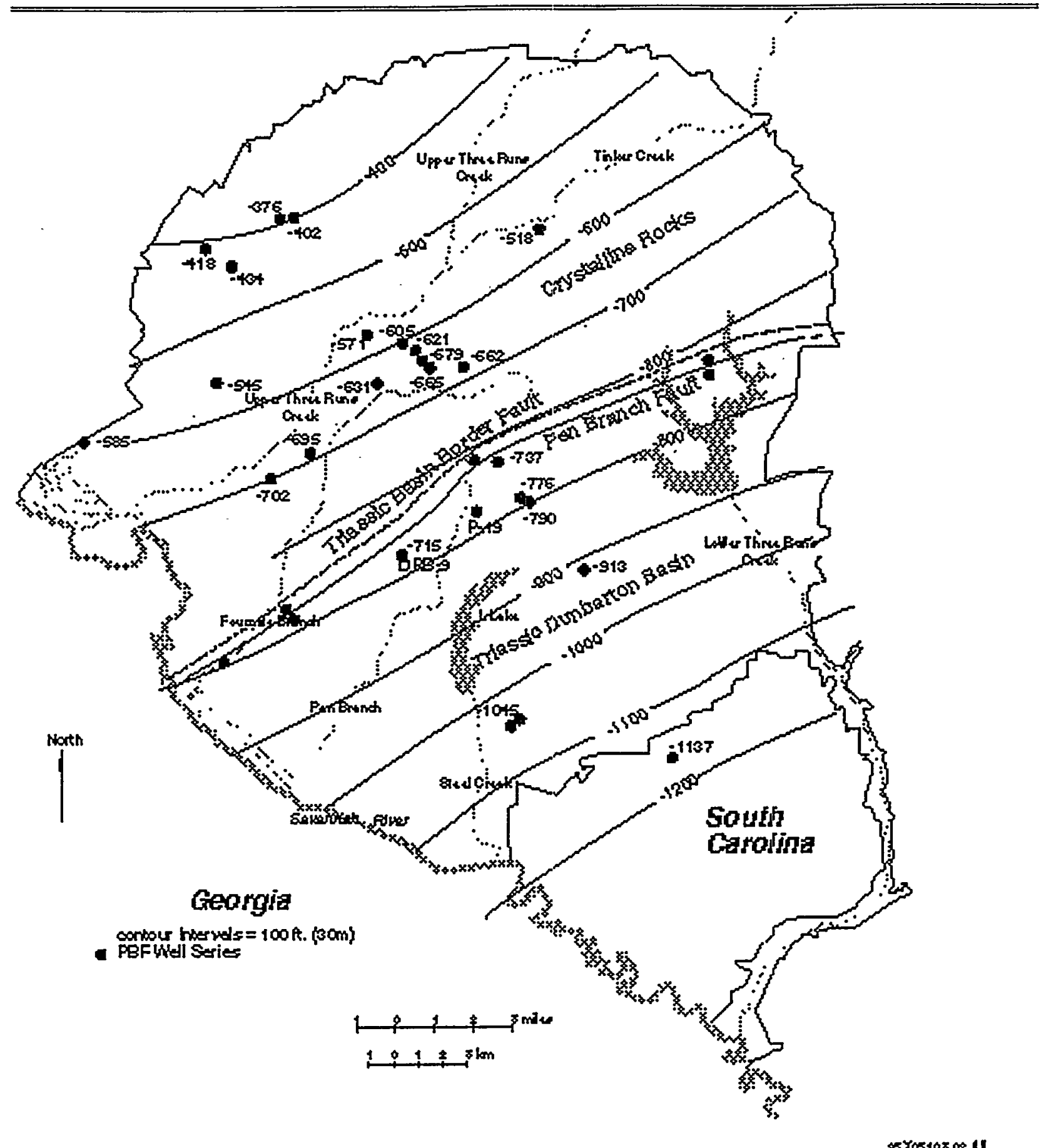

Figure 1-3. Contour map of the pre-Cretaceous basement surface near SRS (Marine and Spile 1974) 


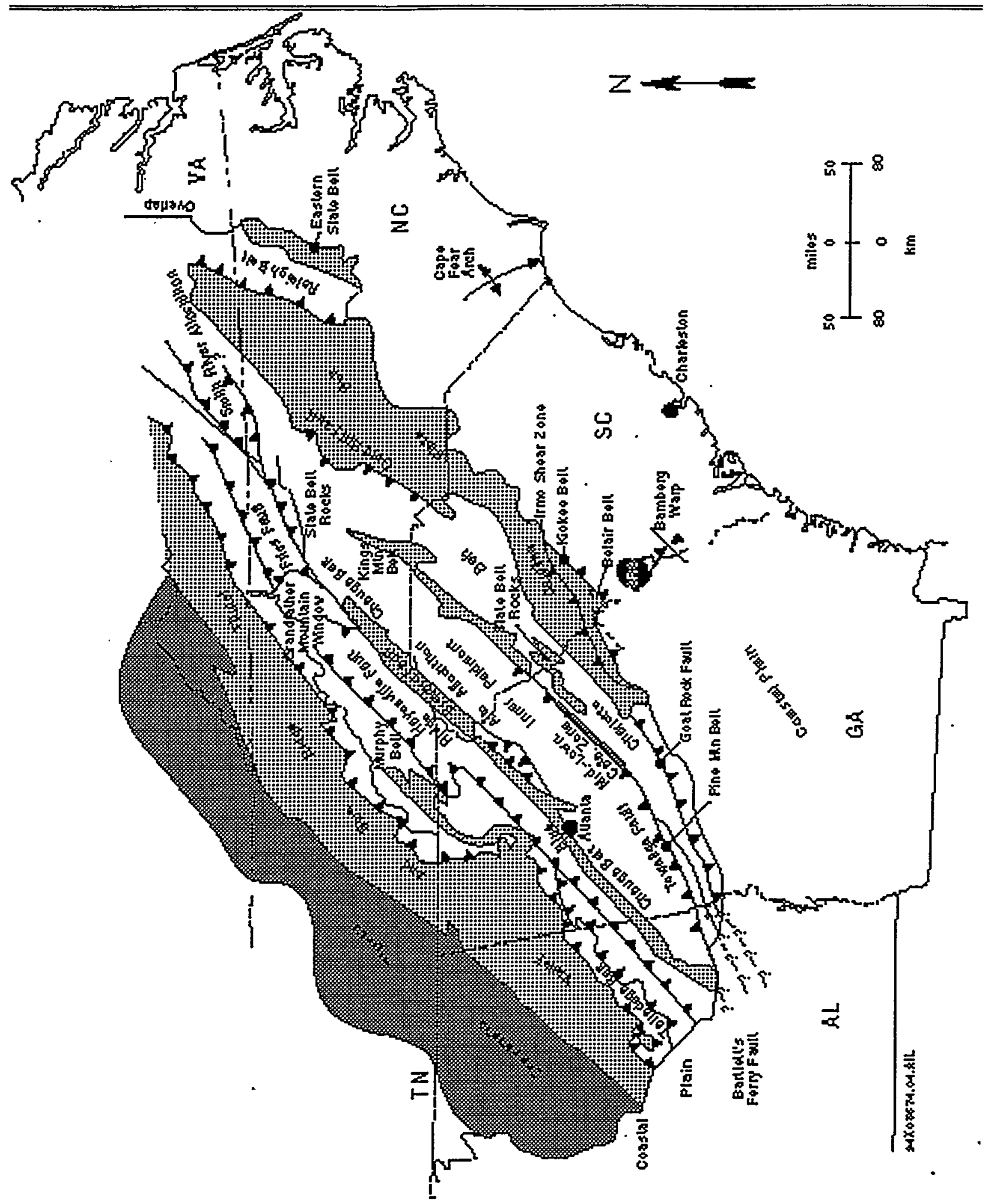

Figure 1-4. Regional physiographic-geologic-tectonic map of the southern Appalachians (Aadland et al. 1992) 


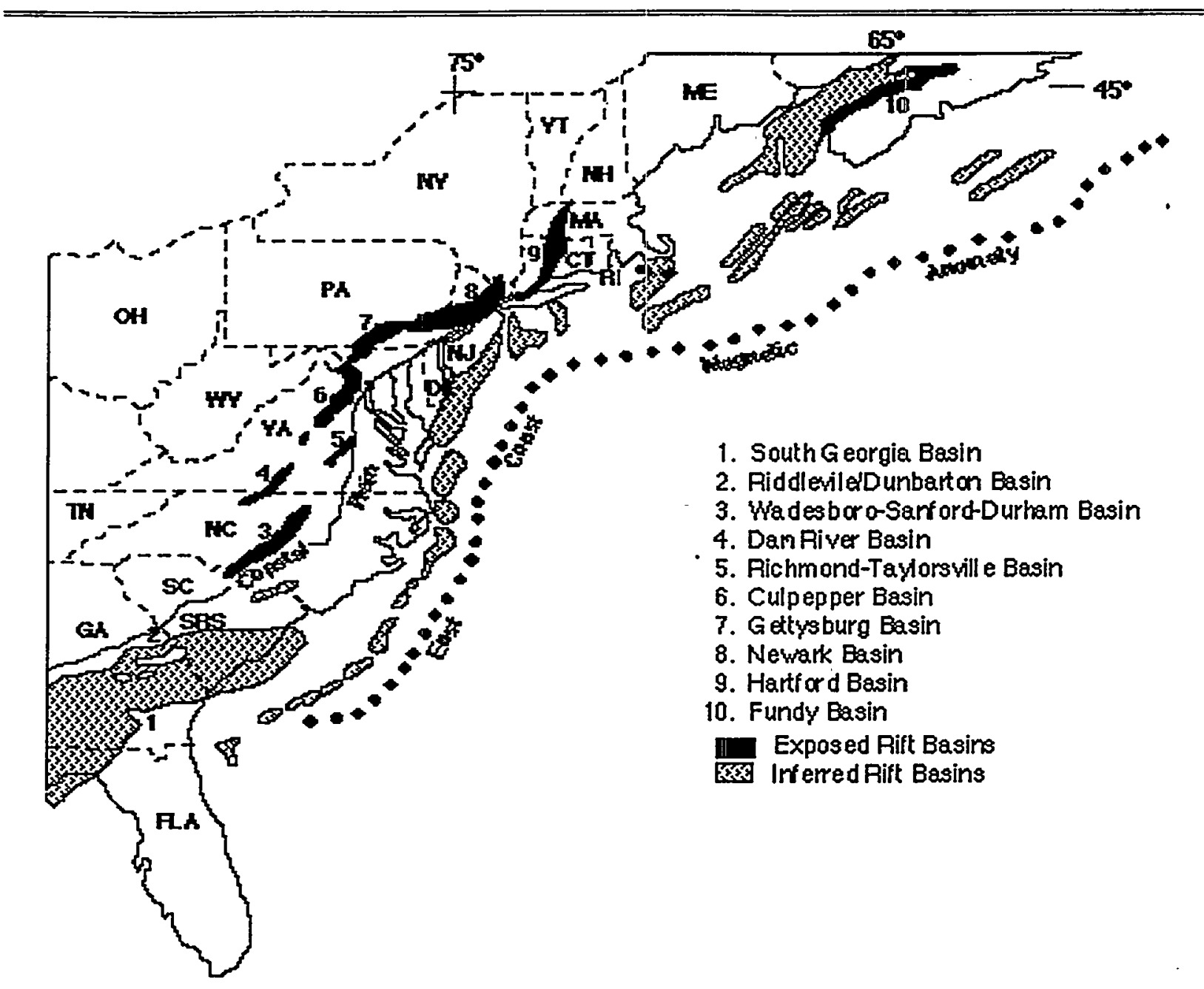

$94008672.08 .2 \mathrm{LL}$

Sex\&RE:F.R.Heck, 'Mesozoic Extension in the Southern Appalachians", pp $711-714$ in G eology, volume 17, August 1989.

Figure 1-5. Triassic-Jurassic rift basins of eastern North America (Heck 1989)

A Triassic-Jurassic rift basin, called the Dunbarton basin, lies beneath Coastal Plain cover in the southeastern part of SRS (Figure 1-6). The axis of the basin strikes north $63^{\circ}$ east, which is parallel to the regional strike of crystalline basement (Figure 1-6) (Marine and Siple 1974). The basin extends $15 \mathrm{~km}$ (25 miles) to the northeast of SRS and terminates abruptly about $8 \mathrm{~km}$ (5 miles) southwest of the Savannah River (Figure 1-6) (Siple 1967; Marine 1974). 


\subsubsection{Coastal Plain Sediments}

\subsubsection{Introduction}

Both the Paleozoic and Triassic basement rocks have been beveled by erosion and are unconformably overlain by unconsolidated to semi-consolidated Coastal Plain sediments (Colquhoun and Johnson 1968; Siple 1967; Cooke 1936). This erosional surface (Figure 1-3) dips approximately $6.6 \mathrm{~m} / \mathrm{km}$ (35 $\mathrm{ft} / \mathrm{mi}$ ) to the southeast (Colquhoun and Johnson 1968). The overlying Coastal Plain sediments form a clastic wedge that thickens and dips toward the southeast (Figure 1-7). Near the mouth of the Savannah River, this wedge is $1200 \mathrm{~m}$ (4000 ft) thick and thins northwest toward the Fall Line where it pinches out completely.

The Coastal Plain sequence near the center of SRS consists of about $167 \mathrm{~m}(550 \mathrm{ft})$ of upper Cretaceous quartz sand, pebbly sand, and kaolinitic clay, overlain by about $18 \mathrm{~m}(60 \mathrm{ft})$ of Paleocene clayey and silty quartz sand, glauconitic sand, and silt. The Paleocene beds are in turn overlain by about $91 \mathrm{~m}(300 \mathrm{ft}$ ) of Eocene sediments which grade from quartz, sand, glauconitic quartz sand, clay, and limestone into calcareous sand, silt, and clay. The calcareous strata are common in the upper part of the Eocene section in down-dip parts of SRS. Two zones of bioclastic limestone are present in the Eocene strata. They appear to be lens-like bodies that pinch out laterally into sand or clay facies. In places, especially at higher elevations, the sequence is capped by deposits of pebbly, clayey sand, conglomerate, and clay of probable Miocene age. Lateral and vertical facies changes over relatively short distances are characteristic of most of the Coastal Plain sequence. The lithologic descriptions below are therefore broad generalizations.

\subsubsection{Cretaceous System}

Upper Cretaceous sediments of Santonian through Maestrichtian age overlie Paleozoic crystalline rocks and lower Mesozoic sedimentary rocks throughout SRS. The Upper Cretaceous sequence includes the basal Cape Fear Formation and the overlying Lumbee Group, which is divided into three formations (Figure 1-8). Cooke (1936) and Siple (1967) assigned the beds of the Lumbee Group to the "Tuscaloosa Formation", but the Tuscaloosa has not been traced into the SRS area from its type locality in Alabama. The section is about $167 \mathrm{~m}(550 \mathrm{ft})$ thick near the center of the site.

\section{Cape Fear Formation}

The Cape Fear Formation rests directly on a thin veneer of saprolitic bedrock. The saprolite varies from less than $1.8 \mathrm{~m}(6 \mathrm{ft})$ to more than $12 \mathrm{~m}(40 \mathrm{ft})$ in thickness and defines the surface of the crystalline basement rocks and sedimentary rocks of the Newark Supergroup. The top of the Cape Fear is present at about $-91 \mathrm{~m}(-300 \mathrm{ft}) \mathrm{msl}$ in the northern part of SRS and at about $-240 \mathrm{~m}(-800 \mathrm{ft})$ msl to the south. The Cape Fear Formation pinches out north of the site boundary. The unit thickens to more than $73 \mathrm{~m}(240 \mathrm{ft})$ near the southeastern boundary of SRS and has a maximum known thickness of about $212 \mathrm{~m}(700 \mathrm{ft}$ ) in Georgia (Prowell et al. 1985a). The top of the formation dips approximately $30 \mathrm{ft} / \mathrm{mi}$ to the southeast across SRS. Microfossil data from samples in down-dip wells at SRS are consistent with Pollen Zone V (Prowell et al. 1985b), indicating a Santonian (early Late Cretaceous) to Coniacian age for the Cape Fear Formation (Figure 1-8). 

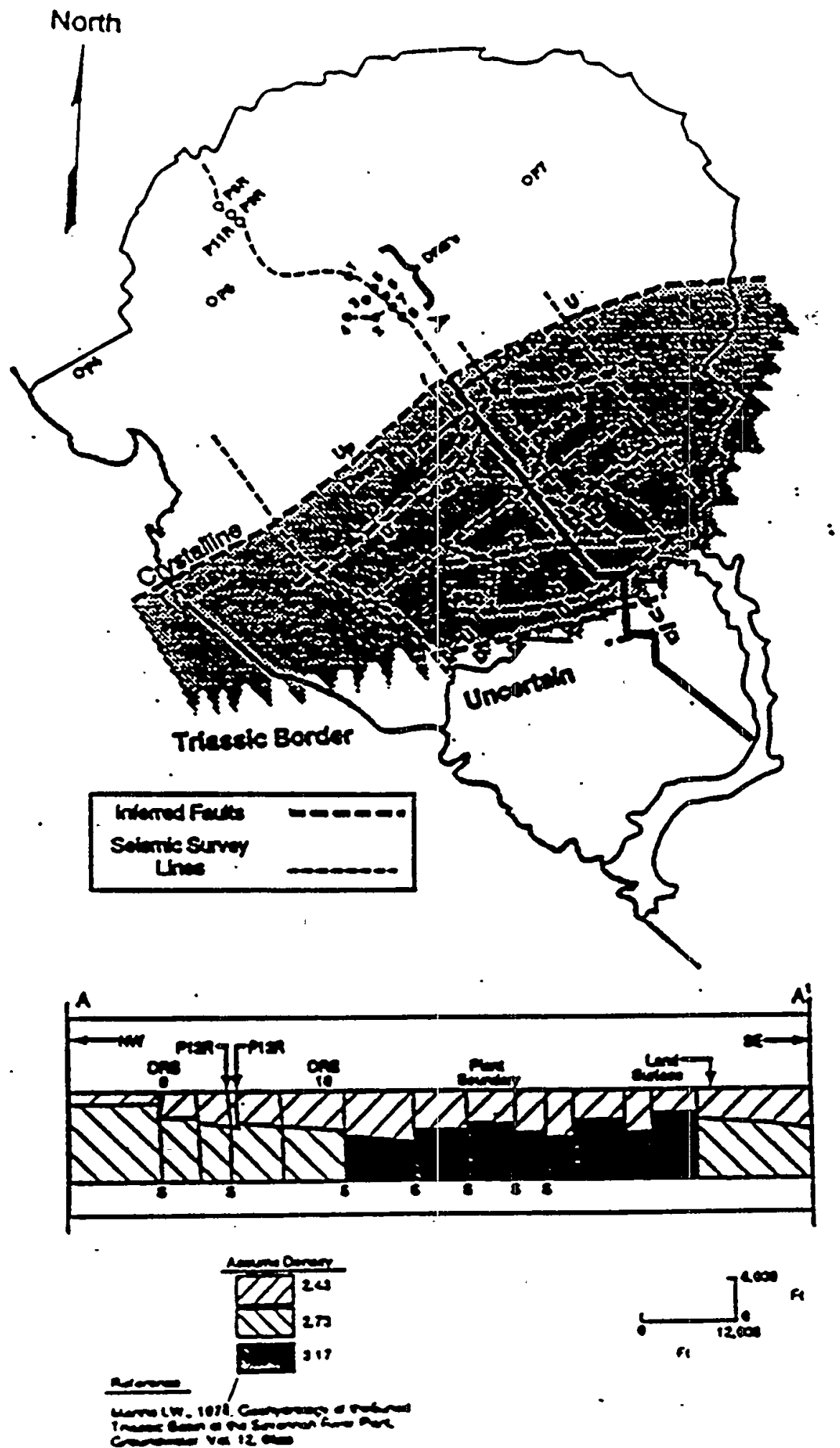

Figure 1-6. Structure within Dunbarton Basin on seismic reflection and gravity survey at SRS 


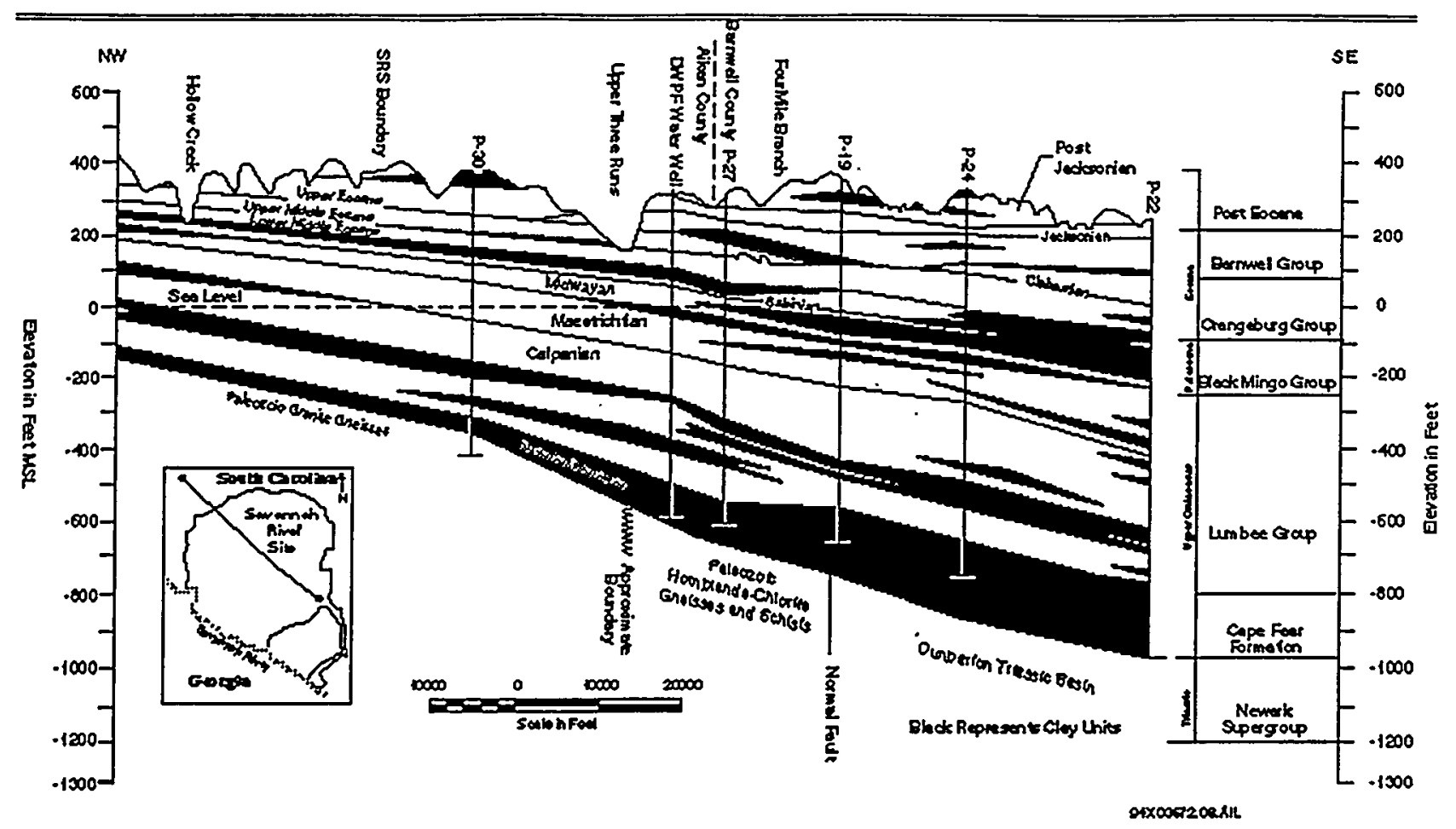

Figure 1-7. Stratigraph cross section of the SRS region (Aadland et al. 1992) 
GROUNDWATER PROTECTION

WSRC-TR-99-00350

MANAGEMENT PROGRAM

PAGE 11

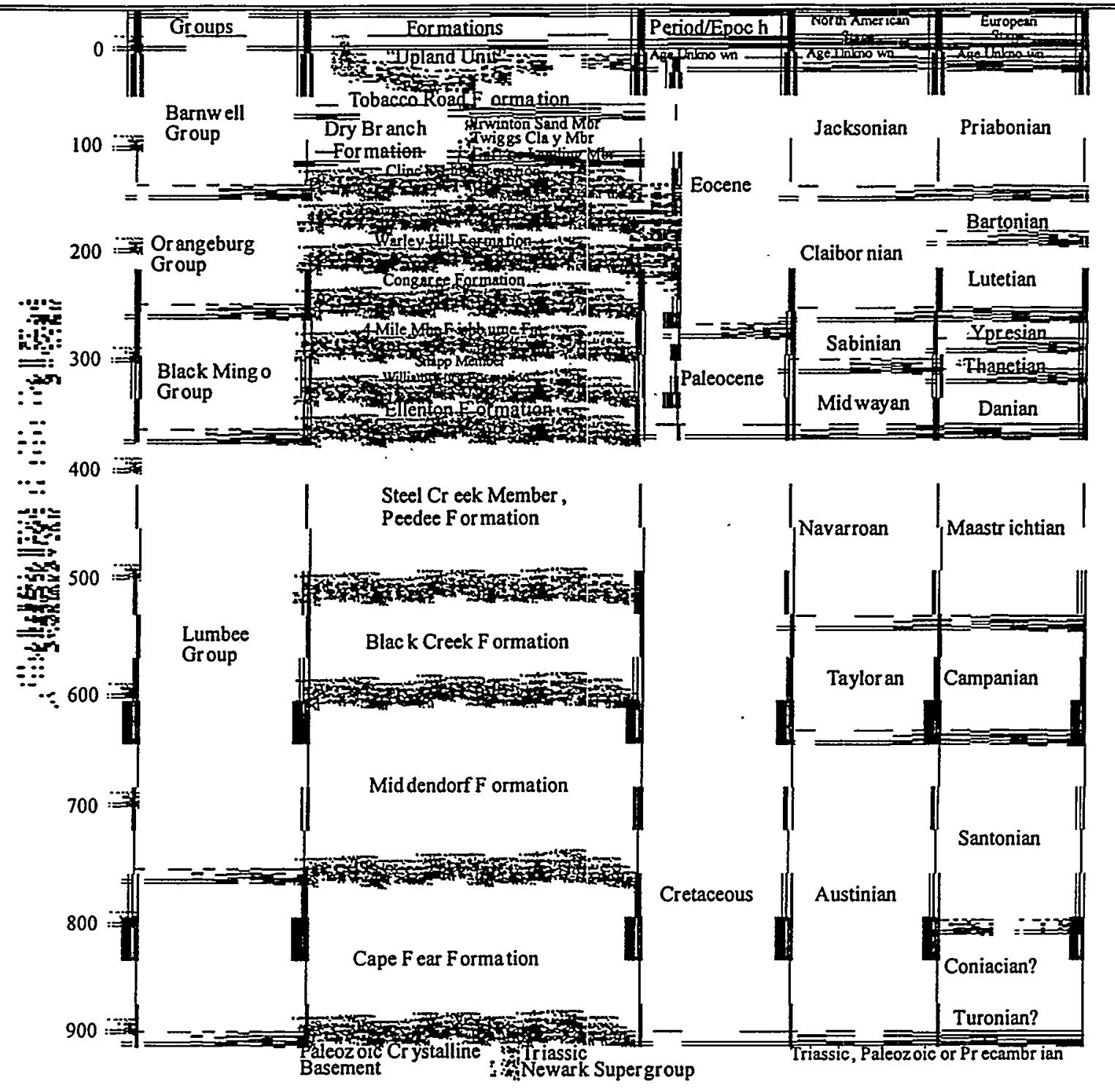

Figure 1-8. Stratigraphic column for the SRS (Aadland et al. 1992) 
The Cape Fear Formation consists of firm to indurated, variably colored, poorly sorted, silty, clayey sands and sandy silts and clays. The sand grains are angular to sub-angular, fine to more typically coarse-grained with granule and pebble zones common. The sands are arkosic in composition, with rock fragments common in the pebbly zones. These characteristics and the paucity of marine fossils are indicative of a high-energy environment close to a sediment source area, possibly fluvial-deltaic environments on the upper parts of a delta plain (Prowell et al. 1985a).

Lumbee Group

Three formations of the Late Cretaceous Lumbee Group (Swift and Heron 1969) are present in the SRS area (Faye and Prowell 1982). These are from oldest too youngest the Middendorf, Black Creek, and Peedee Formations (Figure 1-8).

The Lumbee Group consists of fluvial and deltaic quartz sands, pebbly sands, and clays in the SRS area. The sedimentary sequence is more clayey and fine-grained down-dip from the SRS area, reflecting shallow to deep marine shelf sedimentary environments. Thickness varies from about 106 $\mathrm{m}(350 \mathrm{ft})$ near the northwestern boundary of SRS to about $230 \mathrm{~m}(750 \mathrm{ft})$ near the C-10 well south of the site (Figure 1-9). The dip of the upper surface of the Lumbee Group is to the southeast at approximately $4.0 \mathrm{~m} / \mathrm{km}$ (21 ft/mi) across SRS (Figure $1-7)$.

\section{Middendorf Formation}

The Middendorf Formation overlies the Cape Fear Formation with a sharp, distinct contact. This formation was first named by Sloan (1908), but Cooke (1936) assigned these sediments to the Tuscaloosa Formation. Swift and Heron (1969) resumed use of the name Middendorf. The formation is marked by an abrupt change from the moderately indurated clays and clayey sands of the underlying Cape Fear to the slightly indurated sands and lesser clayey sands of the Middendorf. The basal zone is often pebbly. The formation thickness ranges from approximately $45 \mathrm{~m}(150 \mathrm{ft})$ in the north to $53 \mathrm{~m}(175 \mathrm{ft})$ in the south. The top of the formation dips to the southeast at about $4.9 \mathrm{~m} / \mathrm{km}$ $(26 \mathrm{ft} / \mathrm{mi}$ ) across SRS. Pollen samples from clay zones in the unit are characteristic of Pollen Zone $V$, indicating a Santonian (early Late Cretaceous) age for the unit (Christopher 1982). Regional studies by Prowell et al. (1985á) also suggest a Santonian age for the unit. The sands of the Middendorf Formation are medium- to very coarse-grained, typically angular, slightly silty, and tan and light gray to yellow in color.

\section{Black Creek Formation}

Sloan (1908) first described the Black Creek Formation as "Black Creek Shales" which cropped out in Darlington and Florence Counties. Swift and Heron (1969) assigned it formational status. Sediments assigned to the Black Creek Formation in SRS yield Campanian (middle Late Cretaceous) to Maestrichtian (late Late Cretaceous) paleontological ages and unconformably overlie the Middendorf Formation (Logan and Euler 1989).

The unit varies in thickness from approximately $77 \mathrm{~m}(255 \mathrm{ft})$ in the north to $106 \mathrm{~m}(350 \mathrm{ft})$ in the south, and dips approximately $4.2 \mathrm{~m} / \mathrm{km}(22 \mathrm{ft} / \mathrm{mi})$ to the southeast. The Black Creek is distinguished from the overlying and underlying Cretaceous units by its uniform fine-grained siltysands and relatively high clay content. It is generally darker and more lignitic and micaceous than the other Cretaceous units, especially in the up-dip part of the section. The Black Creek is composed of two thick, fining-upward sequences, each capped by thick clay beds.

Peedee Formation - Steel Creek Member 
The Maestrichtian-aged Peedee Formation was named by Ruffin (1843) in his description of beds cropping out along the Peedee River in Florence County, South Carolina. Because there is a considerable difference in lithology between the type Peedee (Heron 1958) and the sediments in the SRS region, Peedee-equivalent sediments in SRS are referred to as the "Steel Creek Member of the Peedee Formation". The formation dips approximately $3.8 \mathrm{~m} / \mathrm{km}(20 \mathrm{ft} / \mathrm{mi})$ to the southeast (Figure $1-7)$.

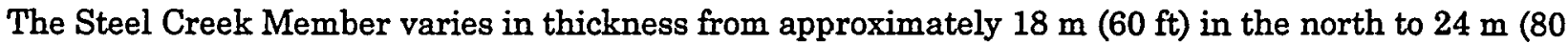
$\mathrm{ft}$ ) at well P-22 in the south. This unit overlies the Black Creek Formation and is distinguished from it by a higher percentage of sand. The formation consists of yellow, tan and gray, medium to coarse, moderately sorted sand and interbedded sand and variegated clay. The lower part of the unit consists of medium to coarse-grained, poorly to well-sorted, quartz sand, silty, sands, -and off-white to buff clay that contains thin beds of micaceous and carbonaceous clay.

\subsubsection{Tertiary System}

\section{Black Mingo Group}

In west-central South Carolina, the Black Mingo Group consists of the Midwayan (Danian-Early Thanetian/Early Paleocene) Ellenton Formation, the Early and Middle. Sabinian (Middle Thanetian/Late Paleocene) Williamsburg Formation (Colquhoun et al. 1983), and the Late Sabinian (Late Thanetian/Early Eocene) Fishburne Formation (Gohn et al. 1983) (Figure 1-8).

The Black Mingo Group consists of quartz sands, silty clays and clays that suggest upper and lower delta-plain environments of deposition generally under marine influences (Prowell et al. 1985a). In the southern part of SRS, massive clay beds, often more than $15.2 \mathrm{~m}(50 \mathrm{ft})$ thick, predominate. The upper surface of the group dips to the southeast at approximately $3.0 \mathrm{~m} / \mathrm{km}(16 \mathrm{ft} / \mathrm{mi})$, and thickens from about $21 \mathrm{~m}(70 \mathrm{ft}$ ) at the northwestern site boundary to about $48.8 \mathrm{~m}(160 \mathrm{ft})$ near the southeastern boundary (Figure 1-5).

\section{Ellenton Formation}

The Ellenton Formation (Siple 1967) unconformably overlies the Cretaceous sediments and consists

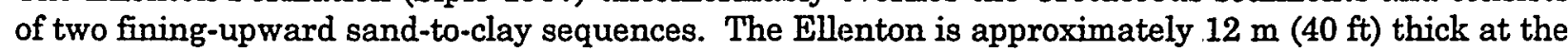
northwestern boundary of SRS and thickens to about $30 \mathrm{~m}(100 \mathrm{ft})$ near the southeastern boundary. The formation is mostly dark gray to black, moderately to poorly sorted, fine- to coarse-grained, micaceous, lignitic, silty and clayey quartz sands interbedded with dark gray clays and clayey silts. Clay and silt beds make up approximately one-third of the unit in SRS. The dark, fine-grained sediments represent lower delta plain, bay-dominated environments.

\section{Williamsburg Formation - Snapp Member}

The sediments at SRS that are time-equivalent to the Sabinian (Mid-Late Thanetian) Williamsburg Formation differ from the type Williamsburg and are designated as the "Snapp Member" of the Williamsburg Formation (Fallaw et al. 1990) (Figure 1-8). The basal contact with the underlying Ellenton Formation is probably unconformable. The Snapp Member appears to pinch out in the northwestern part of SRS and thickens to about $15 \mathrm{~m}(50 \mathrm{ft})$ near the southeastern boundary of the site.

In and near SRS, the Williamsburg sediments are typically silty, medium- to coarse-grained quartz sand interbedded with clay. These sediments suggest a lower delta-plain depositional environments. In the southern-most part of SRS, the Williamsburg consists of gray-green, fine to medium, well- 
rounded, calcareous, quartz sand and interbedded micritic limestone and limy clay that is highly fossiliferous and glauconitic (Clarke et al. 1985). This lithology suggests deposition in open shallow shelf environments somewhat removed from clastic sediment sources.

\section{Fishburne Formation - Fourmile Member}

Overlying the Williamsburg Formation is the Fourmile Member of the Fishburne Formation. The Fourmile Member averages $9 \mathrm{~m}$ (30 ft) in thickness, is mostly tan, yellow orange, brown and white, moderately to well-sorted sand, with clay beds a few feet thick present near the middle and at the top of the unit. The sands are very coarse to fine-grained, with pebbly zones common, especially near the base. Glauconite, up to about $5 \%$, is present in places, as is weathered feldspar. The glauconite and the dinoflagellate assemblages indicate that the Fourmile is a shallow marine deposit.

Overlying the Fourmile Member of the Fishburne Formation at SRS is up to $9 \mathrm{~m}(30 \mathrm{ft})$ of sand very similar to the Fourmile. These sands are better sorted, contain fewer pebbly zones, less muscovite and glauconite, and are lighter in color in many wells. Dinoflagellate assemblages indicate that the sands are correlative with the early Middle Eocene Congaree Formation. The difficulty in distinguishing the Fishburne from the Congaree Formation, has led many workers at SRS to include the entire 18-m (60-ft) section in the Congaree Formation.

\section{Orangeburg Group}

The Claibornian (Lutetian-Bartonian) Orangeburg Group consists of the lower Middle Eocene Congaree Formation, the upper Middle Eocene Warley Hill Formation, and Santee Limestone Formation. Over most of SRS, these post-Paleocene units are more marine in character than the underlying Cretaceous and Paleocene units. They consist of alternating layers of sand, limestone, marl, and clay. The group crops out at lower elevations in many places within and in the vicinity of SRS. The sediments thicken from approximately $27 \mathrm{~m}(90 \mathrm{ft})$ at the northwestern SRS boundary to about $48 \mathrm{~m}$ ( $160 \mathrm{ft})$ near the southeastern boundary. Dip of the upper surface is about $12 \mathrm{ft} / \mathrm{mi}$ to the southeast across SRS (Figure 1-7).

From the base upwards, the Orangeburg Group sequence goes from clean shoreline sands characteristic of the Congaree Formation to shelf marls, clays, sands, and limestones typical of the overlying Warley Hill Formation and Santee Limestone. The sequence is transgressive with the middle Eocene Sea reaching its most northerly position during the deposition of the Santee.

\section{Congaree Formation}

The early Middle Eocene Congaree Formation has been traced from the Congaree valley in eastcentral South Carolina into SRS, and it has been paleontologically correlated with the early Claibornian or early (and middle) Eocene Tallahatta Formation in neighboring southeastern Georgia by Fallaw et al. (1990). It is about $9 \mathrm{~m}(30 \mathrm{ft})$ thick near the center of SRS and consists of yellow, orange, tan, gray, green, and greenish gray, well-sorted, fine to coarse quartz sands with granule and small pebble zones common. The quartz grains tend to be better rounded than those in the rest of the stratigraphic column. The sediments suggest deposition in shoreline to shallow shelf environments. To the south, the Congaree Formation grades into the platform carbonate facies of the lower Santee Limestone (Colquhoun et al. 1983).

Warley Hill Formation

Unconformably overlying the Congaree Formation are approximately $1.8-3.6 \mathrm{~m}(6-12 \mathrm{ft})$ of finegrained, often glauconitic sands and green clay beds that were previously referred to as the Warley 
Hill and Caw Caw Members, respectively, of the Santee Limestone. Both the glauconitic sand and the clay at the top of the Congaree are now assigned to the Warley Hill Formation (Fallaw et al. 1990). In the up-dip parts of SRS, near the C-2 well, the Warley Hill is apparently missing or very thin, and the overlying Santee Limestone rests unconformably on the Congaree Formation.

The Warley Hill sediments indicate shallow to deeper clastic shelf environments of deposition at SRS, generally deeper water than the underlying Congaree Formation. To the south, beyond the P21 well (Figure 1-9), the green silty sands and clays of the Warley Hill undergo a facies change to the clayey micritic limestones and limy clays typical of the overlying Santee Limestone.

\section{Santee Limestone}

The late Middle Eocene deposits overlying the Warley Hill Formation consist of moderately sorted yellow and tan sand, calcareous sands and clays, limestones, and clay of the Santee Limestone. The calcareous part of the Santee is much more abundant down-dip, sporadic in the middle of SRS, and missing to the northwest. Often "McBean Formation" and "Lisbon Formation" have been applied in the past to these sediments but the term "Santee" has priority (Sloan, 1908). The Santee Limestone is about $21 \mathrm{~m}(70 \mathrm{ft})$ thick near the center of SRS and the sediments indicate deposition in shallow marine environments. The Santee is made up of three members in the SRS area (Fallaw et al. 1990): the Blue Bluff Member, the McBean Member, and the Tims Branch Member (Figure 1-8).

Blue Bluff Member

The Blue Bluff Member of the Santee consists of the gray to green, laminated micritic limestone parts of the Santee. The lithology varies from gray, fissile, calcareous clay to clayey micritic limestone to very thinly layered to laminated, clayey, calcareous, silty, fine sand, with shells and hard, calcareous nodules, lenses, and layers. Blue Bluff cores are glauconitic, up to $30 \%$ in some places. This lithology suggests deposition in protected lagoonal bay environments. The Blue Bluff tends to dominate the formation in the southern part of SRS.

\section{McBean Member}

The McBean Member consists of tan to white, calcilutite, calcarenite, shelly limestone, and calcareous sand and clay. It is the dominant member of the Santee Limestone in the central part of SRS, and represents a shallow-marine shelf deposit. The carbonate content is variable, and dissolution of carbonate within the Santee has resulted in the creation of "soft zones" and/or underconsoidated sands in the Eocene section.

Soft zones are primarily recognized during drilling by the drill string sinking under its weight (or it's own weight plus that of the hammer). Loss of drilling fluid is also an indication of encountering a soft zone or underconsolidated zone.

\section{Tims Branch Member}

The Tims Branch Member consists of the siliciclastic part of the unit. The sands are fine-and medium-grained, tan, orange, and yellow, poorly to well sorted, and slightly to moderately indurated. They are slightly glauconitic in places, and suggest siliciclastic, shallow marine to shore-face depositional environments. The Tims Branch Member dominates the Santee Limestone in the northern part of SRS. 


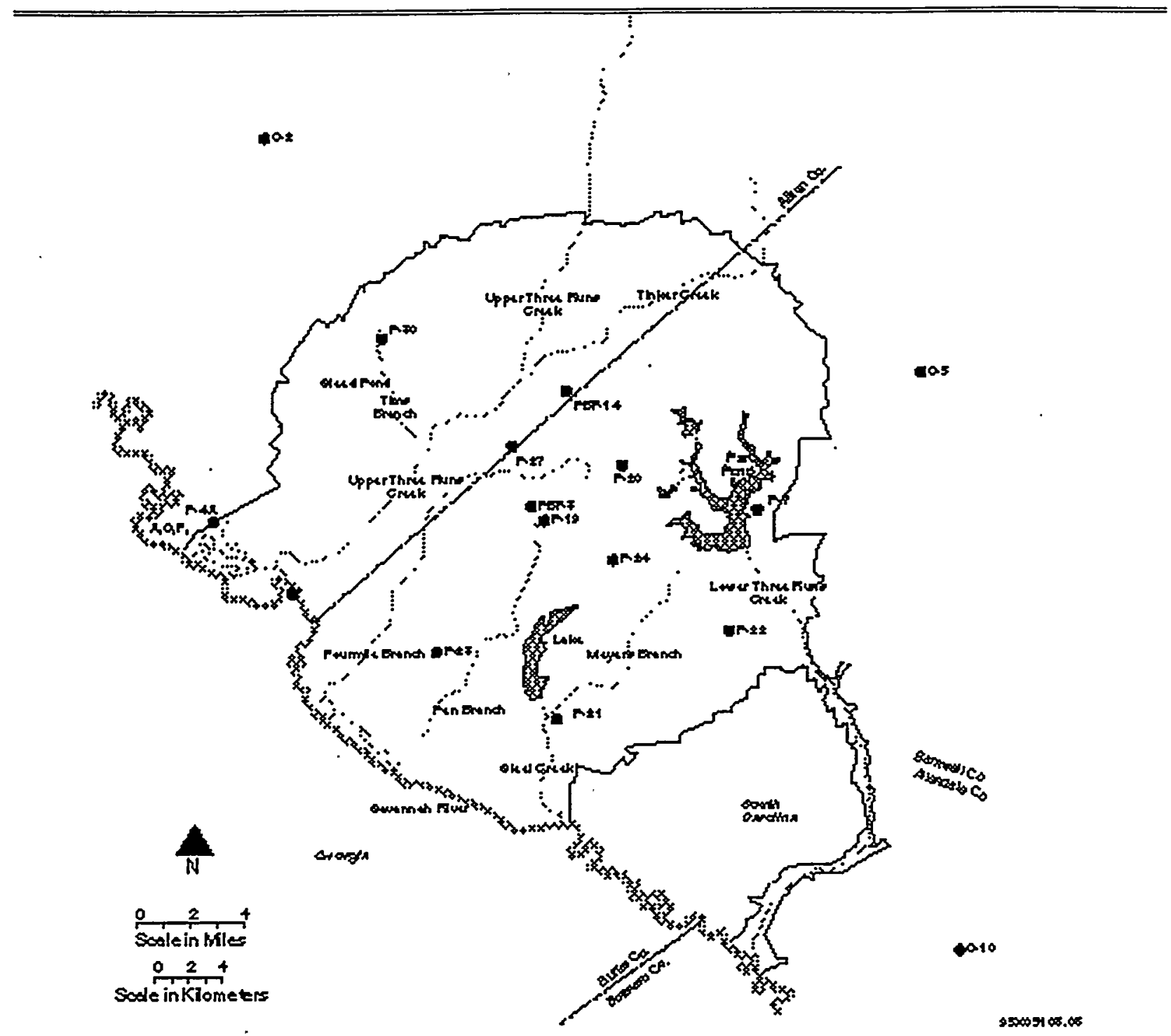

Figure 1-9. Location of wells clusters in and around SRS. Data from these wells were used to delineate the lithostratigraphy (Aadland et al. 1992)

\section{Barnwell Group}

The upper Eocene (Bartonian/Priabonian) sediments of the Barnwell Group represent the Jacksonian Stage in the Upper Coastal Plain of western South Carolina and eastern Georgia (Logan and Euler 1989). They are chronostratigraphically equivalent to the lower (late Eocene) Cooper Group of Colquhoun et al. (1983).

Barnwell Group sediments lie unconformably on the Santee Limestone (Figure 1-8), and consist mostly of shallow marine quartz sands with sporadic clay layers. The Barnwell Group includes (from oldest to youngest) the Clinchfield and Dry Branch Formations, and the Tobacco Road Sand (Figure 1-8). The group is about $36 \mathrm{~m}(120 \mathrm{ft})$ thick near the northwestern boundary of SRS and about $42 \mathrm{~m}$ $(140 \mathrm{ft}$ ) near the southeastern boundary (Figure 1-7). 
In the northern part of SRS, the Barnwell Group consists of red to brown, fine- to coarse-grained, well-sorted, massive sandy clays and clayey sands, calcareous sands and clays, and scattered thin layers of silicified fossiliferous limestone. All are suggestive of lower delta plain to shallow shelf environments.

\section{Clinchfield Formation}

The basal late Eocene Clinchfield Formation consists of light-colored quartz sands, and glauconitic, biomoldic limestones, calcareous sands, and clays. The sands constitute the Riggins Mill Member of the Clinchfield Formation, and are composed of medium to coarse, poorly to well sorted, loose and slightly indurated, tan, gray, and green quartz sand. The Clinchfield is about $7.5 \mathrm{~m}(25 \mathrm{ft})$ thick in the southeastern part of the site and pinches out or becomes unrecognizable in the center of the site. The carbonate sequence of the Clinchfield Formation constitutes the Utley Limestone Member of the formation. It is composed of sandy, glauconitic limestone and calcareous sand with an indurated, biomoldic facies being developed in places. In SRS cores, the sediments are tan and white and slightly to well-indurated.

\section{Dry Branch Formation}

The Jacksonian (late Eocene) aged Dry Branch Formation is divided into the Irwinton Sand Member, the Twiggs Clay Member, and the Griffins Landing Member. The unit is about $60 \mathrm{ft}$ thick near the center of SRS.

\section{Twiggs Clay Member}

The Twiggs Clay Member is predominant in the Dry Branch Formation west of the Ocmulgee River in Georgia. The tan, light gray, and brown clay beds, usually one to three in number, are up to $3.6 \mathrm{~m}$ (12 ft) thick in SRS wells, but are not continuous over long distances (thousands of feet). These clay beds have been informally referred to in past SRS reports as the "tan clay".

Historically, shallow wells drilled at SRS to sample the water table aquifer (Upper Three Runs Aquifer) were terminated after encountering the "first" substantial confining unit, usually the tan to brown clays in the Dry Branch Formation. It was assumed early on that the clay constituted a single, regionally significant confining layer, which was informally referred to as the "tan clay". Recent detailed lithostratigraphic analysis of drill core and down-hole geophysical data indicated that there are anywhere from zero to three or four, 6-inch to 3-ft-thick discontinuous clay beds in the stratigraphic interval which is approximately $6 \mathrm{~m}(20 \mathrm{ft})$ thick where the clays are observed. Thus, there is no single "tan clay" bed that acts as the first or shallowest regional confining unit. However, the clay beds in the Dry Branch are often locally significant, and they often divide the Upper Three Runs Aquifer into zones.

\section{Griffins Landing Member}

The Griffins Landing Member is composed mostly of tan to green, slightly to well indurated, quartzose calcareous micrite and sparite, calcareous quartz sand, and slightly calcareous clay. The unit appears to be widespread in the southeastern part of SRS, where it is about $50 \mathrm{ft}$ thick, but becomes sporadic in the center where it pinches out. The carbonate content is highly variable. In places, the unit lies unconformably on the Utley Member, which contains much more indurated, moldic limestone. In other areas it lies on the non-calcareous quartz sand of the Clinchfield. The Griffins Landing Member appears to have formed in shallow marine to lagoonal environments. 
The Irwinton Sand Member is composed of tan, yellow, and orange, moderately sorted quartz sand, with interlaminated and interbedded clays abundant in places (Twiggs Clay lithology). The Irwinton Sand crops out within the SRS. The thickness is quite variable but is about $40 \mathrm{ft}$ near the northwest site boundary and about $70 \mathrm{ft}$ near the southeastern boundary.

\section{Tobacco Road Sand}

The late Jacksonian-aged (late Late Eocene) Tobacco Road Sand consists of moderately to poorly sorted, red, brown, tan, purple, and orange fine to coarse quartz sands. Pebble layers are fairly common, as are clay laminae and beds. The sediments show characteristics of a shallow marine deposit.

\section{"Upland Unit"/Hawthorn Formation}

Deposits of very poorly sorted silty, clayey sand, pebbly sand, and conglomerate of the "upland unit" cap many of the hills at higher elevations over much of SRS. The environment of deposition appears to be fluvial, and the unit thickness changes abruptly due to both channeling of the underlying Tobacco Road Sand during "upland" deposition and subsequent erosion of the "upland" unit itself. Thicknesses of up to $60 \mathrm{ft}$ have been documented (Nystrom et al. 1986).

Lithologic types comparable to the "upland unit" but assigned to the Hawthorn Formation overlie the Barnwell Group and the Cooper Group in the southern part of SRS.

\section{Late Tertiary Dune Sands}

Unnamed dune sands unconformably overly Upland Unit sediments in many localities on teh eastern and southeastern portions of SRS. The sands are generally medium, angular, and moderately sorted quartz with minor mica content. The sands are devoid of clay and of the heavy mineral fraction that is characteristic of underlying units. Prowell (1994a) has tentatively assigned a late Miocene of Pliocene age to theses deposits.

\subsubsection{Quaternary System}

The Pliocene (?) sand dune deposits on the Aiken Plateau are the youngest units with wide lateral extent in the SRS area. Younger deposits are those associated with fluvial processes or with the formation of peat deposits in flood plains or in depressions on the surface of the plateau. 


\subsection{HYDROSTRATIGRAPHY}

\subsubsection{Introduction}

The hydrostratigraphic classification presented in this chapter is based on the recommended guidelines for the classification of hydrostratigraphic units developed by the South Carolina Hydrostratigraphic Nomenclature Subcommittee. The classification uses a hierarchy of aquifer and confining units ranked at four levels. The hierarchy is illustrated in Table 1-1 and correlated with the NASC proposed by Seaber (1987).

\section{Table 1-1 Hydrostratigraphic Nomenclature}

Two hydrogeologic provinces are recognized in the Central Savannah River Area (CSRA) subsurface (Aadland and Bledsoe 1990a, 1990b). The uppermost province, which consists of the wedge of unconsolidated Coastal Plain sediments of Late Cretaceous and Tertiary age, is referred to as the Southeastern Coastal Plain hydrogeologic province (Figures 1-10 and 1-11). The Coastal Plain hydrogeologic province is further subdivided into aquifer and confining systems; the systems are subdivided into units and zones. The underlying province, referred to as the Piedmont hydrogeologic province, includes Paleozoic metamorphic and igneous basement rocks and Triassic-aged lithified mudstone, sandstone, and conglomerate contained within the Dunbarton Basin (Figures 1-10 and 111).

\subsubsection{Piedmont Hydrogeologic Province}

\subsubsection{Introduction}

The Piedmont hydrogeologic province extends below the Southeastern Coastal Plain hydrogeologic province in the CSRA area (Figure 1-12). It consists of igneous and metamorphosed igneous and sedimentary bedrock of Precambrian and Paleozoic age and clay-rich, unconsolidated material called saprolite or regolith which is derived from in situ weathering of the underlying rock (Aller et al. 1987).

The regolith holds significant quantities of water in pore spaces between rock particles. The bedrock, on the other hand, does not have any significant intergranular porosity. Instead, its water storage capacity occurs in sheetlike fractures within the rock. The hydraulic conductivities of the regolith and the bedrock are similar, and range from about 0.001 to $1 \mathrm{~m} /$ day $(0.003$ to $3 \mathrm{ft} /$ day) (Aller et al. 1987). The major difference in their water-bearing characteristics is in their porosity; the regolith porosity ranges from about 20 to 30 percent, while the bedrock porosity ranges from about 0.01 to 2 percent (Aller et al.-1987).

\subsubsection{Dunbarton Basin}

The red consolidated mudstone of the Dunbarton Basin has also been considered part of the Piedmont hydrogeologic province in the SRS area (Aadland and Bledsoe 1990a, 1990b). The sediments were deposited in a Triassic extensional basin (Marine 1974; Marine and Siple 1974). The permeability of these rocks is very low, ranging from approximately $1 \times 10^{-6}$ to $3 \times 10^{-9} \mathrm{~m} /$ day (Marine 1974). Dissolved solids in the basin waters is nearly twice as high as in the surrounding crystalline rock (Marine and Siple 1974). 


\subsubsection{Southeastern Coastal Plain Hydrogeologic Province}

\subsubsection{Introduction}

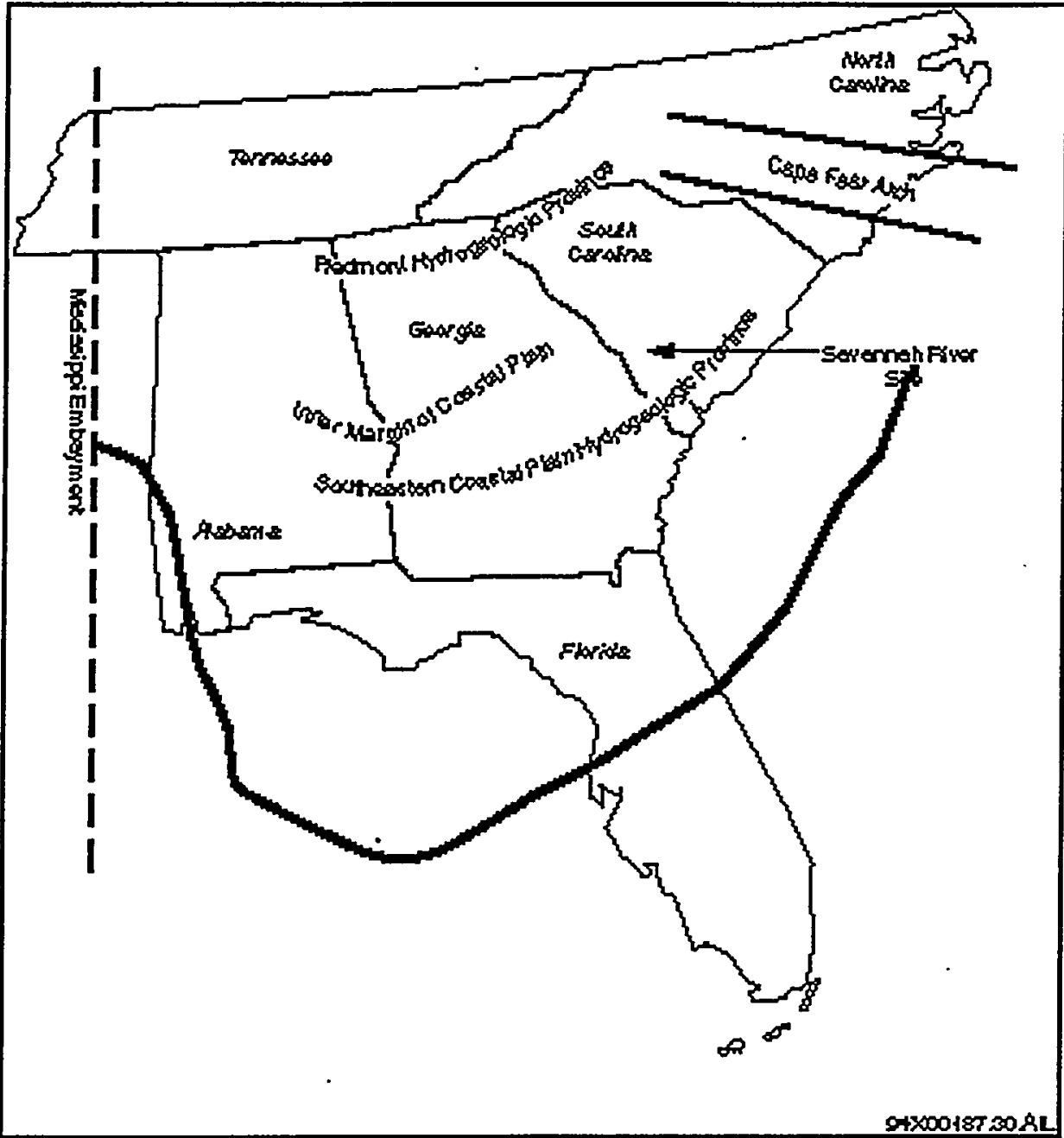

Figure 1-10. Map showing regional extent of Southeastern Coastal Plain Hydrogeologic Province (Aadland et al.1992)

The Southeastern Coastal Plain hydrogeologic province underlies approximately $307,000 \mathrm{~km} 2$ $(120,000 \mathrm{mi2})$ of the Coastal Plain of South Carolina, Georgia, Alabama, Mississippi and Florida and a small contiguous area of southeastern North Carolina (Figure 1-10). It extends from the Mississippi embayment in central Mississippi to the southwestern flank of the Cape Fear arch in southeastern North Carolina.

The Southeastern Coastal Plain hydrogeologic province grades laterally to the northeast into the Northern Atlantic Coastal Plain Aquifer System (Meisler 1980), and to the west into the Mississippi embayment and Coastal Lowlands Aquifer Systems (Grubb 1986). The northern and northwestern limits of the province are its contact with crystalline rocks at the Fall Line, which marks the updip limit of Coastal Plain sediments. The topography of the region ranges from extensive, flat, coastal 


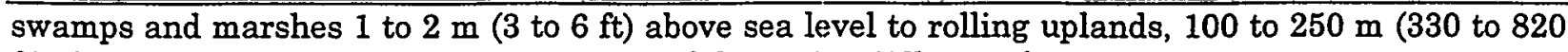
$\mathrm{ft}$ ) above sea level, along the inner margin of the region (Aller et al. 1987).

The Southeastern Coastal Plain hydrogeologic province is comprised of a multi-layered hydraulic complex of clay and marl beds which act to retard water flow interspersed with beds of sand and limestone that transmit water more readily. Ground water flow paths and flow velocity for each of these units are governed by the hydraulic properties, the geometry of the particular unit, and the distribution of recharge and discharge areas. Hydraulic conductivity in the aquifer units of the Coastal Plain range from 3 to $100 \mathrm{~m} /$ day (10 to $400 \mathrm{ft} /$ day) (Aller et al. 1987). Regional recharge rates range from 50 to $500 \mathrm{~mm} /$ year (2 to $20 \mathrm{in} /$ year) (Aller et al. 1987).

Miller and Renken (1988) divide the Southeastern Coastal Plain hydrogeologic province into seven regional hydrologic units (Figure 1-12)-four regional aquifer units separated by three regional confining units. Six of the seven hydrologic units are recognized in the CSRA and are referred to as hydrogeologic systems (Aadland and Bledsoe 1990a, 1990b).

The sediments that make up the Southeastern Coastal Plain hydrogeologic province in west-central South Carolina and east-central Georgia have been grouped into three aquifer systems divided by two confining systems, all of which are underlain by the Appleton Confining System (Figures 1-11 and 1-13). The Appleton Confining System separates the Southeastern Coastal Plain hydrogeologic province from the underlying Piedmont hydrogeologic province (Figure 1-11). Individual aquifer and confining units are delineated within each of the aquifer systems. These units are further subdivided into aquifer and confining zones. The SRS lithostratigraphy that constitutes the Southeastern Coastal Plain hydrogeologic province in the CSRA is shown with the attendant hydrostratigraphic subdivision in Figure 1-13.

\subsubsection{Aquifer Systems of the Southeastern Coastal Plain}

\subsection{Introduction}

In ascending order the aquifer systems in the study area include the Midville Aquifer System, the Dublin Aquifer System, and the Floridian Aquifer System (Figures 1-11 and 1-13). It should be noted that the Dublin and the Midville Aquifer Systems are defined and named at type well locations in Georgia (Clarke et al. 1985). The unit names have been brought into the study area to delineate correlative hydrogeologic units.

\subsection{Midville Aquifer System}

The Midville Aquifer System is present in the southern half of the study area, overlies the Appleton Confining System, and is separated from the overlying Dublin Aquifer System by the Allendale Confining System (Figures 1-11 and 1-13). The up-dip limit of the Allendale Confining System is illustrated on Figure 1-14. 


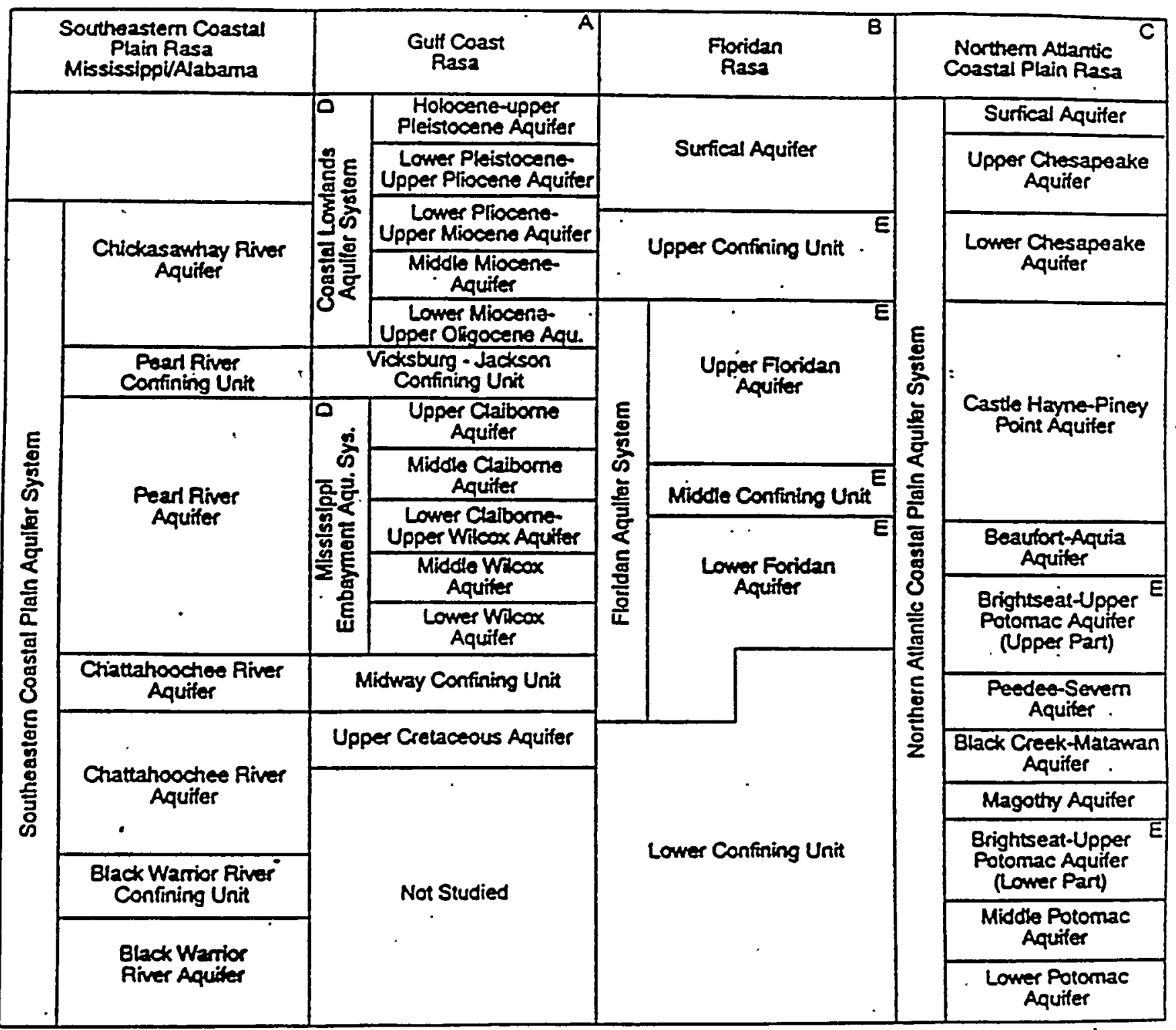

Figure 1-11. Relation among hydrogeologic units differentiated by the Southeastern Coastal Plain, Gulf Coast, Floridan, and North Atlantic Coastal Plain regional aquifer system analysis studies. (Miller and Renken 1988) 


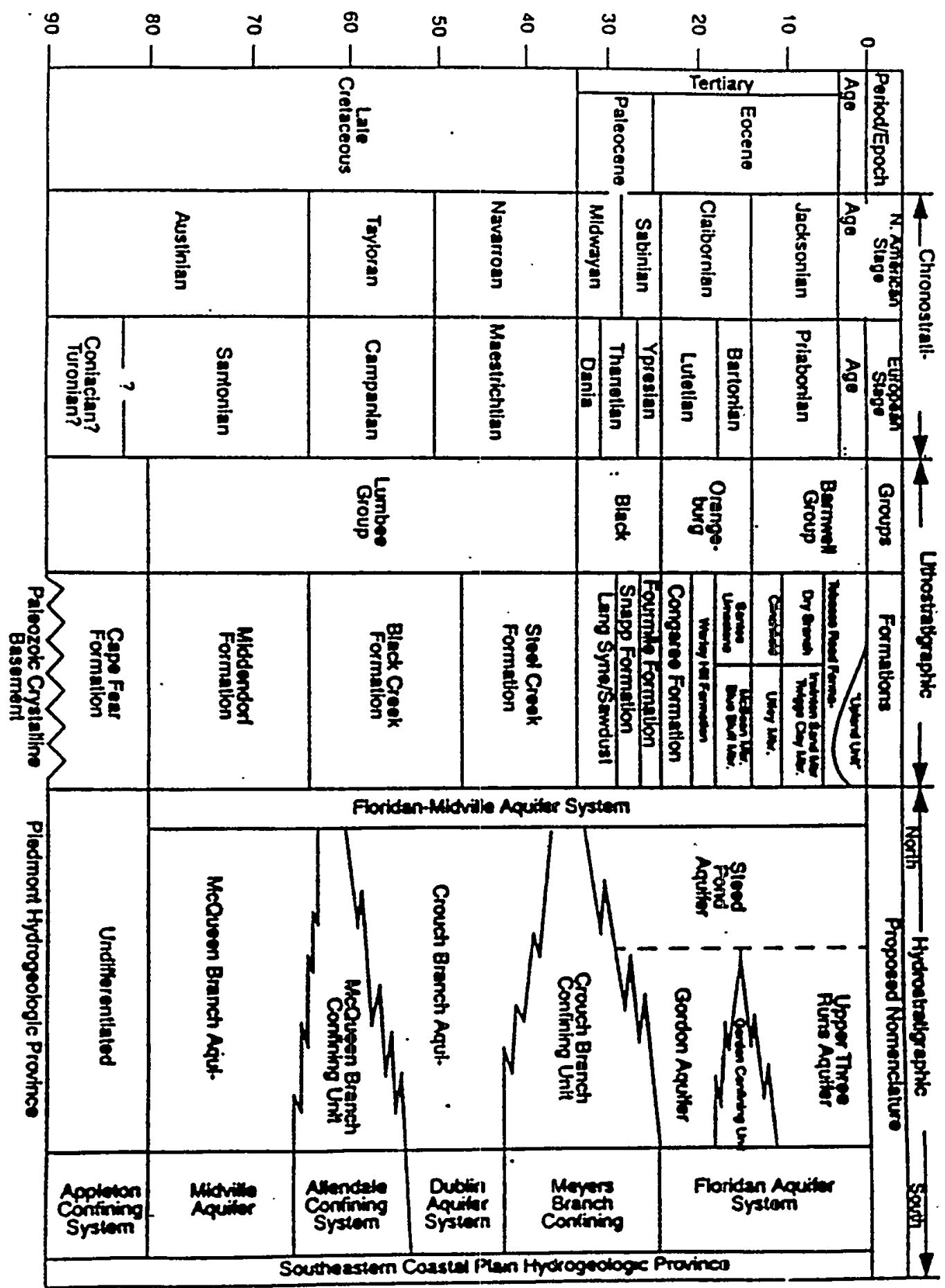

Figure 1-12. Comparison of lithostratigraphic and hydrostratigraphic units in the SRS region (Aadland et al. 1992). 


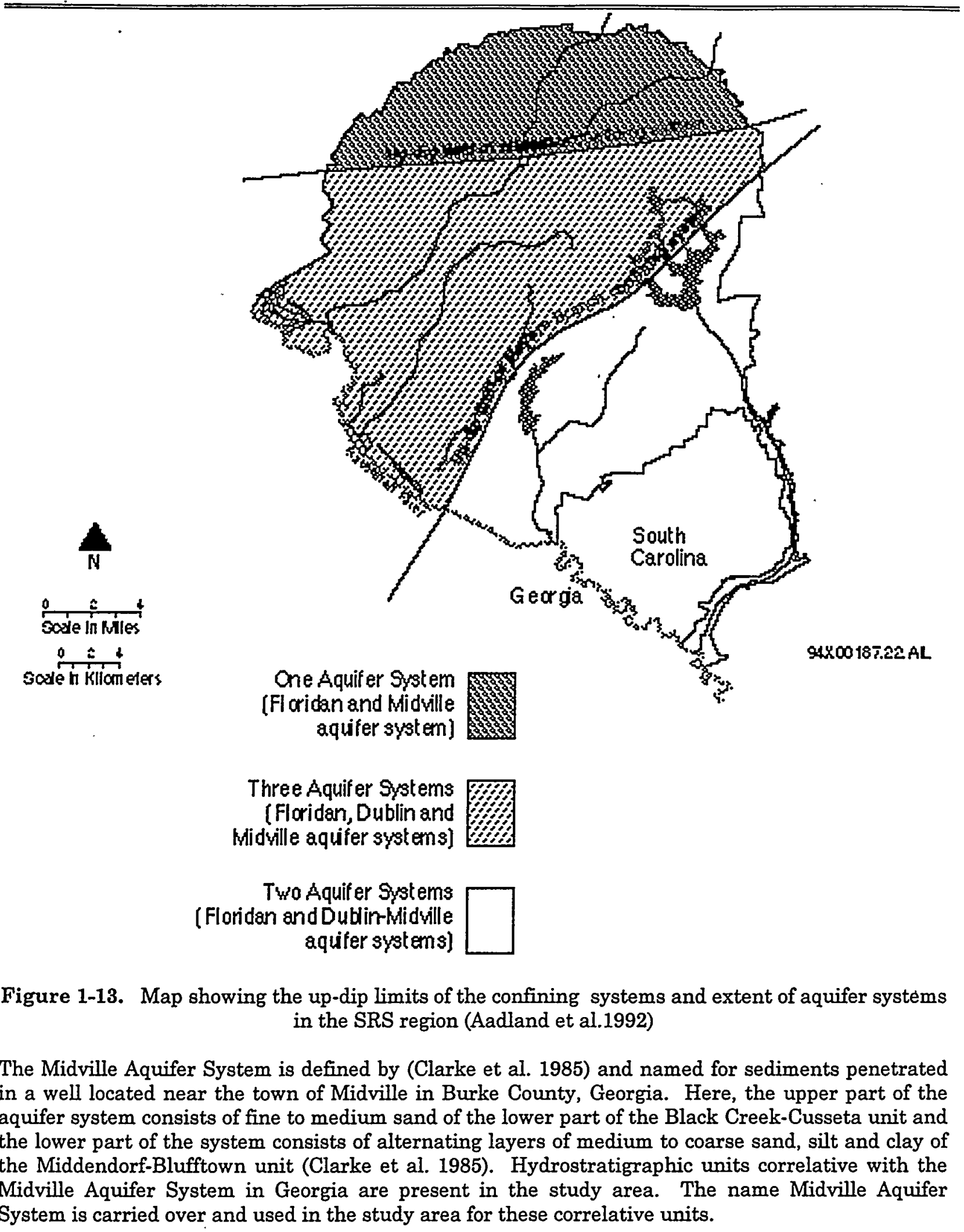


Sediments penetrated in reference well P-21 (Figure 1-9) are typical of the Midville Aquifer System in the study area. The well is located in the southeastern corner of SRS near Steel Creek. The Midville is $70.7 \mathrm{~m}$ (232 ft) thick in P-21 (Figure 1-9) with a total sand thickness of $59.7 \mathrm{~m}$ (196 ft) contained in five beds. Here, the Midville consists of the medium to very coarse-grained sands of the Middendorf Formation, and the better sorted, fine-grained often clayey sands of the lower one-third of the Black Creek Formation (Figure 1-13). The two units are usually separated by the interbedded sands and variegated clays that cap the Middendorf Formation. The clay beds are $18.0 \mathrm{~m}(59 \mathrm{ft}$ ) thick in well P-21 (Figure 1-9), but can be as much as $24.4 \mathrm{~m}(80 \mathrm{ft})$ thick elsewhere. The variegated clay beds thin but are persistent to the north, where they constitute the McQueen Branch Confining Unit that separates the McQueen Branch Aquifer from the Crouch Branch Aquifer in the up-dip Dublin-Midville Aquifer System (Figure 1-12).

In the SRS region, sediments of the Midville Aquifer System are primarily light-gray, white-to-buff, poorly sorted sand frequently interbedded with lenses of white, pink, or purple clay that were deposited in upper delta plain environments.

In the southern part of the study area, sediments within the upper part of the Cape Fear Formation become more sandy, and in the vicinity of the C-10 well cluster (Figure 1-9) appear to be hydraulically connected with the sands near the base of the overlying Middendorf Formation; these are included in the Midville Aquifer System.

The thickness of the Midville Aquifer System ranges from 70.1 to $100.6 \mathrm{~m}$ (230 to $330 \mathrm{ft}$ ) (Figure 115). The variation in the thickness of the unit is a result of the variation in thickness and persistence of clays in the overlying Allendale Confining System. The base of the aquifer system (top of the Appleton Confining System) dips at approximately $5.7 \mathrm{~m} / \mathrm{km}(30 \mathrm{ft} / \mathrm{mi})$ to the southeast across the study area, while the upper surface dips at approximately $4.7 \mathrm{~m} / \mathrm{km}(25 \mathrm{ft} / \mathrm{mi})$.

\subsection{Dublin Aquifer System}

The Dublin Aquifer System is present in the southeastern half of the study area. It is underlain by the Allendale Confining System and overlain by the Meyers Branch Confining System (Figures 1-11 and 1-13). The up-dip limit of the Dublin Aquifer System corresponds to the up-dip limit of the Allendale Confining System (Figure 1-14). North of this line, the Dublin-Midville Aquifer System is defined (Figure 1-11).

The upper part of the Dublin Aquifer System consists of fine to coarse sand and limestone of the lower Huber-Ellenton unit. Comparable stratigraphic units serve as confining beds within the study area, and are considered part of the Meyers Branch Confining System. The lower part of the Dublin Aquifer System consists of alternating layers of clayey sand and clay of the Peedee-Providence unit. Clarke et al. (1985) noted that to the east near the Savannah River, clays within the upper part of the lower Huber-Ellenton unit form a confining unit that separates an upper aquifer of Paleocene age from a lower aquifer of Late Cretaceous age. The upper aquifer of Clarke et al. (1985) is the Gordon Aquifer as defined within the study area, and their confining unit constitutes the Meyers Branch Confining System of the SRS region. 


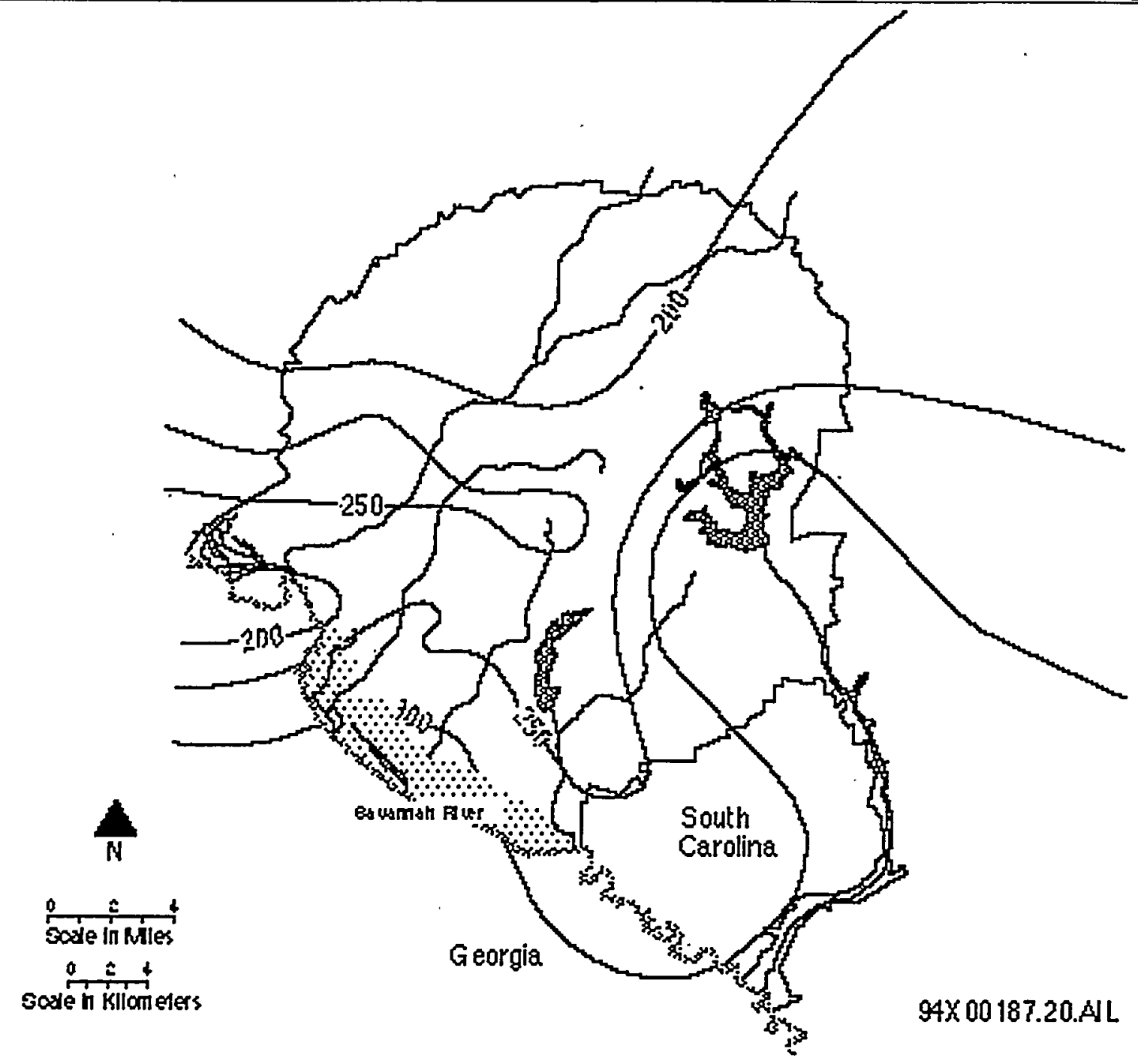

Figure 1-14. Isopach map of the Midville Aquifer System/McQueen Branch Aquifer Unit (Aadland et al. 1992)

In the study area, sediments typical of the Dublin Aquifer System are penetrated in the reference well P-22 (Figure 1-9), which is located near Lower Three Runs, in the southeastern corner of SRS. The system consists of the well-sorted sands and clayey, lignitic, and micaceous sands of the upper fining-upward sequence of the Black Creek Formation, and the medium to coarse, moderately sorted sand and interbedded sand and variegated clay of the Peedee Formation. The Dublin is overlain by clay beds that cap the Peedee Formation. These clay beds constitute the base of the Meyers Branch Confining System (Figure 1-13).

The Dublin Aquifer System is $64.9 \mathrm{~m}$ (213 ft) thick in the P-22 well (Figure 1-9). The thickness of the Dublin Aquifer System generally increases toward the south, and ranges from about $45.7 \mathrm{~m}$ (150 ft) to more than $91.4 \mathrm{~m}$ (300 ft) (Figure 1-15). Near the up-dip limit of the system, thicknesses are variable. 
The Dublin Aquifer System and its up-dip equivalent, the Crouch Branch Aquifer, are present across most of the study area and crop out parallel to the Fall Line. In the study area, transmissivity in the Crouch Branch Aquifer (up-dip equivalent of the Dublin Aquifer System) is relatively high because of the coarse sand and low clay content of the aquifer. In the southern part of the study area, where the Dublin Aquifer System is defined, and further south and east, a transition from lower delta plain to pro-delta deposition is indicated by a decrease in grain size and an increase in clay content. This results in much lower values for the hydraulic conductivity and transmissivity in the Dublin Aquifer System.

\subsection{Dublin-Midville Aquifer System}

The Dublin-Midville Aquifer System underlies the central part of SRS (Figures 1-11 and 1-13). The system is overlain by the Meyers Branch Confining System that includes the sequence of interbedded permeable and confining beds in the Paleocene-aged. Black Mingo Group, and locally, the confining beds in the uppermost part of the Peedee Formation. The Dublin-Midville is underlain by the indurated clayey silty sands and silty clays of the Appleton Confining System.

The up-dip limit of the system is established at the up-dip pinchout of the overlying Meyers Branch Confining System (Figure 1-14). Here the Dublin-iMidville coalesces with the overlying Floridian Aquifer System forming the Floridan-Midville Aquifer System. The down-dip limit of the DublinMidville is established at the up-dip limit of the Allendale Confining System. South of this line, the Dublin-Midville Aquifer System splits into the Dublin and Midville Aquifer Systems.

The Dublin-Midville Aquifer System includes two aquifer units, the McQueen Branch Aquifer and the Crouch Branch Aquifer, separated by the McQueen Branch Confining Unit (Figure 1-15). The two aquifers can be traced northward, where they continue to be an integral part of the FloridianMidville Aquifer System.

The Dublin-Midville Aquifer System.is defined for sediments penetrated in reference well P-27 that are representative of the geologic and hydrologic properties of the system. The system is $153.9 \mathrm{~m}$ $(505 \mathrm{ft}$ ) thick in the well and consists of the medium to very coarse-grained, typically angular, slightly silty sands of the Middendorf Formation and the clayey, micaceous, poorly to moderately well sorted, fine to medium sand and silty clay beds of the Black Creek and Peedee Formations. The system includes a thick clay bed at a depth of $183.8 \mathrm{~m}(603 \mathrm{ft} ;-100.3 \mathrm{~m}$ msl or $-329 \mathrm{ft} \mathrm{msl})$ to $200.6 \mathrm{~m}$ $(658 \mathrm{ft} ;-117.0 \mathrm{~m} \mathrm{msl}$ or $-384 \mathrm{ft} \mathrm{msl})$ that constitutes the McQueen Branch Confining Unit. The thickness of the Dublin-Midville Aquifer System varies from about $250 \mathrm{ft}$ to about $550 \mathrm{ft}$ (Figures 115 and 1-16). 


\section{GROUNDWATER PROTECTION}

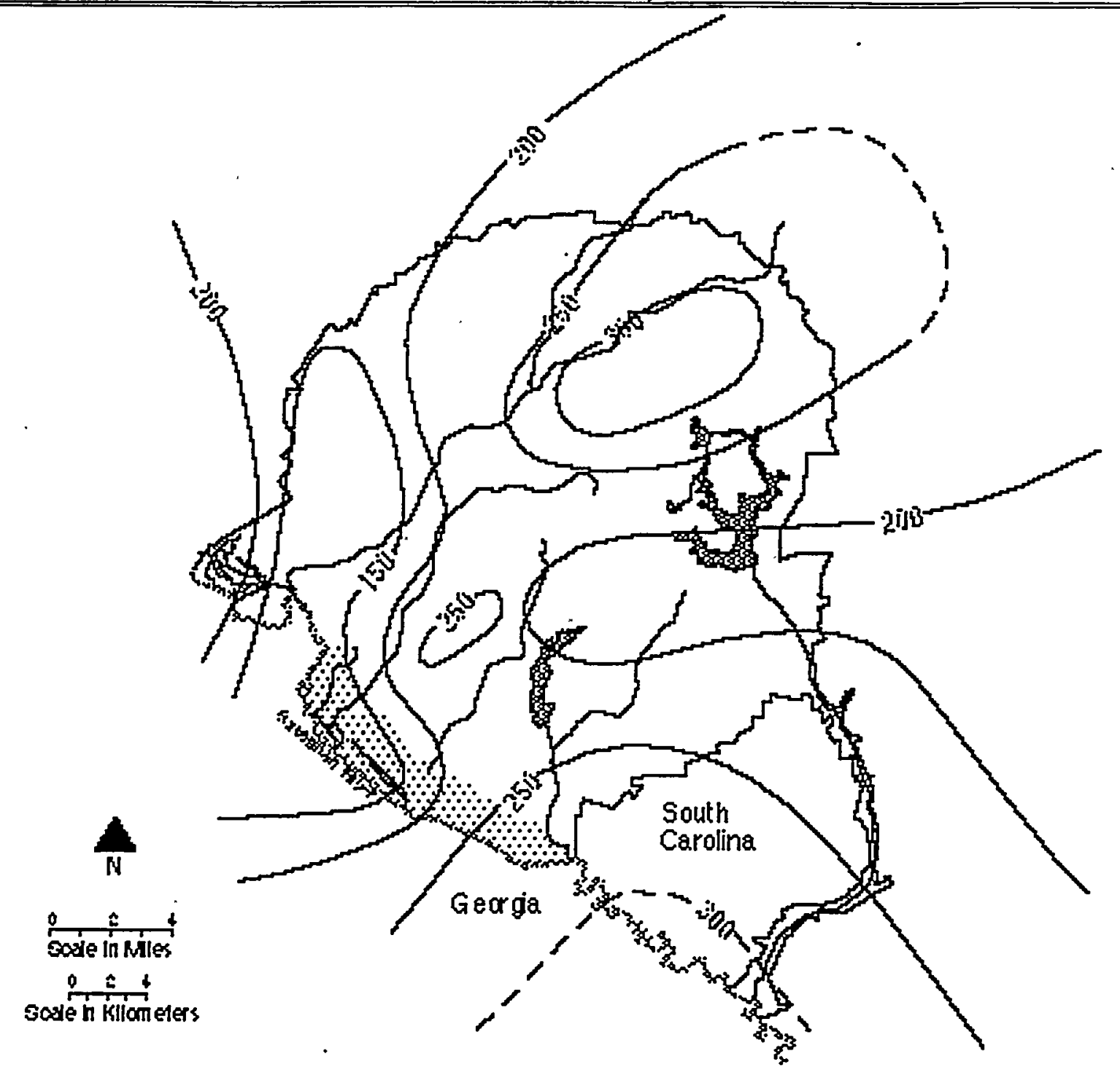

$94 \times 00187.21 . \mathrm{AL}$

Figure 1-15. Isopach map of the Midville Aquifer System/McQueen Branch Aquifer Unit (Aadland et al. 1992) 


\section{McQueen Branch Aquifer Unit}

The McQueen Branch Aquifer unit is defined for sediments penetrated in well P-27 (Figure 1-9) where the unit is $61.9 \mathrm{~m}$ (203 ft) thick. The McQueen Branch Aquifer is overlain by the McQueen Branch Confining Unit, which consists of the silty clay bed that caps the basal upward fining sequence of the Black Creek Formation; and. underlain by the Appleton Confining System. The aquifer unit is bounded to the southeast by the up-dip limit of the Allendale Confining System (Figure 1-14). South of the limit line, the McQueen Branch Aquifer becomes the Midville Aquifer System. The McQueen Branch Aquifer persists to the northwest at least as far as the C-2 well (Figure 1-9) in central Aiken County, and is an integral part of both the Dublin-Midville and the Floridian-Midville Aquifer Systems.

The McQueen Branch Aquifer consists primarily of unconsolidated, medium to very coarse-grained, angular, slightly silty sands of the Middendorf Formation, and the clayey, micaceous, poorly to moderately well-sorted, fine to medium sand and silty clay beds of the lower one-third of the Black Creek Formation. Typically a clay bed or several clay beds that cap the Middendorf Formation are present in the aquifer. The thickness of the McQueen Branch Aquifer varies from about 46 too more than $91 \mathrm{~m}$ (150 to more than $300 \mathrm{ft}$ ) in the study area. There is an overall thickening of the unit from the northwest to the southeast (Figure 1-15). The sediments of the McQueen Branch Aquifer in the study area were deposited in upper delta plain environments. McQueen Branch Aquifer sands are relatively clean.

What are referred to here as the McQueen Branch and the Crouch Branch Aquifers of the DublinMidville Aquifer System have previously been termed the "Tuscaloosa Aquifer" (Siple 1967). When the original water-level measurements were made, some of the data reflected water levels in the McQueen Branch Aquifer, some in the overlying Crouch Branch Aquifer, and some a composite of the two. The lack of data exclusively for the McQueen Branch Aquifer makes determination of hydraulic characteristics difficult (Logan and Euler 1989). Because of the similarity in lithology, water levels, water quality, and the almost identical response of the water levels in both aquifers to applied stress in the up-dip areas (northeast of the Aiken-Barnwell County line at SRS), the two aquifers are considered part of the same hydrogeologic system, namely the Dublin-Midville Aquifer System.

\section{McQueen Branch Confining Unit}

The McQueen Branch Confining Unit separates the McQueen Branch Aquifer from the overlying Crouch Branch Aquifer. The unit is the up-dip equivalent of the Allendale Confining System (Figures 1-11 and 1-13).

The McQueen Branch Confining Unit is 16.8 (55 ft) thick in the P-27 well (Figure 1-9) and consists of the sandy clay confining beds in the middle one-third of the Black Creek Formation. The clay beds indicate deposition in lower delta plain environments, such as an interdistributary bay or backbarrier bay, where clay thicknesses can vary greatly over relatively short distances. The thickness of the unit is variable and ranges from 0 to $22.9 \mathrm{~m}(0$ to $75 \mathrm{ft})$ near the P-26 well in the southwest part of SRS. The unit thins and pinches out between wells P-27 and P-19 (Figure 1-9), leaving the McQueen Branch and Crouch Branch Aquifers in hydraulic communication. Farther south, between wells P-19 and P-24 (Figure 1-9), the confining unit is re-established and persists throughout the remainder of the SRS region.

The silty clays of the McQueen Branch Confining Unit become thicker and more continuous in the southern part of the study area. Here the unit is defined as the Allendale Confining System (Figures $1-11$ and 1-14). 


\section{Generalized Hydrogeologic Cross-Section for the Savannah River Site}

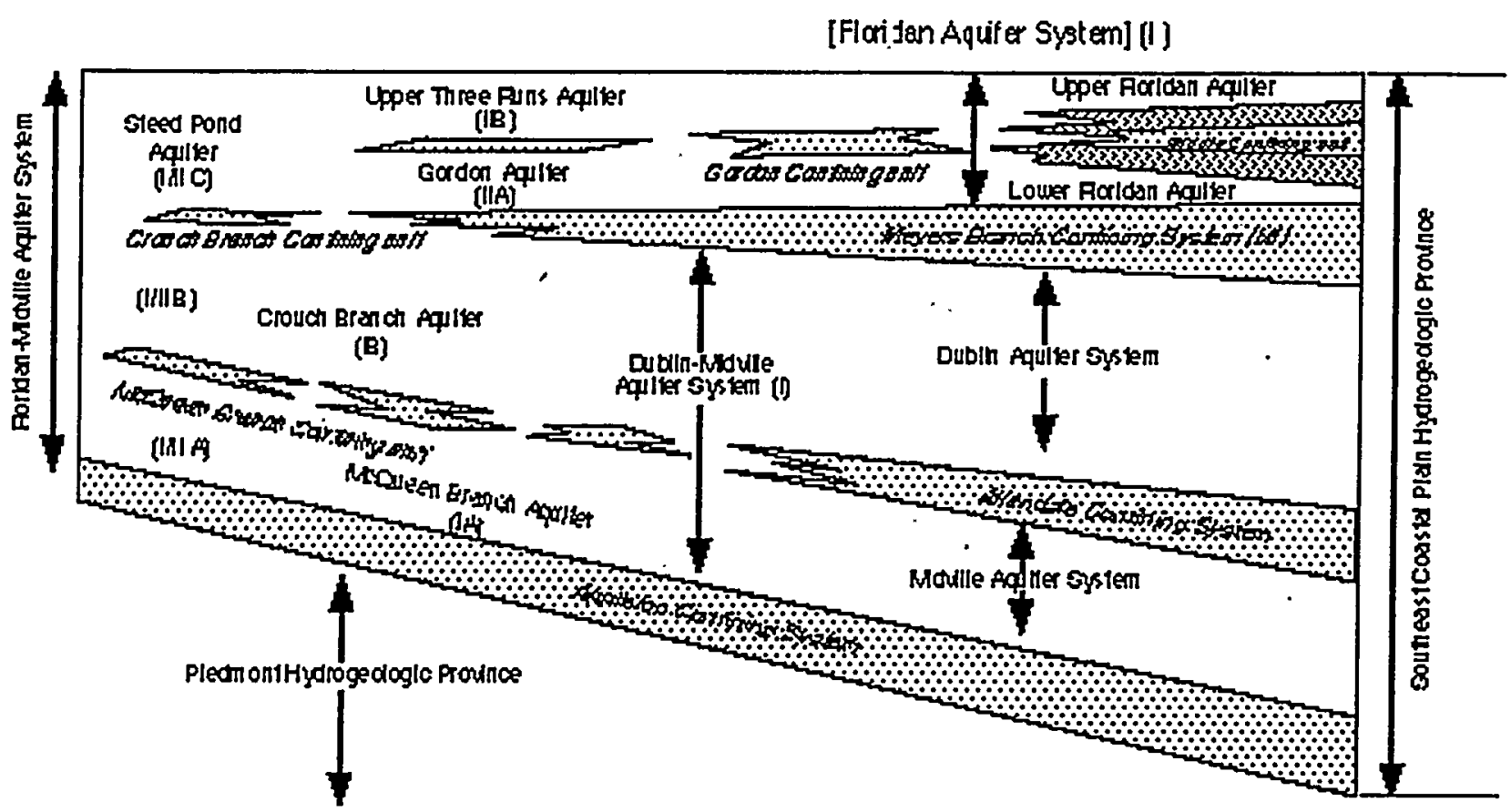

$94 \times 00187.32 \mathrm{LAL}$

Figure 1-16. Generalized hydrostratigraphic cross section of the SRS region (Aadland et al. 1992)

\section{Crouch Branch Aquifer Unit}

The Crouch Branch Aquifer is defined for sediments penetrated in well P-27 (Figure 1-9). The aquifer is overlain by the Meyers Branch Confining System in the central part of SRS, where the Dublin-Midville Aquifer System is defined, and by the Crouch Branch Confining Unit in the northwest part of SRS, where the aquifer is part of the Floridian-Midville Aquifer System (Figures 111 and 1-13). The Crouch Branch Aquifer is underlain by the McQueen Branch Confining Unit throughout the northern half of the study area.

The Crouch Branch Aquifer is located northwest of the line defining the up-dip limit of the Allendale Confining System (Figure 1-14). Southeast of the line and hydrostratigraphically equivalent to the Crouch Branch Aquifer is the Dublin Aquifer System. The aquifer persists throughout the northwestern half of SRS, but north of $A / M$ Area the Crouch Branch Confining Unit ceases to be effective, and the Crouch Branch Aquifer coalesces with the Steed Pond Aquifer to form the Hollow Creek Aquifer (Figure 1-17). 


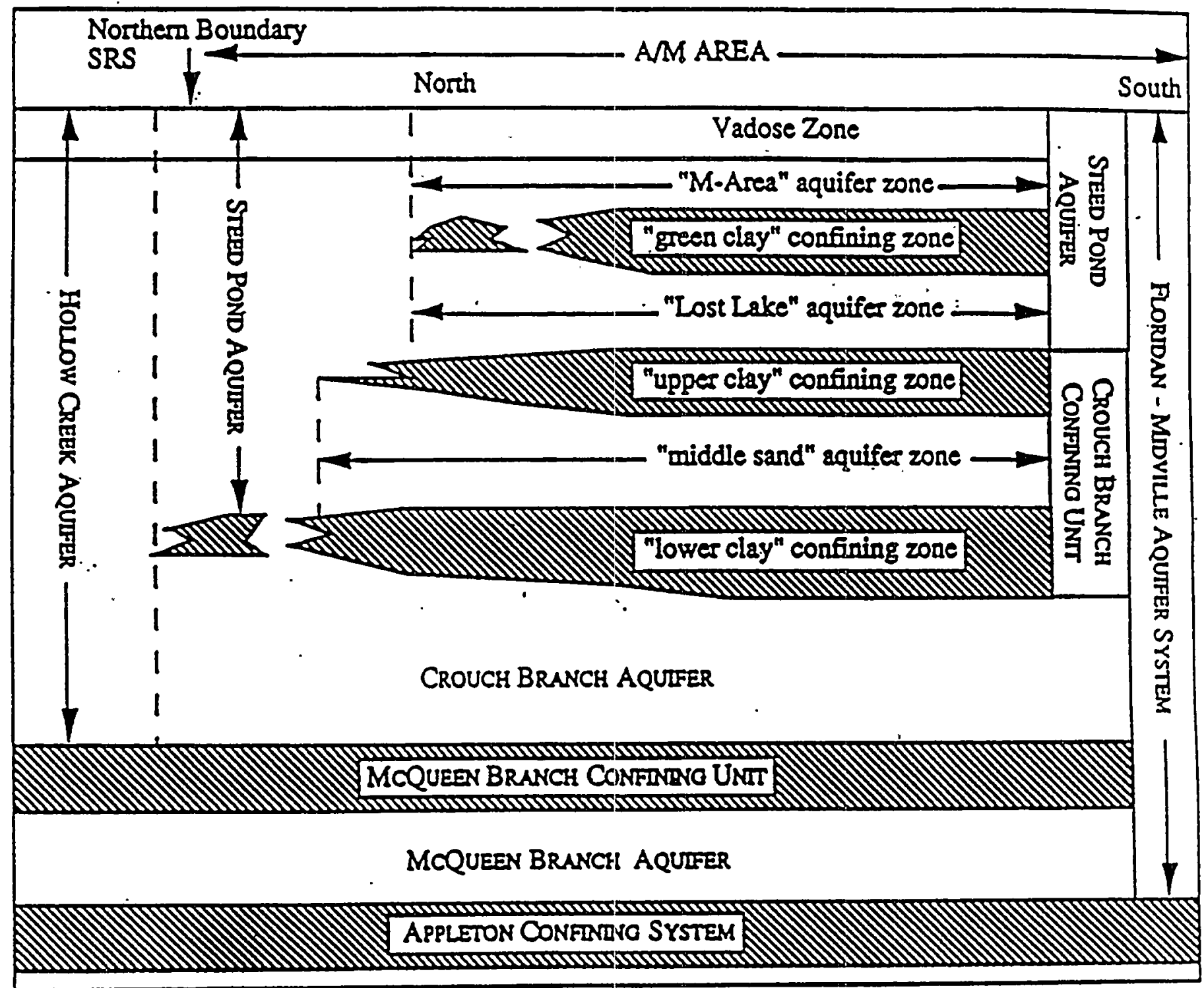

Figure 1-17. Hydrostratigraphic Chart for the A/M. Area (From WSRC-TR-92-355)

The Crouch Branch Aquifer is $75.3 \mathrm{~m}$ (247 ft) thick in well P-27 (Figure 1-9), and includes the sands in the upper one-third of the Black Creek Formation, which are better sorted, fine-grained and have a relatively high clay content relative to the overlying and underlying Cretaceous units, and the medium- to coàrse-grained, poorly to well-sorted sands and silty sands and thin beds of micaceous 
and carbonaceous clay in the overlying Peedee Formation. The Crouch Branch Aquifer varies in thickness from about 30 to more than $107 \mathrm{~m}$ (100 to more than $350 \mathrm{ft}$ ) (Figure 1-17). The thickness is very variable near the southeast boundary of the unit where sedimentation was affected, mostly during Paleocene time, by movement along the Pen Branch fault (Aadland and Bledsoe 1990a).

In the vicinity of $\mathrm{A} / \mathrm{M}$ Area, the Crouch Branch Aquifer consists mostly of tan to gray, white and yellow, very poorly to well-sorted, medium- to coarse-grained micaceous often pebbly sands. Here the aquifer ranges from 46.3 to $54.9 \mathrm{~m}$ (152 to $180 \mathrm{ft}$ ) in thickness. Sediments of the Crouch Branch Aquifer are chiefly sands, muddy sands, and slightly gravelly sands intercalated with thin, discontinuous layers of sandy clay and sandy mud.

\subsection{Floridan Aquifer System}

- Miller (1985) defines the Floridian Aquifer System as a "vertically continuous sequence of carbonate rocks of generally high permeability that are mostly of middle and late Tertiary age and. hydraulically connected in varying degrees and whose permeability is, in general, an order to several orders of magnitude greater than that of those rocks that bound the system above and below". Thus the definition of the Floridian Aquifer System is partly lithologic and partly hydraulic. The system is sometimes referred to as the principal artesian aquifer in South Carolina, Georgia, and Alabama (Stringfield 1966; Miller 1985).

The transition zone between the carbonate rocks of the Floridian Aquifer System and up-dip clastic facies equivalents of the system is the approximate northern extent of the thick carbonate platform that extended from the Florida peninsula through the coastal area of Georgia to southwestern South Carolina during early Tertiary time. The up-dip clastic facies equivalents of the Floridian carbonate rocks are not considered by Miller (1985) to be part of the Floridian Aquifer System. They are, however, hydraulically connected with it and are thus part of its regional flow system. Thus the updip clastic phase of the Floridian Aquifer System as defined in this report and the carbonate phase of the Floridian Aquifer System are treated as a single hydrologic unit because there are no regionally significant water-level differences between them and there is little evidence of an intervening confining unit (Aucott and Speiran 1985b).

The "clastic phase" of the Floridan Aquifer System is also referred to as the "Tertiary Sand" aquifer by Aucott and Speiran (1985a). Aucott and Speiran (1985a, b) combined all of the Eocene sandy units together (Barnwell Group, Santee Limestone, and Congaree Formation) into the "Tertiary Sand" aquifer because "they act hydraulically as a single aquifer in most of the State." In the study area, confining beds in these formations support a substantial head difference between overlying and underlying units. Here, the two aquifer units are defined and often can be further subdivided into aquifer and confining zones (Figures 1-11 and 1-17).

The sediments that define the Floridan Aquifer System are penetrated in the P-27 type well located near the center of SRS (Figure 1-9). Here the Floridan Aquifer System is divided into the Gordon Aquifer, the Gordon Confining Unit, and the Upper Three Runs Aquifer (Figure 1-11). The Upper Three Runs Aquifer can be subdivided into two aquifer zones over large parts of SRS, a lower aquifer zone and an upper aquifer zone separated by the "tan clay" confining zone. Both the Gordon Confining Unit and the "tan clay" confining zone are considered leaky (the "tan clay" confining zone more so than the Gordon Confining Unit), and the pressure relationships in general are downward from the upper aquifer zone to the lower aquifer zone down into the Gordon Aquifer.

North of the A/M Area at SRS (Figure 1-17), the Gordon Confining Unit pinches out and the Gordon and Upper Three Runs Aquifers coalesce to form the Steed Pond Aquifer. In addition, the Meyers Branch Confining System thins, becomes intermittent north of the $\mathrm{A} / \mathrm{M}$ Area, and the entire 
Floridian Aquifer System coalesces with the Dublin-Midville Aquifer System to form the FloridianMidville Aquifer System. Ultimately, the Steed Pond and Crouch Branch Aquifers coalesce to form the Hollow Creek Aquifer north of SRS in central Aiken County (Figure 1-17).

The Floridan Aquifer System consists of a thick sequence of Paleocene to late Eocene sands with minor amounts of gravel and clay and a few limestone beds. These were deposited under mostly marine conditions. In the southern part of the study area, the clastic sediments of the aquifer system underlie and grade directly into the platform limestones that form the "carbonate phase" of the Floridan. The boundary between the "clastic phase" and the "carbonate phase" of the aquifer system is not a well-defined confining unit but rather a lithologic transition. These two systems are directly connected hydraulically.

The Floridan Aquifer System overlies the Meyers Branch Confining System throughout the lower two-thirds of SRS. It includes all the Tertiary sediments from the water table to the confining beds in the Paleocene-aged Black Mingo Group (Figure 1-1.3).

The stratigraphic units that constitute the Floridan. Aquifer System in the study area include the Fishburne Formation and the locally sandy parts of the Williamsburg Formation of the Black Mingo Group, all of the Orangeburg and Barnwell Groups, and the overlying Miocene "upland unit" (Figure 1-13). Sediments from these Eocene and upper Faleocene units have been considered together because they act as a single hydrogeologic unit on a regional scale, as denoted by the general lack of a significant vertical hydraulic gradient between them (Aucott and Speiran 1985b).

\section{Gordon Aquifer Unit}

The Gordon Aquifer consists of all the saturated strata which lie between the Gordon Confining Unit and the Meyers Branch Confining System (Figures 1-11 and 1-13). The aquifer is semi-confined, with a downward potential from the "lower aquifer" zone of the overlying Upper Three Runs Aquifer providing recharge and indicating interconnection.

The Gordon Aquifer is defined by sediments penetrated in well P-27 (Figure 1-9). The unit is $23.5 \mathrm{~m}$ $(77 \mathrm{ft})$ thick in P-27 and consists of the sandy parts of the Williamsburg Formation and the overlying Fishburne and Congaree Formations. The unit is composed of yellow, orange, tan, well-sorted, fine to coarse-grained sands with common pebbly zones. Overall, the sediments suggest deposition in shoreline to shallow shelf environments. The Gordon Aquifer is dominantly a sub-angular, mediumto lower coarse-grained, slightly gravelly, sub-mature quartz sand.

The thickness of the Gordon Aquifer varies from about $45 \mathrm{ft}$ to more than $80 \mathrm{ft}$, generally thickening to the east and southeast (Figure 1-18). The Gordon Aquifer is partially eroded in the vicinity of the Savannah River and Upper Three Runs Creek.

The Gordon Aquifer provides water to SRS and to the surrounding rural population. The aquifer is capable of large yields at SRS (tens to hundreds of gallons per minute) and in nearby municipal wells. Siple (1967) reported maximum yields of $660 \mathrm{gpm}$ from some SRS wells that probably were pumping the Gordon Aquifer. Some municipal Congaree wells at Barnwell, South Carolina, yield $400 \mathrm{gpm}$. The number of users will probably increase as the region develops, but most users who require thousands of gallons per minute will develop wells within the Dublin-Midville Aquifer System. Thus, the total quantity pumped from the Gordon Aquifer will probably increase more slowly than the total quantity pumped from the Dublin-Midville Aquifer System. 
The Warley Hill Formation constitutes the Gordon Confining Unit and consists of fine-grained, glauconitic, silty sands and green clays. The Gordon Confining Unit separates the Gordon Aquifer from the "lower aquifer" zone of the overlying Upper Three Runs Aquifer. The Gordon Confining Unit has been informally termed the "green clay" at SRS. In the study area, the Warley Hill sediments are generally less than $15.2 \mathrm{~m}$ (50 ft) thick, and suggest shallow to deeper clastic shelf environments of deposition. The Gordon Confining Unit is defined by sediments penetrated in well P-27 located near the center of SRS (Figure 1-9). The unit is $2.1 \mathrm{~m}$ (7ft) thick in the P-27 well, and consists of a single sandy clay bed. The up-dip limit of the confining unit is illustrated on Figures 111 and 1-18.

Lithology of the Gordon Confining Unit is characterized by variable facies ranging from clay-rich, calcareous sediment in the southern one-third of SRS, to silty, clayey sands in the middle one-third of SRS, to relatively clean quartz sands to the north. As such, porosity and permeability of the confining unit vary widely and the confining characteristics decrease to only localized influence in the northern part of SRS north of the A/M Area (Figure 1-17). In the northwest part of SRS, the intermittent confining clays of the Warley Hill Formation constitutes the "green clay" confining zone of the Steed Pond Aquifer of the Floridan-Midville Aquifer System.

From Upper Three, Runs Creek to the vicinity of the P-21 and P-22 wells (Figure 1-9), the confining unit generally consists of one or more of the thin but persistent clay beds of the Warley Hill Formation, and constitutes the persistent clastic part of the Gordon Confining Unit. Southward from the P-21 and P-22 wells (Figure 1-9), however, the stratigraphic interval that includes the Gordon Confining Unit undergoes a facies change to the clayey micritic limestones and limy clays typical of the Blue Bluff Member of the overlying Santee Limestone, and constitutes the middle confining unit of the "carbonate phase" of the Floridan Aquifer System.

The Warley Hill Formation ("green clay") impedes the movement of water from the Santee Limestone to the Congaree Formation. This clay is a very effective confining unit between the Gordon Aquifer and the overlying Upper Three Runs Aquifer. In some areas, especially in the central and southern part of SRS, the Gordon Confining Unit supports a head differential of more than $24.4 \mathrm{~m}(80 \mathrm{ft})$.

The Gordon Confining Unit is reasonably competent, but still exhibits leakage. Laboratory analyses of physical characteristics, including horizontal and vertical permeability, were performed on representative undisturbed samples of the clayey parts of unit. Nine analyses were performed from wells completed in the General Separations Area. The range in values is from $1.16 \times 10^{-8}$ to $8.23 \times 10^{-4}$ $\mathrm{m} /$ day ( $3.8 \times 10^{-8}$ to $2.7 \times 10^{-3} \mathrm{ft} /$ day). The dry unit weights range from 815 to $1703 \mathrm{~kg} / \mathrm{m}^{3}$ (50.9 to 106.3 lbs./ft ${ }^{3}$ ). In general, the higher unit weights indicate that the Gordon Confining Unit is a dense and compact clay. The lower values result from lighter organic material in some samples of the clay. 


\section{GROUNDWATER PROTECTION

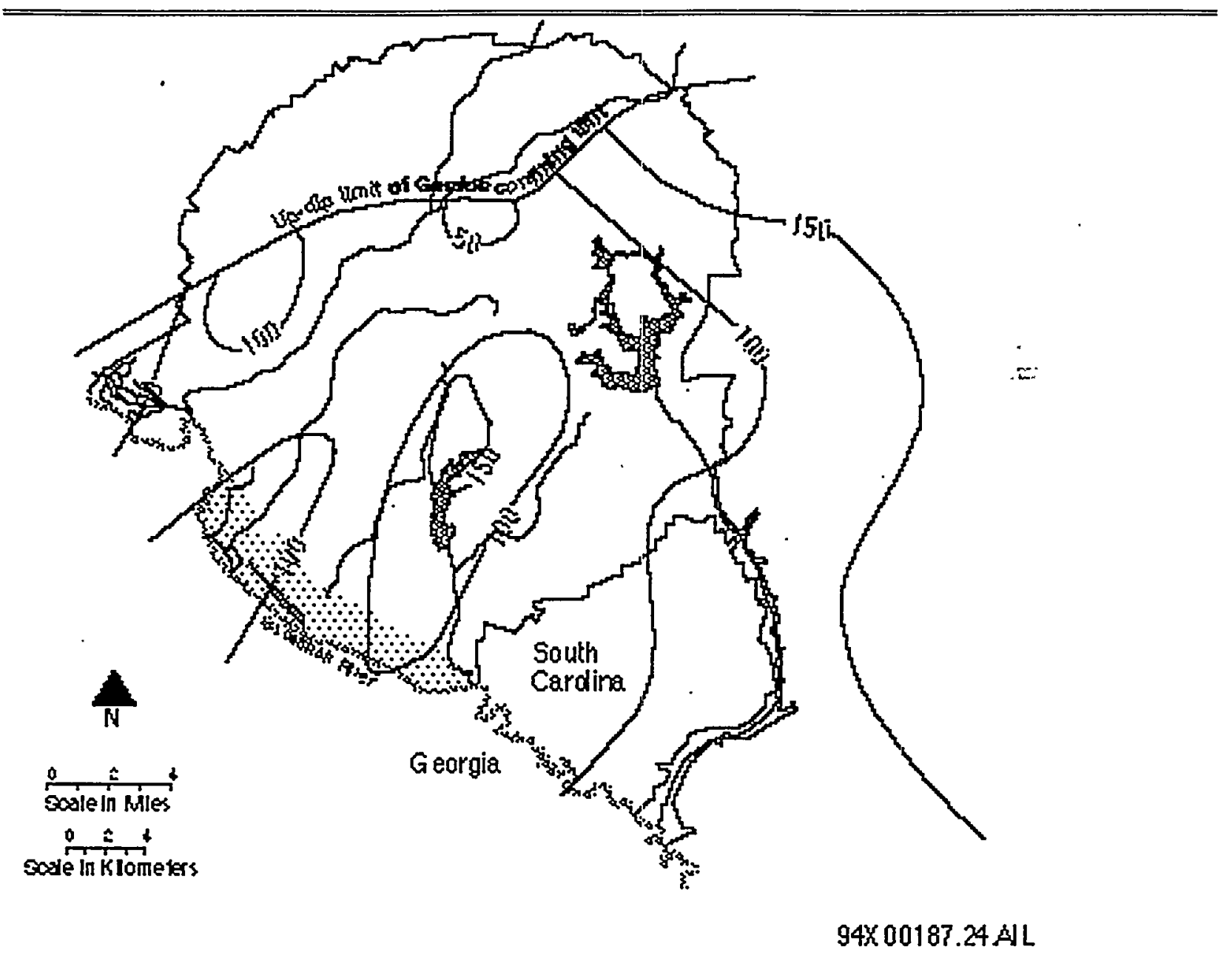

Figure 1-18. Isopach map of the Gordon Aquifer Unit Aadland et al (1992) 


\section{Upper Three Runs Aquifer}

The Upper Three Runs Aquifer corresponds to all the geologic formations above the Warley Hill Formation, and includes the sandy and sometimes calcareous sediments of the Santee Limestone and all the heterogeneous sediments in the overlying Barnwell Group from the water table down to the Gordon Confining Unit. The Upper Three Runs Aquifer is the up-dip clastic facies equivalent of the upper Floridan Aquifer of the "carbonate phase" of the Floridan Aquifer System (Figure 1-11).

Porosity and permeability of the aquifer are generally high, although interbedded clay layers function as local aquitards. In the vicinity of the $\mathrm{F}$ and $\mathrm{H}$ Areas, clay layers within the Dry Branch Formation ("tan clay" confining zone) are effective enough to merit subdividing the aquifer into an "upper aquifer" zone and a "lower aquifer" zone separated by the "tan clay" confining zone. The Upper Three Runs Aquifer is not currently used as a source for process water within SRS. Privately owned, shallow wells outside of SRS, which penetrate the aquifer, are employed for domestic water consumption.

The Upper Three Runs Aquifer is defined for sediments penetrated in well P-27 located near the

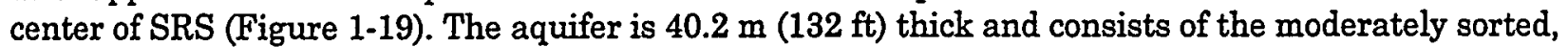
yellow and tan sand, calcareous sands and clays, limestones, and clay of the Santee Limestone, and variably colored, poorly to well-sorted sand with interbedded tan to gray clays, calcareous sands and clays of the Dry Branch Formation; and the moderately to poorly sorted, variably-colored fine to coarse sands and pebbly sands and minor clay beds of the Tobacco Road Sand. The unit varies from less than 3.0 to over $61 \mathrm{~m}$ (less than 10 to over $200 \mathrm{ft}$ ) in thickness across the study area.

In the General Separations Area, clay layers within the Dry Branch Formation ("tan clay" confining zone) are effective enough to merit subdividing the aquifer into an "upper aquifer" zone and a "lower aquifer" zone separated by the "tan clay" confining zone. The Upper Three Runs Aquifer is not currently used as a source for process water within SRS. Privately owned, shallow wells outside of SRS, which penetrate the aquifer, are employed for domestic water consumption.

Generally, the water table of the Upper Three Runs Aquifer is found within the Barnwell Group sediments. Where this is true, the "tan clay" confining zone located near the base of the Barnwell Group impedes the vertical movement of water and supports a head difference in some areas between the Barnwell and underlying Santee Limestone of about $3.6 \mathrm{~m}(12 \mathrm{ft})$. Thus, in many areas at SRS, especially in the General Separations Area near the center of the site, the "tan clay" confining zone divides the Upper Three Runs Aquifer into two aquifer zones.

No composite data are available for the entire Upper Three Runs (water-table) Aquifer. Thus, the discussion of hydraulic property estimates for the aquifer is subdivided into the "lower aquifer" zone of the aquifer (consisting of the Santee Limestone) and the "upper aquifer" zone (consisting of the Barnwell Group). As noted in the discussion of the Gordon Aquifer, large discharge aquifer tests conducted in the "lower aquifer" zone of the Upper Three Runs Aquifer were probably performed in wells primarily screened in the Gordon. Therefore, there are few large-scale aquifer test results solely from the "lower aquifer" zone.

The "upper aquifer" zone consists of all the saturated strata which lie between the water table and the "tan clay" confining zone. This zone has a general downward potential into the underlying aquifer units. The "tan clay" confining zone impedes the movement of water through it; however, it does allow for some recharge to the "lower aquifer" zone. Above the clay is the "upper aquifer" zone, which consists of silty sand of the Dry Branch Formation that is slightly more permeable than an overlying clayey sand of the Tobacco Road Sand. 


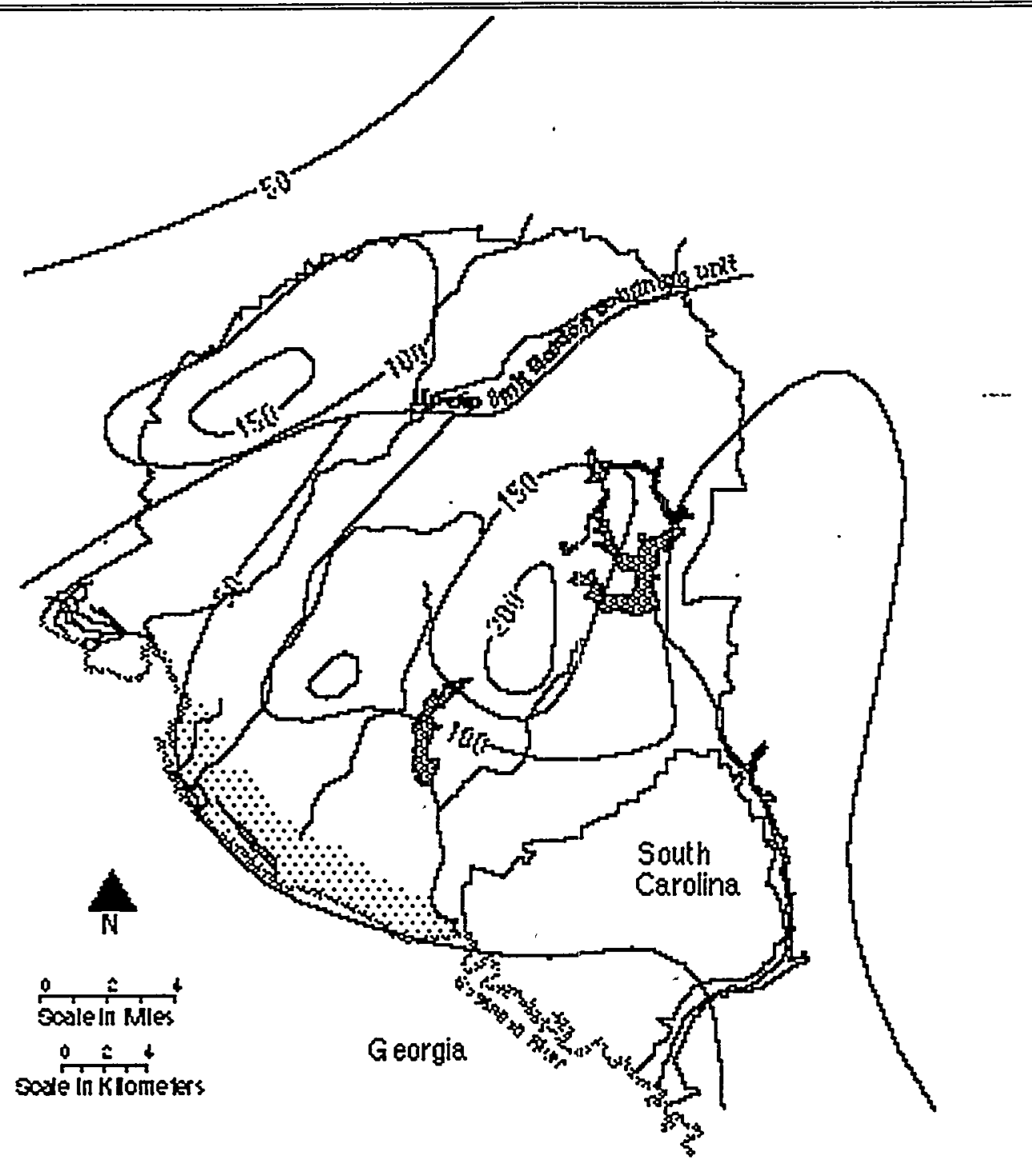

$94 \times 00187.25 \mathrm{AlL}$

Figure 1-19. Isopach map of the Upper Three Runs and Steed Pond Aquifer Units (Aadland et al. 1992)

The "lower aquifer" zone of the Upper Three Runs Aquifer consists of saturated strata which lie between the "tan clay" confining zone and the Gordon Confining Unit. This zone is poorly confined and is recharged primarily by downward flow from the upper aquifer zone.

The vertical component of flow in the lower aquifer zone is downward across the Gordon Confining Unit into the Gordon Aquifer. The Gordon Confining Unit is more competent than the "tan clay" confining zone, but there is evidence of leakage where the clay beds thin and are discontinuous, and where the clays have been breached by slumping observed in the General Separations Area.

\subsection{Floridan-Midville Aquifer System}


Northwest of Upper Three Runs Creek, the permeable beds that correspond to the Floridan and the Dublin-Midville Aquifer Systems are often in overall hydrologic communication due to the thin and sporadic character of the intervening clay and silty clay beds that are correlative with the Meyers Branch Confining System, and to erosion by the local stream systems that dissect the interval. Here the Floridan and Dublin-Midville Aquifer Systems coalesce to form the Floridan-Midville Aquifer System (Figures 1-15 and 1-17). The Floridan-Midville is defined for sediments located in the $A / M$

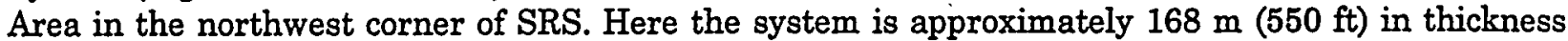
and includes the entire stratigraphic section, from the water table to the Appleton Confining System (Figure 1-13).

The Floridan-Midville Aquifer System is divided into three aquifers: from base upwards the McQueen Branch, the Crouch Branch, and the Steed Pond Aquifers, separated by the McQueen Branch and Crouch Branch Confining Units (Figure 1-17). Both the McQueen Branch and the Crouch Branch Aquifers extend northwestward from the central part of SRS where they are defined and are an integral part of the Dublin-Midville Aquifer System.

North of Upper Three Runs Creek the permeable beds that correspond to the Gordon and Upper Three Runs Aquifers of the Floridan Aquifer are in overall hydraulic communication due to the thin and intermittent character of the intervening clay beds (Warley Hill Formation) of the Gordon Confining Unit, and to erosion by the local stream systems that dissect the interval..Here the aquifers coalesce to form the Steed Pond Aquifer of the Floridan-Midville Aquifer System (Figures 111 and 1-16). The up-dip limits of the Gordon Confining Unit and the Meyers Branch Confining System are not parallel to each other (Figure 1-14). The Steed Pond Aquifer projects south beyond the up-dip limit of the Meyers Branch Confining System in the northwest corner of SRS (Figure 119). The Gordon and the Upper Three Runs Aquifers project north past the up-dip limit of the Meyers Branch Confining System in the northeast corner of SRS (Figures 1-18 and 1-19).

\section{Steed Pond Aquifer}

The Steed Pond Aquifer is well developed in the A/M Area in the northwestern corner of SRS. The aquifer includes all the sediments from the water table down to the clays and clayey sands of the Crouch Branch Confining Unit (Figure 1-17). Locally, as in the vicinity of A/M Area, the Steed Pond Aquifer can be divided into three zones, the lower "Lost Lake" Aquifer Zone and the "M Area" Aquifer Zone, separated by the clay and clayey sand beds of the "green clay" confining zone (Figure 1-17) (Aadland et al. 1992).

In A/M Area, the "Lost Lake" Aquifer Zone of the Steed Pond Aquifer consists of the undifferentiated sands of the Congaree and Fishburne Formations. The zone is approximately 16.8 to $24.4 \mathrm{~m}$ (55 to 80 $\mathrm{ft}$ ) in thickness and consists of yellow, tan, orange and brown, loose to slightly indurated, fine to coarse, moderately to well-sorted, occasionally pebbly sand (Aadland et al., 1992).

The "green clay" confining zone is correlative with the clay and silty clay beds of the Gordon Confining Unit that separate the Gordon and Upper Three Runs Aquifers of the Floridan Aquifer System south of Upper Three Runs Creek (Figure 1-15). The "green clay" confining zone consists of the mostly orange and yellow, fine to coarse, poorly to well-sorted often pebbly sands interbedded with zero to three, clay to silty clay beds of the Warley Hill Formation (Aadland et al. 1992).

North of the SRS boundary, the "green clay" confining zone is no longer effective in separating the "Lost Lake" Aquifer Zone from the overlying "M-Area" Aquifer Zone. Here only the undifferentiated Steed Pond Aquifer is present. Hydraulic conductivity values for the "green clay" confining zone in the A/M Area are in the range of $10^{-8}$ to $10^{-5} \mathrm{~cm} / \mathrm{sec}$ (Eddy et al. 1991). Values for total porosity are in the expected range for clay samples with most values ranging between 0.35 and 0.6 . Leakance 
values ranged from $4.58 \times 10^{-2}$ to 3.25 for several aquifer tests using the M-Area recovery wells (Hiergesell 1993; 1994; Hiergesell et al. 1994). These values indicate that vertical flow into the "Lost Lake" Aquifer Zone is restricted by the "green clay" confining zone.

The "M-Area" Aquifer Zone of the Steed Pond Aquifer extends from the water table to the "green clay" confining zone (Figure 1-22). The zone averages about $9.1 \mathrm{~m}(30 \mathrm{ft})$ in thickness, and consists of sands of the Santee Formation that are below the water table. The aquifer zone is composed of orange to tan and yellow, fine to coarse, poorly to well-sorted sand. The water table surface ranges from $70.7 \mathrm{~m}(232 \mathrm{ft}) \mathrm{msl}$ in the northern A/M Area to $61.9 \mathrm{~m}(203 \mathrm{ft}) \mathrm{msl}$ in the southern A/M Area near Tims Branch.

The Steed Pond Aquifer consists of unconsolidated quartz sand that contains thin; discontinuous layers of sandy silt, sandy mud, and sandy clay.

\section{Crouch Branch Confining Unit}

The Crouch Branch Confining Unit separates the Steed Pond Aquifer from the underlying Crouch Branch Aquifer (Figures 1-11 and 1-17). The unit varies in thickness from zero to the north of $A / M$ Area to more than $100 \mathrm{ft}$ to the south. The Crouch Branch Confining Unit is divided into the following three hydrogeologic zones: the "lower clay" confining zone, the "middle sand" aquifer zone, and the "upper clay" confining zone (Figure 1-17).

Sands of the "middle sand" aquifer zone have often been referred to as the lower Congaree sands and/or the Ellenton sands (Geraghty and Miller 1986). They were thought to be in hydraulic communication with the overlying Congaree-Fishburne Formation sands. In places, the clay bed that caps the unit ("upper clay" confining zone) is very thin or absent. Here, only the basal clay ("lower clay" confining zone of the Crouch Branch Confining Unit) that directly overlies the uppermost Peedee sand is capable of acting as the confining unit between the "Lost Lake" Aquifer Zone of the Steed Pond Aquifer and the underlying Crouch Branch Aquifer. The sands in the "middle sand" zone of the Crouch Branch Confining Unit are thus often connected hydraulically to the "Lost Lake" Aquifer Zone and are considered to be part of the overlying Steed Pond Aquifer (Figure 1-17).

To the north, the "lower clay" confining zone of the Crouch Branch Confining Unit is missing, and the Crouch Branch Confining Unit is breached. Here the Crouch Branch Aquifer is in direct hydraulic communication with the overlying Steed Pond Aquifer. North of the site boundary, the Crouch Branch Confining Unit ceases to be an effective barrier to water flow and the Steed Pond Aquifer coalesces with the underlying Crouch Branch Aquifer forming the Hollow Creek Aquifer (Figure 1-17).

The "lower clay" confining zone has been referred to as the lower Ellenton clay, the Ellenton clay, the Peedee clay, and the Ellenton/Peedee clay in previous SRS reports. The "lower clay" confining zone consists of the variegated gray, red, purple, yellow, and orange and in places dark to light gray massive clay bed that caps the Peedee Formation. The "lower clay" confining zone is variable in

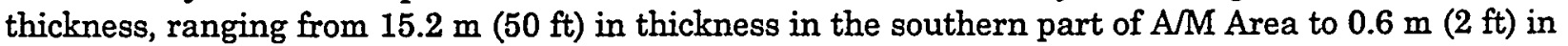
the north.

The "middle sand" aquifer zone consists of the very poorly sorted sediments of the Ellenton Formation. The "middle sand" aquifer zone consists of either dark gray to black, poorly sorted, fine to coarse, clayey, silty occasionally pebbly quartz sand and dark, kaolinitic clay and clayey silt., The aquifer zone is very variable in thickness, ranging from 13.7 to $2.4 \mathrm{~m}$ ( 45 to $8 \mathrm{ft}$ ). 
The "upper clay" confining zone often consists of the gray, tan, yellow, green, orange, brown, and purple silty clays. In the northern part of $A / M$ Area, the confining zone consists of dark gray to black, fissile, well indurated silty clays very similar to the silty clays in the underlying Ellenton section. The thickness of "upper clay" confining zone varies from 0 to $4.6 \mathrm{~m}$ ( 0 to $15 \mathrm{ft}$ ) in A/M Area.

\section{Hollow Creek Aquifer Unit}

At the northwestern edge of SRS, immediately north of A/M Area, the clay and silty clay beds of the Crouch Branch Confining Unit pinch out (Aadland et al. 1992), and the Crouch Branch Aquifer and the Steed Pond Aquifer coalesce forming the Hollow Creek Aquifer

The aquifer includes all the sediments from the water table to the McQueen Branch Confining Unit. Further north beyond the C-2 well (Figure 1-9), all the aquifers of the Coastal Plain sequence are in communication due to the up-dip stratigraphic position of the sequence and to erosion and surface exposure of the sequence. This is the catchment area for the entire Coastal Plain sequence and it acts as a single aquifer from the water table to the basement.

The Hollow Creek Aquifer is defined for sediments penetrated in well C-2 located four miles northwest of SRS near Hollow Creek. The aquifer consists of sediments of the upper part of the Black Creek Formation and the Peedee Formation of the Lumbee Group, and any Tertiary sediments found below the water table. The Hollow Creek Aquifer is separated from the underlying McQueen Branch Aquifer by the clays of the McQueen Branch Confining Unit that continue to persist in the far up-dip section.

\section{Vadose Zone}

The vadose zone extends from the ground surface to the water table. The vadose zone is a heterogeneous unit of clean, clayey, or silty sand through which the uppermost aquifer is recharged. No areally extensive, low-permeability layers have been identified in the zone. Undisturbed samples from discontinuous low permeability layers have been collected at several General Separations Area borings.

\subsubsection{Confining Systems of the Southeastern Coastal Plain}

\subsection{Introduction}

In ascending order the confining systems are the Appleton Confining System, the Allendale Confining System, and the Meyers Branch Confining System. The approximate up-dip limit of each confining system is summarized on Figure 1-14. Detailed technical information on each of these units is available in (Aadland and Bledsoe 1990a).

\subsection{Appleton Confining System}

The Appleton Confining System rests directly on crystalline basement rocks and the sedimentary rocks of the Newark Supergroup which constitute the Piedmont hydrogeologic province (Figures 1-11 and 1-13). The Appleton Confining System is essentially equivalent to the saprolite overlying the un.weathered crystalline basement rocks and the indurated, poorly sorted, silty clayey sands and sand beds of the Cretaceous-aged Cape Fear Formation

The Appleton Confining System is defined by sediments penetrated at the C-10 type well located near the town of Allendale,. in Allendale County, South Carolina. Here the unit is $73 \mathrm{~m}$ (240 ft) thick and consists of saprolite derived from basement rocks, and the interbedded sands, clayey sands, and 
clays of the Cape Fear Formation. The Cape Fear Formation consists of stiff gray, brown, or variegated red, tan, and gray, silty clays and stiff gray, red, or brown, micaceous, very clayey, very silty, feldspathic, very fine to very coarse sands. Sorne coarse pebble zones are present. Up-dip, the Appleton Confining System is typified by sediments penetrated in SRS well PBF-3 (Figure 1-9).

The Appleton Confining System is typical of the seaward-thickening sedimentary wedge that constitutes the Southeastern Coastal Plain hydrogeologic province. It dips at about $5.9 \mathrm{~m} / \mathrm{km}$ (31 $\mathrm{ft} / \mathrm{mi}$ ) to the southeast, and thickens from $6.1 \mathrm{~m}(20 \mathrm{ft})$ in the northern end of SRS to $72.2 \mathrm{~m}(237 \mathrm{ft}$ ) near the town of Allendale (Figure 1-20). The Appleton Confining System includes no aquifer units or zones within the study area.

\subsection{Allendale Confining System}

The Allendale Confining System is present in the southeastern half of the study area, and separates the Midville Aquifer System from the overlying Dublin Aquifer System (Figures 1-11 and 1-13). The up-dip limit of the system is illustrated on Figure 1-14. North of the up-dip limit, the thinner, intermittent clay beds of the McQueen Branch Confining Unit separate the McQueen Branch and Crouch Branch Aquifer Units of the Dublin-Midville Aquifer System (Figure 1-11). The confining system thickens uniformly from about $15 \mathrm{~m}(50 \mathrm{ft})$ at the up-dip limit to more than $61 \mathrm{~m}(200 \mathrm{ft})$ near the southeastern boundary of the study area.

The Allendale Confining System is defined for sediments penetrated in the C-10 type well located near the town of Allendale, Allendale County, South Carolina. Here the system is $53.3 \mathrm{~m}$ (175 ft) thick and consists primarily of clay and sandy clay with minor interbedded sand and clayey sand. The total clay thickness is $48.2 \mathrm{~m}$ (158 ft) ( $90 \%$ clay and sandy clay). Overall, the system consists of beds of slightly lignitic, glauconite-bearing, very micaceous clay, with occasional silty, sandy clay beds present. Up-dip, the Allendale Confining System is $28.3 \mathrm{~m}(93 \mathrm{ft})$ thick with a total clay thickness of $18.0 \mathrm{~m}$ (59 ft) (63\% clay and sandy clay) at SRS well P-22 located near the system's updip limit (Figure 1-9).

\subsection{Meyers Branch Confining System}

The Meyers Branch Confining System separates the Floridan Aquifer System from the underlying Dublin and Dublin-Midville Aquifer Systems (Figures 1-11 and 1-13). This regional confining system is locally absent in up-dip parts of the Coastal Plain in eastern Georgia and western South Carolina where the Floridan and Dublin-Midville Aquifer Systems are in direct communication and the aquifer systems coalesce to form the Floridan-Midville Aquifer System (Figure 1-14).

The Meyers Branch Confining System consists of the clays, silts, and poorly sorted, muddy sands of the Ellenton Formation; the sands and interbedded silty clays and clays of the Williamsburg Formation; and the lignitic clays and interbedded sands at the top of the Peedee Formation. In the northwestern part of the study area, the sediments in the stratigraphic interval that includes the Meyers Branch Confining System are increasingly better sorted and less silty, with thinner clay interbeds than the interval to the south. It is here that the Meyers Branch Confining System ceases to act as a confining system and the system is down-graded to the Crouch Branch Confining Unit of the Floridan-Midville Aquifer System (Figures 1-11 and 1-17). In this part of SRS, the Crouch Branch Confining Unit corresponds only to the silty clays and clayey sands within the upper part of the Peedee Formation and the overlying Ellenton Formation (Aadland et al. 1992). 


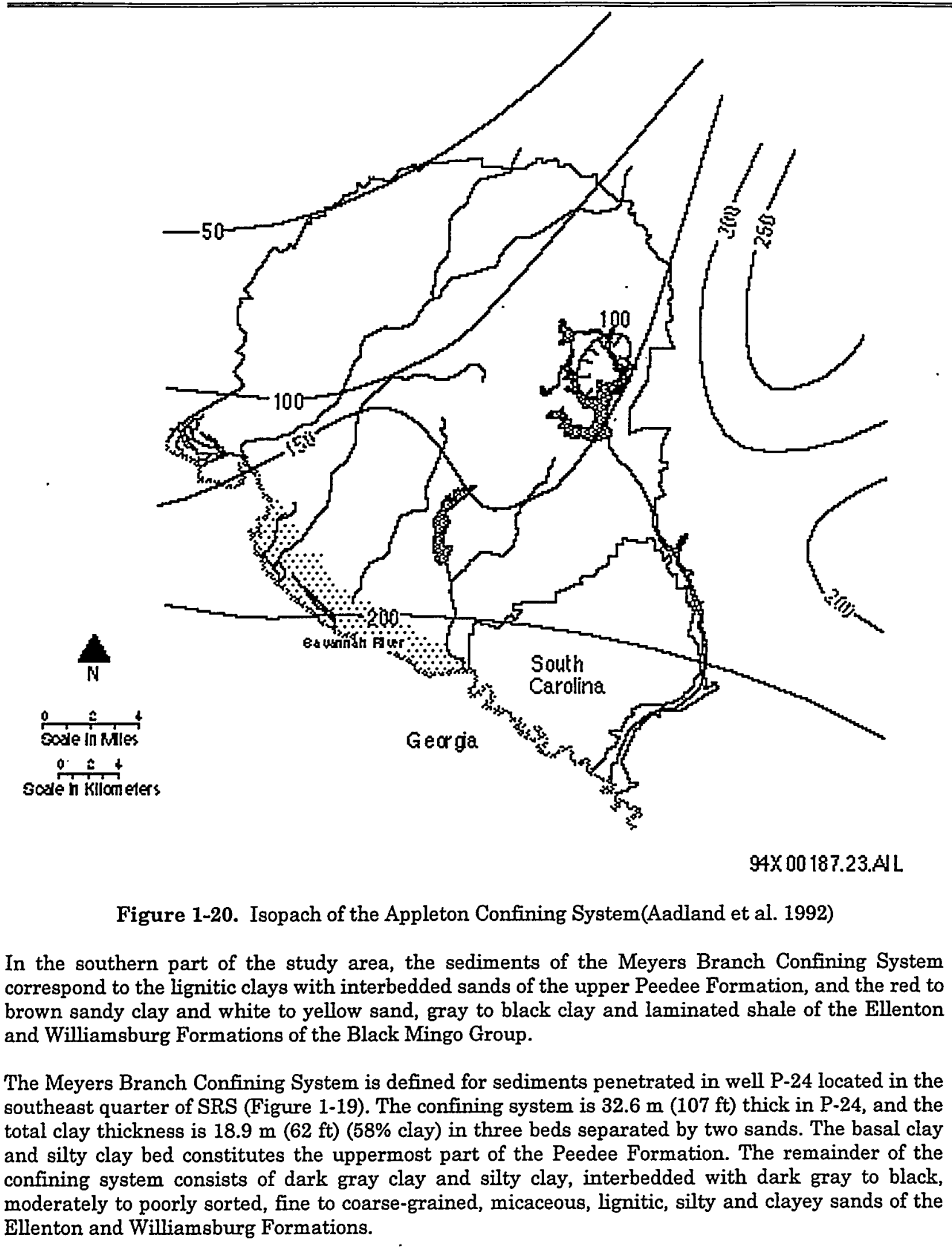


Sediments of the Meyers Branch Confining System are mainly poorly sorted, gravelly sandy mud, sandy mud, and sandy clay according to the classification of Folk (1954). The thickness of the Meyers Branch Confining System varies from about 9 to $61 \mathrm{~m}$ (30 to $200 \mathrm{ft}$ ). The Meyers Branch Confining System was penetrated in 15 borings in the General Separations Area and attains a thickness of more than $30 \mathrm{~m}(100 \mathrm{ft})$ in this part of SRS.

\subsection{SUBSURFACE HYDROGEOLGY AND GEOCHEMISTRY}

\subsubsection{Groundwater Flow}

Groundwater flow is determined by the hydraulic properties and geometry of the subsurface system and by the proximity to groundwater discharge and recharge areas. Discharge areas can be surface features such as streams and creeks that receive groundwater flow. A recharge area may be an area that receives rainfall, or it may result from groundwater flowing from one aquifer to another.

The direction of groundwater flow in unconsolidated sediments is always perpendicular to the equipotential (constant hydraulic head) contours. It is important to recognize that groundwater flow is three-dimensional, and as a result, one must consider the hydraulic head not only in the aquifer of interest, but also in the aquifers above and below to determine the direction of groundwater flow.

This chapter describes groundwater flow at SRS in sufficient detail to provide a foundation for understanding the subsurface system. This chapter will not provide all the information associated with specific areas of the site. For more detailed local-scale information, the reader is directed to siteor area-specific documents.

\subsubsection{Piedmont Hydrogeologic Province}

The basement complex, designated the Piedmont hydrogeologic province, consists of crystalline rocks or consolidated to semi-consolidated sedimentary rocks, all of which have low hydraulic conductivity (Wait and Davis 1986). Several years ago, the groundwater flow in this province was studied at SRS to assess the safety and feasibility of storing radioactive waste in these rocks (Marine 1967a, b; 1966, 1974; Webster et al. 1970).

Water injection and withdrawal tests were conducted on the metamorphic crystalline basement rocks that underlie SRS. The tests indicated that two types of fractures exist in the crystalline bedrock (Marine 1966). The first consists of minute fractures that pervade the entire rock mass but transmit water slowly. Rocks containing only this type of fracture are called "virtually impermeable rocks". The second type of fracture has larger openings that transmit water more readily, and are vertically restricted but can be traced laterally. Rocks containing this type of fracture are called "hydraulically transmissive rocks".

Hydraulic head measurements were made in the deep-rock borings that penetrated the basement rocks and in wells completed in the overlying sediments (Logan and Euler 1989). These measurements indicate a head difference averaging about $4.3 \mathrm{~m}$ (14 ft) between the crystalline rock of the Piedmont hydrogeologic province and the overlying sediments of the Southeastern Coastal Plain hydrogeologic province, with the crystalline rock having the greater head. This head difference is largely caused by the continuous pumping of process-water supply wells in the area, which reduce the head in the Midville and Dublin-Midville Aquifer Systems. When compared with static water levels before plant operations began, the head in the crystalline rock is about $0.6 \mathrm{~m}(2 \mathrm{ft})$ higher than the head in the overlying aquifer systems. There appears to be a regional upward gradient through 
the Appleton confining system between the Piedmont hydrogeologic province and the overlying Southeastern Coastal Plain hydrogeologic province. The Appleton confining system forms an effective seal that separates the two hydrogeologic provinces allowing the difference in head between the provinces to persist.

Marine (1979) presented a potentiometric map for groundwater in the crystalline metamorphic rock of the Piedmont hydrogeological province (Figure 1-21). Heads range from more than $70 \mathrm{~m}(230 \mathrm{ft})$ msl along the Fall Line in northern Aiken County to $59 \mathrm{~m}(195 \mathrm{ft}) \mathrm{msl}$ near the center of SRS, to 33.5 $\mathrm{m}$ (110 ft) $\mathrm{msl}$ along the Savannah River where the river crosses the Fall Line. These potentials define an arcuate path, first flowing south from the recharge area along the Fall Line, then swinging to the west beneath SRS, and then moving north to the discharge area near the intersection of the Savannah River with the Fall Line. This flow has been estimated at about $6.3 \mathrm{~cm} / \mathrm{yr}(2.5$ in./yr) (Marine 1979). Because the data are sparse, Logan and Euler (1989) suggest that it is unclear whether this indicates a regional direction of flow or simply an alteration of the flow path because of the local orientation of the fracture zones.

Water in the Paleozoic bedrock is not pumped at SRS except for testing programs. The Paleozoic bedrock will not be used as a water source at SRS or in surrounding communities because of its very low capacity to transmit water to a well. Therefore, the hydrologic regime of the metamorphic and igneous basement rocks at SRS is unlikely to change appreciably for many decades. Immediately south of the Fall Line and to the north of it in the Piedmont, the Paleozoic metamorphic and igneous rocks are domestic aquifers.

\section{Triassic Dunbarton Basin}

Ground water in the Dunbarton Basin contains high levels of dissolved solids, approaching the levels of sea water (Marine 1974). It is also characterized by hydraulic head values which are significantly higher than in the overlying Coastal Plain aquifers. Two of the wells have heads which are over 200 feet higher than in the overlying Midville Aquifer (Marine 1974).

Marine (1974) evaluated several possible explanations for these high head conditions. Three potential explanations remain plausible after that analysis: osmotic-membrane phenomena, current tectonic compression, and warming due to post-Pliestocene climatic changes. Of these explanations, the osmotic-membrane mechanism is the most plausible. 


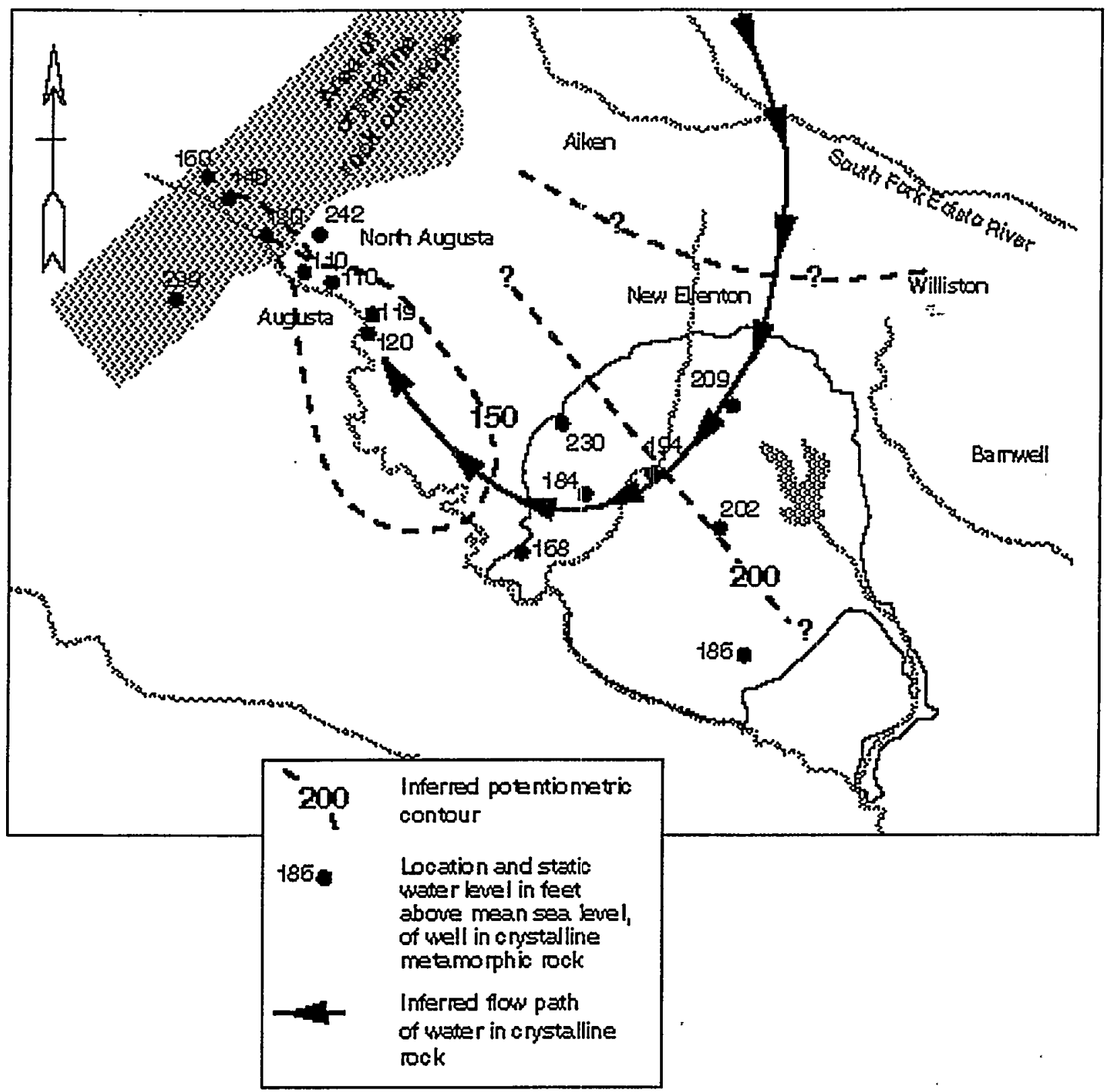

$9+\times 03675.13 \mathrm{RL}$

Figure 1-21. Potentiometric map for the Crystalline metamorphic bedrock (Source: Marine 1979)

\subsubsection{Groundwater Flow in the Atlantic Coastal Plain}

Introduction

Sediments of the Atlantic Coastal Plain were laid down during a series of transgressions and regressions of the sea. The character of the sediments indicates depositional environments ranging from fluvial, to deltaic, to shallow marine. This variety in depositional conditions results not only in wide variations in lithology, but in a complex system of transmissive and confining bodies of sediment, respectively termed aquifers and aquitards. 
The following discussion of groundwater flow begins with the deepest aquifers at SRS and proceeds to shallower units. Flow in the confining units is not addressed because few hydraulic head measurements are available for these units and, to a good approximation, flow in aquitards is predominantly limited to vertical flow between aquifer units.

Dublin/Midville Aquifer System

McQueen Branch Aquifer

This aquifer has also been called the Middendorf, the Lower Cretaceous, the Lower Tuscaloosa, and Aquifer IA in previous SRS reports. A potentiometric map for the McQueen Branch Aquifer beneath SRS is shown in Figure 1-22. In general, horizontal flow in this aquifer is towards the Savannah River. Based on the low conductivity of the sediments comprising the Appleton Confining System beneath this aquifer and the weak vertical gradients with the overlying Crouch Branch Aquifer, the flow in this aquifer is essentially horizontal over most of SRS. However, there is a strong upward hydraulic gradient near the Savannah River, which is presently believed to be the discharge point for this aquifer. Regional hydraulic heads in both Georgia and South Carolina also indicate that the Savannah River is the ultimate discharge for this aquifer in the vicinity of SRS (Aadland 1992). Recharge of this aquifer likely occurs near SRS where the sediments comprising this aquifer (predominantly the Middendorf Formation) are exposed near the Fall Line.

The McQueen Branch Aquifer is highly transmissive. It therefore serves, in part, as the major production aquifer for much of SRS. In the past, groundwater production wells at SRS were screened in both the McQueen Branch and Crouch Branch Aquifers. In 1985 the site committed to the SCDHEC to only complete production wells in the McQueen Branch Aquifer in order to minimize potential for contamination reaching production wells and spreading of contamination in the deeper aquifers.

Crouch Branch Aquifer

This aquifer has also been called the Black Creek, the Tuscaloosa, the Upper Cretaceous, or Aquifer IB in previous SRS reports.

A potentiometric map for the Crouch Branch Aquifer beneath SRS is shown in Figure 1-23. Flow in the Crouch Branch Aquifer is more complicated than flow in the deeper McQueen Branch Aquifer because of the apparent communication with the Upper Three Runs tributary to the Savannah River. Horizontal flow in the Crouch Branch Aquifer is predominantly toward the Savannah River. However, there is a significant vertical flow component near the Savannah River and Upper Three Runs.

The vertical component of flow in the Crouch Branch Aquifer is demonstrated in (Figure 1-24), where the hydraulic head difference between the Crouch Branch and Gordon Aquifers is shown. In this figure, one can see the strong upward gradient along the stretch of Upper Three Runs that gradually diminishes away from the Savannah River. The geometry of this upward gradient provides evidence that groundwater from the upper portion of the Crouch Branch Aquifer actually discharges into Upper Three Runs. A relatively strong upward hydraulic gradient also exists near the Savannah River, which again provides evidence that this is the ultimate regional discharge point for groundwater in this aquifer. 


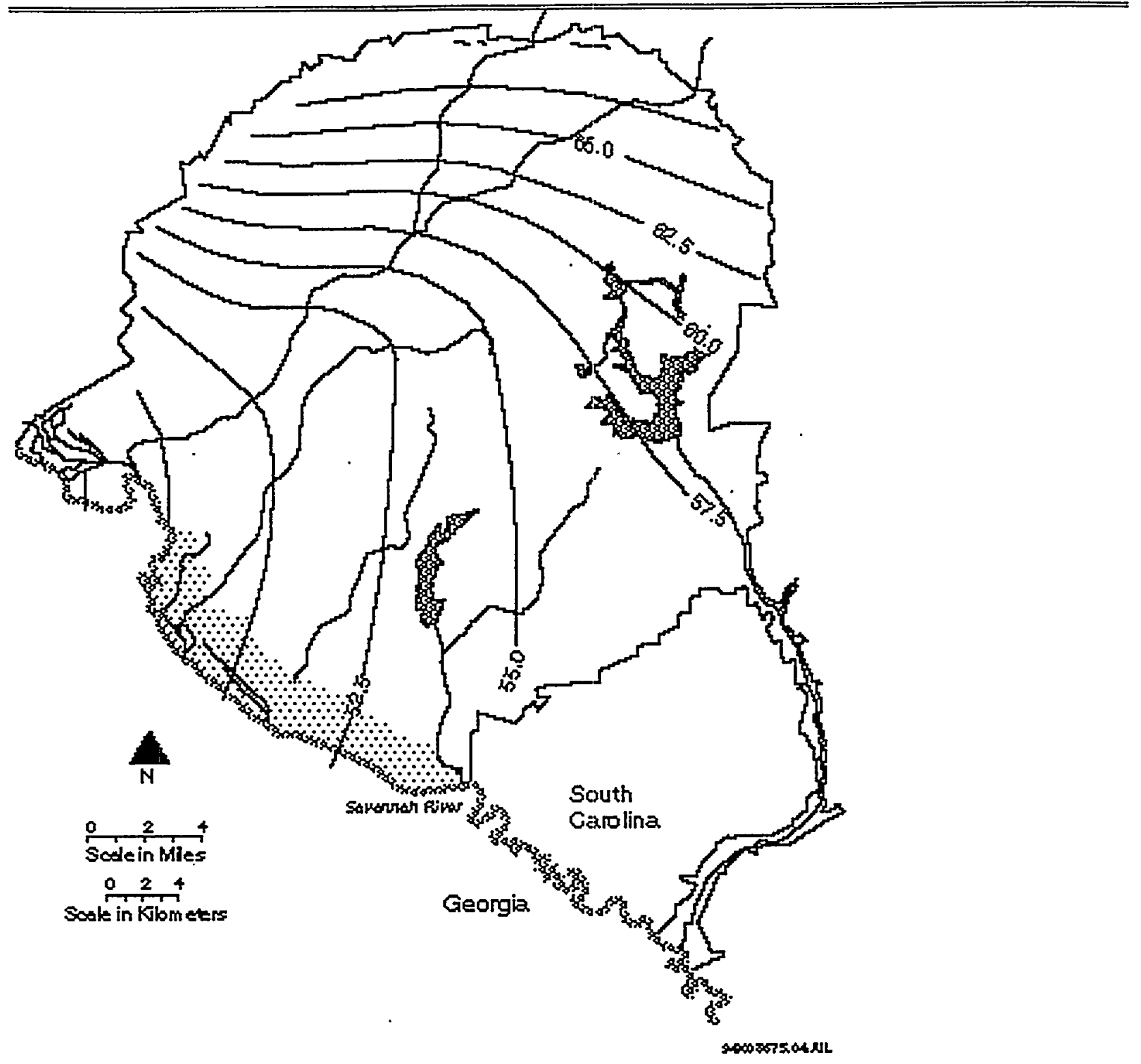

Figure 1-22. Isopotentoimetric map for the McQueeen Branch Aquifer beneath the Savannah River Site (elevations in meters above mean sea level) (Source: Aadland et al. 1992) 

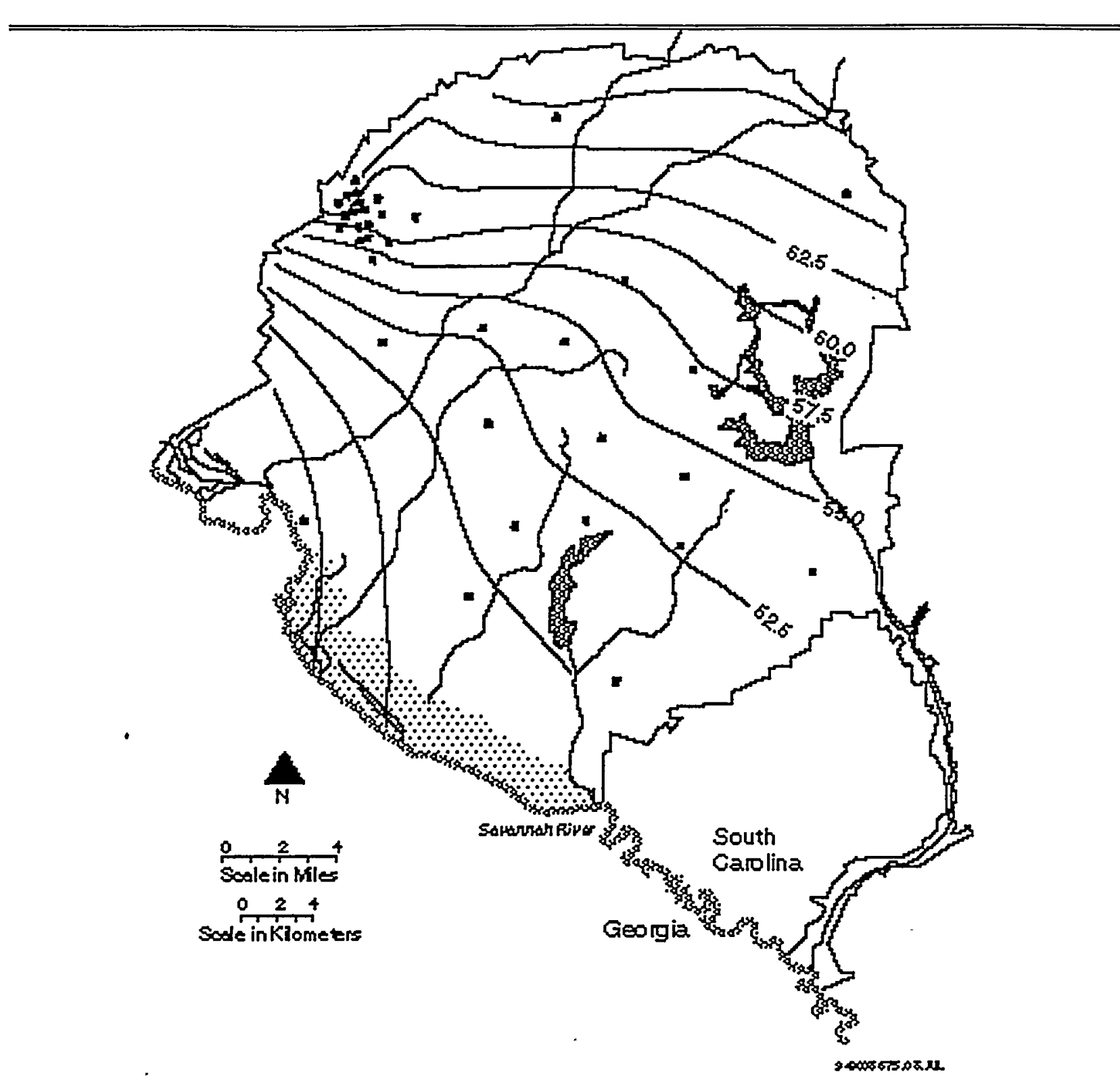

Figure 1-23. Isopotentoimetric map for the Crouch Branch Aquifer beneath the Savannah River Site (elevations in meters above mean sea level) (Source: Aadland et al. 1992) 


\section{GROUNDWATER PROTECTION

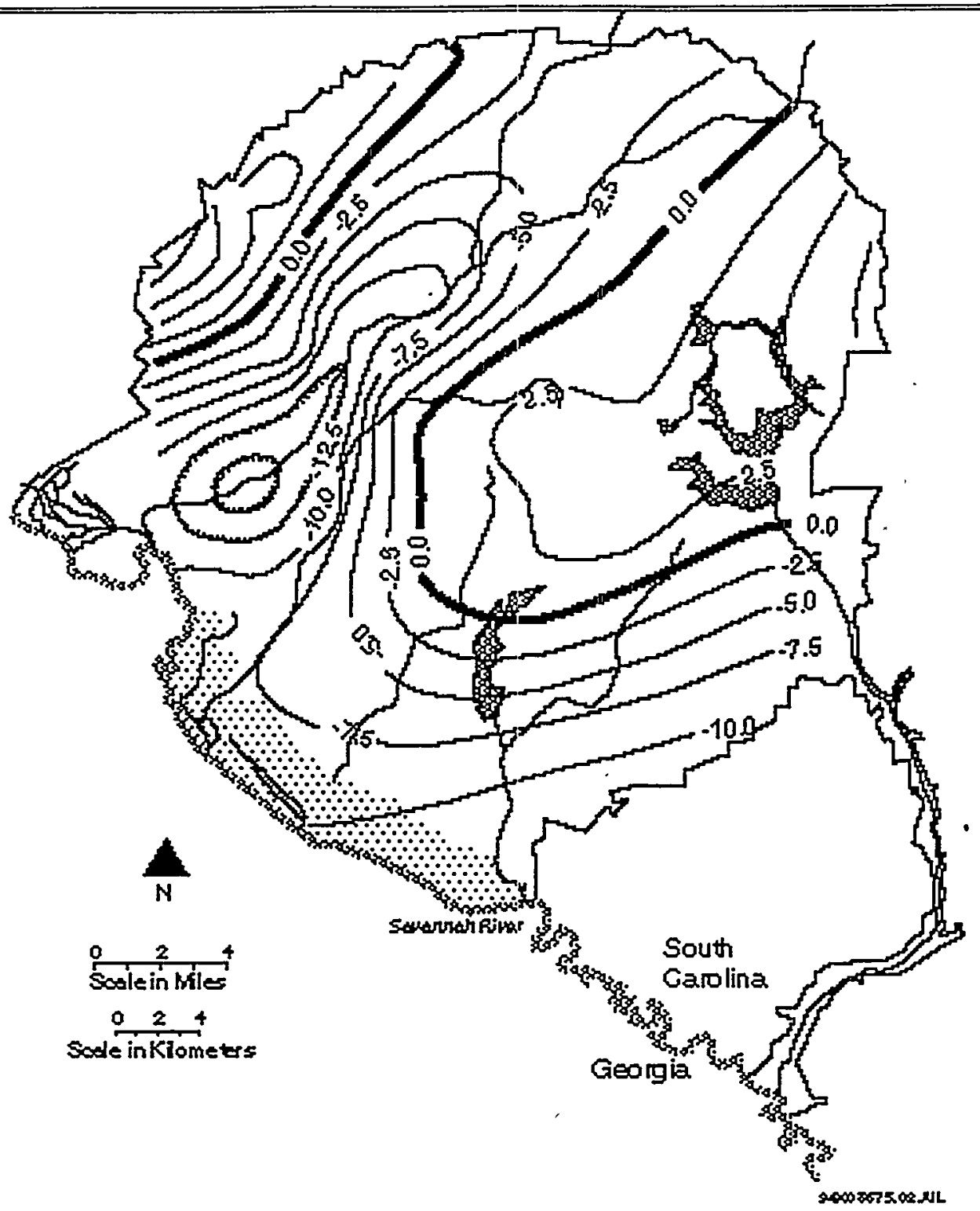

Figure 1-24. Isopotentoimetric map for the Crouch Branch and Gordon Aquifer beneath the Savannah River Site (elevations in meters above mean sea level) (Source: Aadland et al. 1992)

Also in Figure 1-24, the direction of the hydraulic gradient between the Crouch Branch Aquifer and the Gordon Aquifer changes from upward to downward away from the influence of Upper Three Runs Creek. This has often been called "head reversal" in the past. Recently SRS has attempted to avoid this terminology because people not intimately familiar with SRS assumed the "head reversal" was a result of producing water from the Crouch Branch Aquifer. In fact, it is merely a natural phenomenon resulting from the proximity of discharge and recharge areas. The upward hydraulic gradient between the Crouch Branch and Gordon Aquifers is an important factor when considering groundwater contaminant transport. 
The upward gradient helps prevent contamination of the deeper aquifer over a significant fraction of the site and will also tend to transport any contamination that could potentially reach the Crouch Branch Aquifer back towards the Gordon Aquifer. Additionally, the Meyer's Branch confining system retards the flow of contaminants from the Gordon Aquifer to the Crouch Branch Aquifer. All of these features contribute to the general lack of contamination of the deeper aquifers at SRS. There is only a small area near the Savannah River Technology Center that has measurable amounts (on the order of 100 parts per billion) of trichloroethylene in the Crouch Branch Aquifer. Groundwater in this area is flowing away from the site boundary towards the Savannah River.

The Crouch Branch Aquifer is used as a water source in several production areas of the site. New or replacement production wells, by agreement with SCDHEC, will not be completed in this aquifer in order to maintain high potentiometric head within the aquifer.

Floridan Aquifer System

Gordon Aquifer

The Gordon Aquifer has been previously called the Congaree Aquifer, the Tertiary Aquifer, and Aquifer IIA in previous SRS reports. In A/M Area, it has sometimes been divided between the Upper and Lower Congaree, based on observed localized features.

Figure 1-25 is a potentiometric map for the Gordon Aquifer beneath SRS. Horizontal flow in the Gordon Aquifer is towards the Upper Three Runs tributary and the Savannah River, depending upon the area of SRS. Both the Savannah River and Upper Three Runs intercept the Gordon Aquifer. Recharge to the Gordon Aquifer comes predominantly from groundwater that originates on SRS.

Contaminants have been observed in the Gordon Aquifer in the A/M Area (Lost Lake Aquifer Zone of the Steed Pond Aquifer) and the General Separations Area (GSA) of SRS. Contamination in the General Separations Area discharges to Upper Three Runs which is a tributary of the Savannah River. The discharging contamination is thus substantially diluted before reaching the Savannah River. Contaminants in the A/M Area of the Gordon Aquifer have not reached a discharge point.

The Gordon Aquifer is used for minor domestic water production in the vicinity of guard buildings near SRS boundaries. The groundwater is tested regularly from these wells as a precaution even though a potential for contamination is not known to exist. 


\section{GROUNDWATER PROTECTION

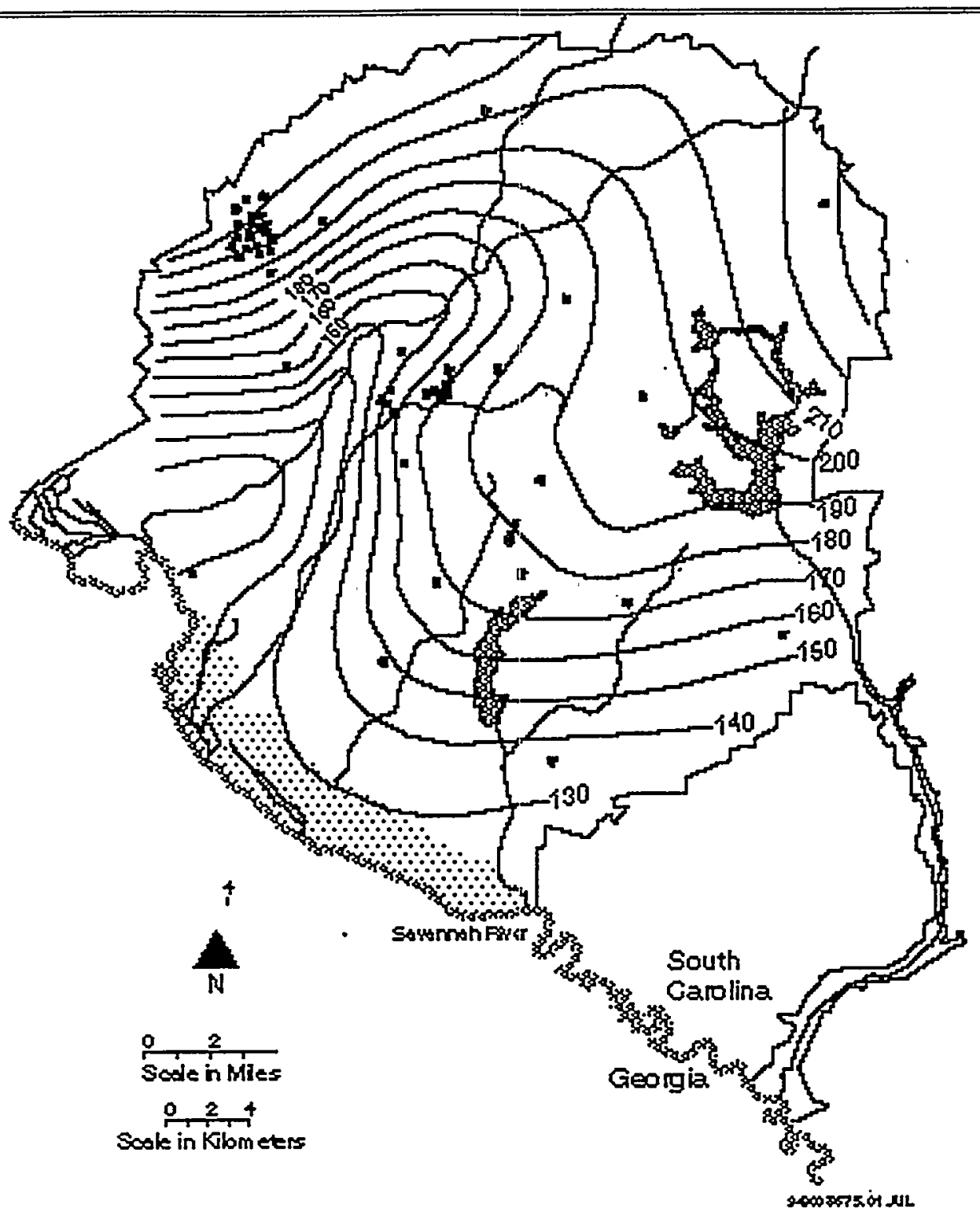

Figure 1-25. Isopotentiometric map for the Gordon Aquifer beneath the Savannh River Site (elevations in meters above mean sea level) (Source: Aadland et al. 1992)

\section{Upper Three Runs Aquifer}

This aquifer has been called the water table aquifer, and has also been separated into the Barnwell/McBean and water table aquifers in the General Separations Area where they were thought to be separated by the "tan clay". This is the most shallow aquifer at SRS. 
An isopotentiometric map for the Upper Three Runs Aquifer (the water table aquifer) is shown in (Figure 1-26). The horizontal groundwater flow is generally towards the nearest surface water feature that is in communication with the water table. Most of the SRS streams are in communication with the water table, with the exception of Tim's Branch near the northern part of A/M Area. In this area, Tim's Branch is a "losing stream", meaning it provides, or "loses", recharge to the vadose zone above the Upper Three Runs Aquifer. The Upper Three Runs Aquifer predominantly receives recharge through precipitation, as one would expect.

In the AM Area the flow in Upper Three Runs Aquifer is mainly downward given its relatively large distance from a discharge point (Figure 1-27). In other portions of the site, there is a balance between horizontal and vertical flow, but the groundwater is close enough to a stream that it discharges to the stream before it reaches the underlying Gordon Aquifer. In Figure 1-27, a strong downward vertical gradient towards the Gordon Aquifer is evident over much of the site. However, this is a result of a localized feature that has been called the "tan clay." This local leaky aquitard supports a large hydraulic head difference resulting in a pronounced downward gradient on a local basis. However, this same aquitard also retards the vertical flow of groundwater because of its low permeability. Groundwater beneath the "tan clay' is contaminated beneath some of the seepage basins that were used in the past at the GSA.

In areas where the Gordon Aquifer discharges (along Upper Three Runs Creek and the Savannah River), a significant upward gradient exists which prevent any contamination in the Upper Three Runs Aquifer from migrating downward (Figure 1-27). This is an important feature in D Area, TNX, and the Sanitary Landfill, for example.

Because the Upper Three Runs Aquifer is the most shallow aquifer, it is also the most important aquifer as far as contaminant transport. This aquifer has been studied on a very localized basis at a number of waste sites at SRS. The best data on the Upper Three Runs Aquifer is available in reports on these waste sites. In the absence of specific local information, the regional isopotentiometric map is a good starting point for estimating the direction of groundwater flow.

Upper Three Runs Aquifer is not used for a source of domestic or production water on SRS, because the lower aquifers are more prolific in terms of their ability to transmit water and they consistently produce higher quality water.

\section{Unsaturated (Vadose) Zone Groundwater Flow}

\section{Introduction}

The water table is a major hydrogeologic feature in the subsurface. Below the water table, the pores between the sediment grains are completely filled with water, i.e., the sediments are saturated with water or simply "saturated," with the reference to water being implied. Above the water table, the pores are filled with a variable mixture of air and water, i.e., the sediments are unsaturated. The region above the water table is thus called the unsaturated zone. It is also called the vadose zone.

Water in the vadose zone generally exists at a pressure which is less than atmospheric pressure. This occurs because of the attraction which exists between water and the surfaces of sediment grains. This attraction creates a capillary force which acts to hold water in place in the porous sediments. The smaller the pores (i.e., the finer the grains) the stronger is this capillary force. Thus fine-grain sediments like clays will generally tend to retain more water under unsaturated conditions than will coarser-grained sediments, that is finer-grained sediments generally are more saturated than coarser sediments, which drain more quickly. 


\section{GROUNDWATER PROTECTION \\ MANAGEMENT PROGRAM}

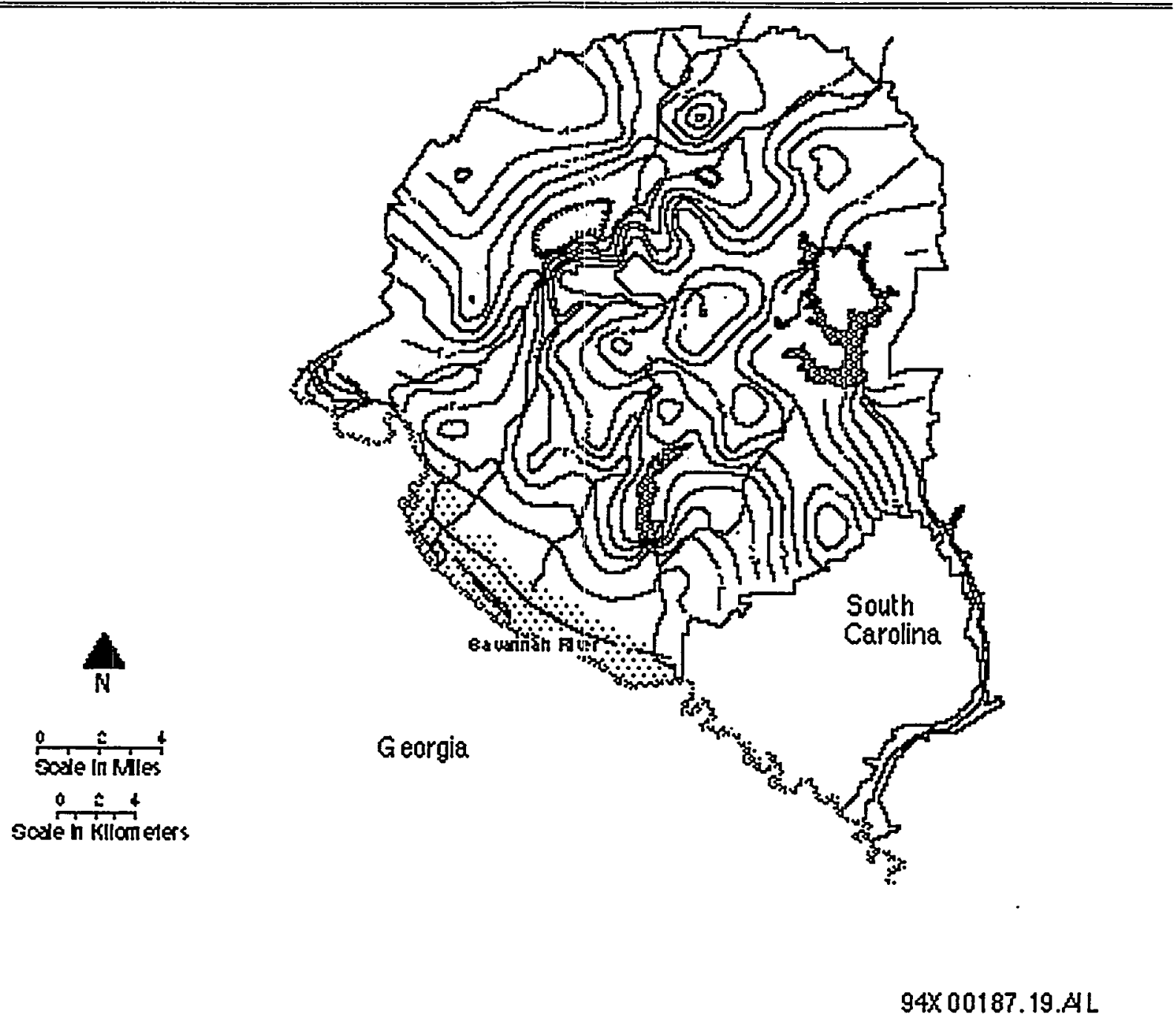

Figure 1-26. Water table map for the Savannah River Site 


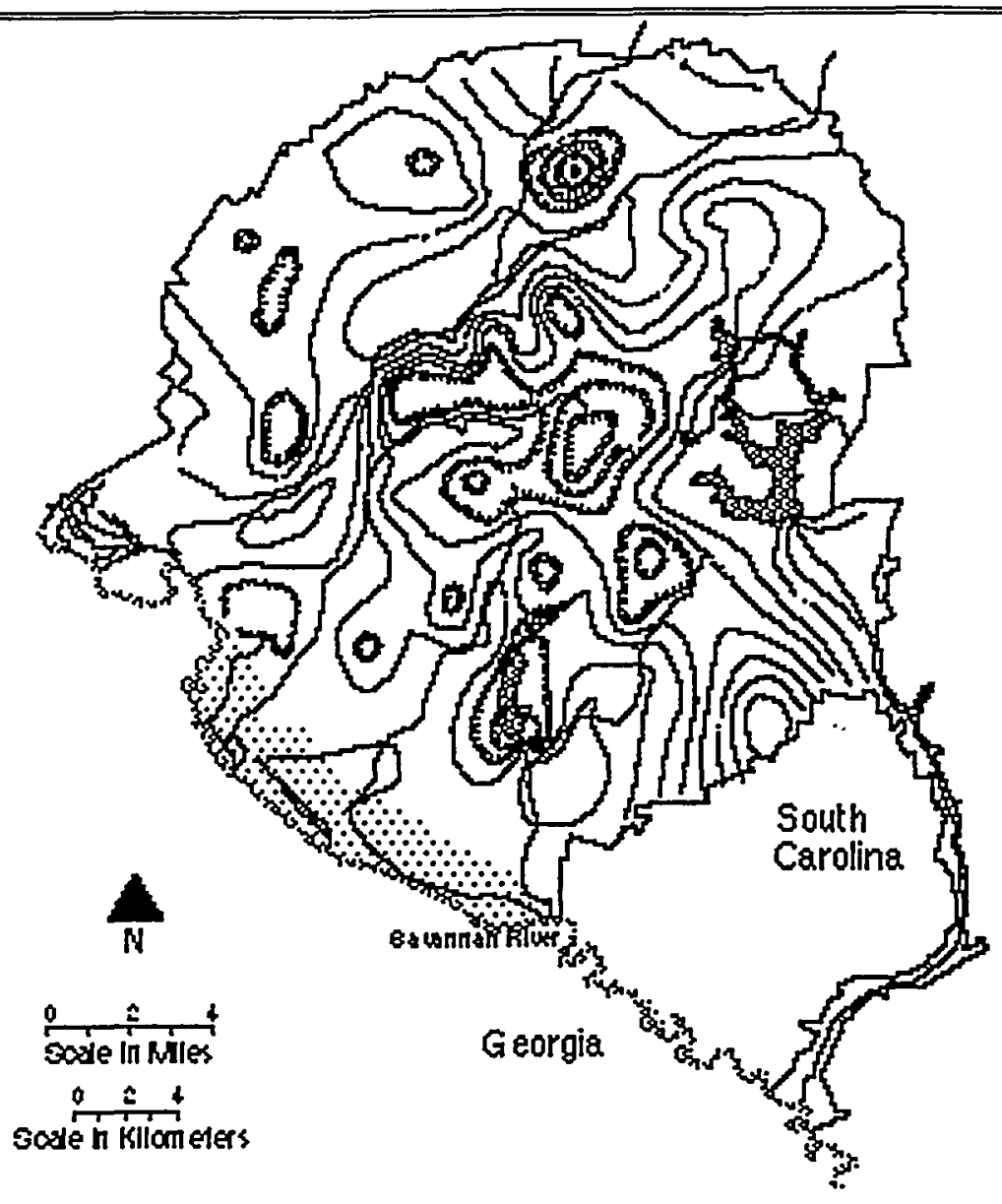

$94 \times 00187.18 . \mathrm{AL}$

Figure 1-27. Hydraulic head difference between the Upper Three Runs and Gordon Aquifers (elevations in meters above mean sea level; negative values indicate the areas of upward flow from the Crouch Branch into shallower zones) (Source: Aadland et al. 1992)

The patterns of water flow in unsaturated or vadose zone sediments can be quite different from what one would expect in saturated sediments because of the capillary force and water saturation effects. This occurs because permeability is directly related to water saturation in unsaturated or vadose zone sediments. Water flow rates can be faster in fine-grained sediments relative to coarse-grained sediments because of this phenomenon. This is the opposite behavior of what occurs below the water table where water flow occurs more readily in coarse-grained layers. 
Recharge

The main source of recharge to the water table aquifer is rainfall (and occasionally snow melt) which seep into the ground through the vadose zone. Annual rainfall at SRS averages approximately 122 $\mathrm{cm}$ (48 in., Hubbard 1986). There is a seasonal pattern to the rainfall with January through March receiving higher amounts of rain and October through December receiving lower rainfall. Hubbard (1986) also provides an estimate of the annual water budget of precipitation based on lysimeter studies performed in the General Separations Area. In bare soil and grass covered areas, Hubbard estimated that the $122 \mathrm{~cm}$ (48 in.) of precipitation can be partitioned as $40.7 \mathrm{~cm}$ (16 in.) to subsurface recharge, $5.1 \mathrm{~cm}(2 \mathrm{in}$.) to runoff to local streams, and $76.2 \mathrm{~cm}$ (30 in.) to evapotranspiration. In forested areas, Hubbard estimated that evapotranspiration increases to $102 \mathrm{~cm}$ (40 in.) and recharge decreases to approximately $15.2 \mathrm{~cm}$ (6 in.) The large increase in evapotranspiration for forested areas can be attributed to the large transpiration potential of pines, such as loblolly.

Direction of Groundwater Flow in the Vadose Zone

The direction of groundwater flow in the vadose zone is predominantly downward. However, lenses of silt and clay may cause significant lateral spread in some areas. The extent of lateral spreading can be estimated by examining tritiated water in the unsaturated zone; one should use caution in using other contaminant data due to the chemical interactions between the contaminant and the soil, which effect how different contaminants move with the unsaturated flow, and the lateral spread that can occur in multi-component flow such as with solvents.

As a result of the complex, layered hydrogeology of the site, perched water does exist in several areas. Therefore, one must be careful interpreting information from water table wells by observing whether hydraulic head is consistent with the water table map for SRS (Figure 1-26). In the absence of perched water, the vadose zone thickness ranges from approximately $40 \mathrm{~m}(130 \mathrm{ft})$ in the northern-most portion of the site (A/M Area) to $0 \mathrm{~m}$ where the water table intersects wetlands, streams, or creeks.

\subsubsection{Aquifer Characteristics}

\subsubsection{Piedmont Hydrogeologic Province}

Marine (1967a, 1973) reported representative hydraulic conductivity values of $4 \times 10^{-5} \mathrm{ft} /$ day $(1.2 \mathrm{x}$ $10^{-5} \mathrm{~m} /$ day) for the "virtually impermeable rocks" and $0.1 \mathrm{ft} /$ day $(0.03 \mathrm{~m} /$ day $)$ for the "hydraulically transmissive rocks". Analysis of a two-well tracer test indicates a fracture porosity of 0.08 in a hydraulically transmissive fracture zone (Marine 1967). Laboratory analyses of cores indicate an average intergranular porosity of 0.13 (Webster et al. 1970).

In the Dunbarton Basin, groundwater is present in the porosity of the clastic rocks. However, the hydraulic conductivity is extremely low, and water movement is almost nonexistent. The hydraulic conductivity of the Triassic sedimentary rock, as determined from field tests, ranges from $10^{-5}$ to $10^{-}$ $8 \mathrm{ft} /$ day $\left(10^{-6}\right.$ to $10^{-9} \mathrm{~m} /$ day) (Marine 1974). The average total porosity is $8.0 \%$ for sandstones and $3.3 \%$ for mudstones. Average effective porosity is $7.0 \%$ for sandstones and $0.53 \%$ for mudstones.

Water is not pumped from rocks in the Dunbarton Basin, nor is there likely to be any pumped in the future because of the poor water quality and low conductivity of the rocks. 


\subsubsection{Southeastern Coastal Plain Hydrogeologic Province}

\subsection{Aquifer Systems of the Southeastern Coastal Plain}

\section{Midville Aquifer System}

The McQueen Branch Aquifer on the SRS is a portion of the regional Midville Aquifer System. Porosity values for sands from the Midville Aquifer, calculated from median grain size (Beard and Weyl 1973) and sorting (Trask 1930), average $32.3 \pm 2.1 \%$ and range from 30.3 to $34.8 \%$ (Aadland et al. 1994). Calculated conductivity values (Beard and Weyl 1973) for five sands range from 5 to 240 $\mathrm{ft} /$ day ( 1.5 to $73 \mathrm{~m} /$ day); geometric mean conductivity of the five samples is $50.9 \mathrm{ft} /$ day ( $15.5 \mathrm{~m} /$ day).

Horizontal hydraulic conductivity in the Midville and Dublin-Midville Aquifer Systems was estimated at 24 wells by dividing the observed transmissivity by the total open interval in the well (Clarke et al. 1985). Values ranged from 15 to $530 \mathrm{ft} /$ day (4.6 to $161 \mathrm{~m} /$ day). Yields exceeding 1,000 $\mathrm{gal} / \mathrm{min}$ ( $4.4 \mathrm{~m}^{3} / \mathrm{min}$ ) are observed from wells tapping the Dublin Aquifer System in Laurens and Screven Counties; the Midville Aquifer System in Houston County; and the Dublin-Midville Aquifer System in Twiggs, Washington, Willkinson, and Jefferson Counties. Multi-aquifer wells tapping both the Dublin and the Midville Aquifer Systems in Houston and Burke Counties also have been reported to yield more than $1000 \mathrm{gal} / \mathrm{min}\left(4.4 \mathrm{~m}^{3} / \mathrm{min}\right.$, Clarke et al. 1985).

\section{Dublin Aquifer System}

The regional Dublin Aquifer System is the Crouch Branch Aquifer on the SRS. Few data are available for the system outside of SRS. The transmissivity in the Crouch Branch Aquifer is relatively high because of the coarse sand and low clay content of the aquifer.

Bledsoe et al. (1990) measured the porosity and conductivity of several sand and mud samples (silty clays and sandy clays) from the Crouch Branch Aquifer. Mean porosity of two muddy-sand samples was $38.5 \pm 7.5 \%$, and the geometric mean conductivity (vertical) was $1.25 \times 10^{-6} \mathrm{ft} /$ day $\left(3.8 \times 10^{-7}\right.$ $\mathrm{m} /$ day). One horizontal conductivity measurement yielded a value of $1.46 \times 10^{-2} \mathrm{ft} /$ day $\left(4.5 \times 10^{-3}\right.$ $\mathrm{m} /$ day). The average porosity of seven intra-aquifer mud layers (silty clays and sandy clays) was 35.9 $\pm 2.5 \%$, and the geometric mean vertical conductivity was $1.10 \times 10^{-8} \mathrm{ft} /$ day $\left(3.4 \times 10^{-9} \mathrm{~m} /\right.$ day $)$. The geometric mean of six horizontal conductivity measurements on the intra-aquifer mud samples was $1.21 \times 10^{-3} \mathrm{ft} /$ day $\left(3.69 \times 10^{-4} \mathrm{~m} /\right.$ day $)$.

The water-bearing properties of the aquifer system tend to deteriorate to the southeast. Zack (1977) reported values for transmissivity ranging from 390 to $5,350 \mathrm{ft}^{2} /$ day (36 to $497 \mathrm{~m}^{2} /$ day) in Horry and Georgetown Counties. In Charleston County, Park (1980) calculated a value of about $1,200 \mathrm{ft}^{2} /$ day (110 $\mathrm{m}^{2} /$ day). Calculated transmissivity used to model the Dublin Aquifer System in South Carolina ranges from 400 to $11,000 \mathrm{ft}^{2} /$ day ( 37 to $1020 \mathrm{~m}^{2} /$ day, Aucott 1988). 
Dublin-Midville Aquifer System

Introduction

The Dublin-Midville Aquifer System underlies the central part of the SRS. It can be thought of as a combination of the McQueen Branch and Crouch Branch Aquifers.

Hydrologic data for the Dublin-Midville Aquifer System and the lower part of the Meyers Branch confining system are listed in (Table 1-2). Transmissivity values and storage coefficients were determined from pump-test results obtained in 1951 and 1952 (Siple 1967). The Theis nonequilibrium and the Cooper-Jacob straight-line methods were used to analyze the data from the tests in which measurements were obtained in one or more observation wells. The average transmissivity value was $1.58 \times 10^{4} \mathrm{ft}^{2} /$ day $\left(14.7 \mathrm{~m}^{2} /\right.$ day), and the median was $1.47 \times 10^{4} \mathrm{ft}^{2} /$ day $\left(1.36 \times 10^{3} \mathrm{~m}^{2} /\right.$ day) for the Dublin-Midville Aquifer System.

The Theis recovery formula was used to analyze the data from tests in which measurements were made only in the pumped well (Siple 1967). The storage coefficients ranged from $3 \times 10^{-4}$ to $7 \times 10^{-4}$ for the confined aquifers of the Dublin-Midville Aquifer System (Table 1-2).

Table 1-2. Hydrologic Data for the McQueen Branch and Crouch Branch Aquifers (Modified from Aadland et al. 1992).

\begin{tabular}{|l|l|l|l|c|c|c|c|c|}
\hline Aquifer Unit & $\begin{array}{c}\text { Date } \\
\text { Sampled }\end{array}$ & $\begin{array}{c}\text { Pumped } \\
\text { Well }\end{array}$ & $\begin{array}{c}\text { Well } \\
\text { Observed }\end{array}$ & $\begin{array}{c}\text { Average } \\
\text { Pumping } \\
\text { Rate } \\
\left(\mathrm{m}^{3} / \mathrm{min}\right)\end{array}$ & $\begin{array}{c}\text { Sand } \\
\text { Thickness } \\
(\mathrm{m}) \text { Trans- } \\
\text { missivity } \\
\left(\mathrm{m}^{2} / \text { day) }\right.\end{array}$ & $\begin{array}{c}\text { Hydraulic } \\
\text { Conductivit } \\
\text { y (m/day) }\end{array}$ & $\begin{array}{c}\text { Storage } \\
\text { Co- } \\
\text { efficien } \\
t\end{array}$ \\
\hline Crouch Br. & $09 / 20 / 51$ & $25-\mathrm{P}$ & $25-\mathrm{P}$ & 2.04 & 66.8 & 790 & 11.8 & \\
\hline Crouch Br. & $11 / 03 / 51$ & $30-\mathrm{P}$ & $30-\mathrm{P}$ & 2.04 & 43.9 & 647 & 14.7 & \\
\hline Crouch Br. & $8 / 10 / 52$ & $27-\mathrm{R}$ & $105-\mathrm{R}$ & 1.66 & 31.4 & 1,119 & 35.7 & 0.0004 \\
\hline Crouch Br. & $12 / 31 / 51$ & $33-\mathrm{K}$ & $33-\mathrm{K}$ & 2.18 & 46.9 & 1,356 & 28.9 & \\
\hline Crouch Br. & $5 / 26 / 52$ & $51-\mathrm{C}$ & $51-\mathrm{C}$ & 2.23 & & 1,181 & & \\
\hline Crouch Br. & $6 / 16 / 52$ & $52-\mathrm{C}$ & $52-\mathrm{C}$ & 2.14 & 41.5 & 1,741 & 42.0 & \\
\hline Crouch Br. & $8 / 3 / 52$ & $25-\mathrm{P}$ & $105-\mathrm{P}$ & 1.40 & 66.8 & 572 & 8.6 & 0.0004 \\
\hline Crouch Br. & $11 / 28 / 51$ & $29-\mathrm{L}$ & $29-\mathrm{L}$ & 1.98 & 37.8 & 883 & 23.4 & \\
\hline Crouch Br. & $4 / 23 / 51$ & $15-\mathrm{M}$ & $15-\mathrm{M}$ & 1.70 & 48.8 & 417 & 8.5 & \\
\hline McQueen Br. & $4 / 28 / 52$ & $49-\mathrm{F}$ & $49-\mathrm{F}$ & 2.12 & 81.4 & 1,306 & 16.0 & \\
\hline McQueen Br. & $11 / 16 / 51$ & $21-\mathrm{F}$ & $24-\mathrm{F}$ & 7.07 & 72.2 & 3,134 & 43.4 & 0.0007 \\
\hline McQueen Br. & $5 / 8 / 52$ & $35-\mathrm{H}$ & $35-\mathrm{H}$ & 5.10 & 83.2 & 2,437 & 29.3 & \\
\hline McQueen Br. & $1 / 3 / 52$ & $35-\mathrm{H}$ & $35-\mathrm{H}$ & 2.12 & 83.2 & 2,462 & 29.6 & \\
\hline McQueen Br. & $2 / 23 / 52$ & $43-\mathrm{H}$ & $43-\mathrm{H}$ & 2.12 & 84.4 & 2,537 & 30.0 & \\
\hline McQueen Br. & $5 / 6 / 52$ & $48-\mathrm{H}$ & $48-\mathrm{H}$ & 2.27 & 79.2 & 2,462 & 31.1 & \\
\hline McQueen Br. & $3 / 17 / 52$ & $44-\mathrm{H}$ & $44-\mathrm{H}$ & 2.15 & 72.8 & 4,664 & 64.0 & \\
\hline McQueen Br. & $2 / 29 / 52$ & $37-\mathrm{F}$ & $37-\mathrm{F}$ & 2.23 & 64.9 & 2,214 & 34.1 & \\
\hline McQueen Br. & $1 / 19 / 52$ & $31-\mathrm{M}$ & $4-\mathrm{M}, 20-\mathrm{M}$ & 5.67 & 55.2 & 1,828 & 33.1 & 0.0003 \\
\hline
\end{tabular}

McQueen Branch Aquifer Unit 
Porosity values for $64 \mathrm{McQueen}$ Branch sands containing less than $25 \%$ mud were calculated from median grain size (Trask 1930) and sorting (Beard and Weyl 1973). The average was $32.6 \pm 2.7 \%$, and values ranged from 26.6 to $38.7 \%$ (Aadland et al. 1994). The calculated porosity values appears to follow a normal distribution (Aadland et al. 1994). Calculated hydraulic conductivity values (Beard and Weyl 1973) of these sands ranged from 12.3 to $416 \mathrm{ft} /$ day $(3.75$ to $127 \mathrm{~m} /$ day) (Aadland et al. 1994). The geometric mean conductivity of the 67 sand samples was $107 \mathrm{ft} /$ day $(32.6 \mathrm{~m} /$ day). Calculated hydraulic conductivity values of the McQueen Branch sands were skewed toward high values (Aadland et al. 1994), and appear to follow a log-normal distribution (Aadland et al. 1994).

Bledsoe et al. (1990) analyzed three sandy-mud samples from intra-aquifer confining layers for porosity and conductivity. The mean porosity was $29.3 \pm 3.5 \%$. The geometric mean conductivities are: $1.17 \times 10^{-8} \mathrm{ft} /$ day (vertical, $3.57 \times 10^{-9} \mathrm{~m} /$ day) and $2.68 \times 10^{-4} \mathrm{ft} /$ day (horizontal, $8.17 \times 10^{-5}$ $\mathrm{m} /$ day).

Wells screened in the McQueen Branch Aquifer are commonly screened in the overlying Crouch Branch Aquifer as well. The lack of data exclusively for the McQueen Branch Aquifer makes determination of hydraulic characteristics difficult (Logan and Euler 1989). Because of the similarity in lithology, water levels, water quality, and the almost identical response of the water levels in both aquifers to applied stress in the up-dip areas (northeast of the Aiken-Barnwell County line at SRS), the two aquifers are considered part of the same hydrogeologic system, namely the Dublin-Midville Aquifer System.

Based on three pumping tests in the McQueen Branch Aquifer, two pumping tests in F Area, and one in L Area, transmissivity estimates range from 12,000 to $24,000 \mathrm{ft}^{2} /$ day (1100 to $2200 \mathrm{~m}^{2} /$ day) with an average transmissivity of $16,000 \mathrm{ft}^{2} /$ day $\left(1500 \mathrm{~m}^{2} /\right.$ day) (GeoTrans 1988). Off-site transmissivity measurements also fall within this range. Simulated transmissivity values from the (Aucott 1988) regional model are within the same order of magnitude, $\sim 10^{4} \mathrm{ft}^{2} /$ day $\left(\sim 3 \times 10^{3} \mathrm{~m}^{2} /\right.$ day $)$. Hydraulic conductivity estimates range from 41 to $290 \mathrm{ft} /$ day (12 to $88 \mathrm{~m} /$ day) in F Area and approximately 93 $\mathrm{ft} /$ day (28 $\mathrm{m} /$ day) in L Area. Siple (1967) obtained seven storage coefficient estimates for the "Tuscaloosa Aquifer" ranging from 0.0004 to 0.0008 and averaging 0.00042 . The "Tuscaloosa" as defined by Siple included both the McQueen Branch and the Crouch Branch Aquifers.

A seven-day pumping test was conducted at the Barnwell Nuclear Fuel Plant (BNFP) adjacent to SRS during the spring and summer of 1971. A 10-inch production well and an observation well were completed in the McQueen Branch Aquifer. The pumping well produced more than 3,000 gpm (13 $\mathrm{m}^{3} / \mathrm{min}$ ) during development. For the pumping test, discharge from the well was maintained at a constant rate of $1,400 \mathrm{gpm}\left(6.1 \mathrm{~m}^{3} / \mathrm{min}\right)$. Water levels were monitored in the pumping well and indicated a specific capacity of $30 \mathrm{gpm} / \mathrm{ft}\left(0.43 \mathrm{~m}^{3} / \mathrm{min} / \mathrm{m}\right)$. Water level data from the observation well indicated a transmissivity of about $19,000 \mathrm{ft}^{2} /$ day $\left(1800 \mathrm{~m}^{2} /\right.$ day $)$ and a storage coefficient of 0.00025 . Wells completed in the McQueen Branch Aquifer just five miles west of the test site in and near the General Separations Area commonly have specific capacities between 40 and $60 \mathrm{gpm} / \mathrm{ft}$ ( 0.58 and $0.87 \mathrm{~m}^{3} / \mathrm{min} / \mathrm{m}$ ). The values for transmissivity are also much higher.

\section{McQueen Branch Confining Unit}

Bledsoe et al. (1990) measured the porosity and hydraulic conductivity of six mud samples (silty clays and sandy clays) from the McQueen Branch Confining Unit. The mean porosity of the six samples was $43.0 \pm 5.8 \%$ and the geometric mean vertical hydraulic conductivity measurements was $5.01 \mathrm{x}$ 
$10^{-8} \mathrm{ft} /$ day $\left(1.53 \times 10^{-8} \mathrm{~m} /\right.$ day). The geometric mean conductivity of two horizontal conductivity measurements are $1.47 \times 10^{-3} \mathrm{ft} /$ day $\left(4.48 \times 10^{-4} \mathrm{~m} /\right.$ day $)$.

Few data are available on the hydraulic properties of the McQueen Branch Confining Unit. In much of the area north and west of the Aiken/Barnwell County line, the Crouch Branch Aquifer contributes downward leakage into the McQueen Branch Aquifer. Simulated leakage coefficients (Aucott 1988) range from $10^{-4} /$ day to $10^{-8} /$ day. The leakage coefficients ranging from $10^{-6} /$ day to $10^{-}$ $8 /$ day define a band along the lower half of the site (where the Allendale confining system is defined). Leakage coefficients ranging from $10^{-4}$ to $10^{-6}$ / day are found in the upper half of the site (where the McQueen Branch Confining Unit is defined).

Vertical hydraulic conductivity estimates used by GeoTrans (1989) ranged from $0.06 \mathrm{ft} /$ day to 1.0 $\mathrm{ft} /$ day $(0.018$ to $0.30 \mathrm{~m} /$ day). Assuming a thickness of 100 to $200 \mathrm{ft}(30$ to $60 \mathrm{~m}$ ), the leakage coefficient would be approximately $3 \times 10^{-4} /$ day to $1 \times 10^{-2} /$ day. These values are above or near the upper limit of those reported by Aucott (1988).

Crouch Branch Aquifer Unit

Bledsoe et al. (1990) measured the porosity and conductivity of 16 sand and mud samples (silty clays and sandy clays) from the Crouch Branch Aquifer. Mean porosity of three muddy-sand samples is $35.7 \pm 1.8 \%$, with a geometric mean conductivity (vertical) of $6.16 \times 10^{-8} \mathrm{ft} /$ day $\left(1.88 \times 10^{-8} \mathrm{~m} /\right.$ day) The geometric mean of two horizontal conductivity rneasurements is $4.16 \times 10^{-3} \mathrm{ft} /$ day $\left(1.27 \times 10^{-3}\right.$ $\mathrm{m} /$ day). The average porosity of 13 samples from intra-aquifer muddy layers (silty clays and sandy clays) is $35.5 \pm 1.2 \%$; geometric mean conductivity (vertical) is $5.89 \times 10^{-8} \mathrm{ft} /$ day $\left(1.80 \times 10^{-8} \mathrm{~m} /\right.$ day). The geometric mean of 11 horizontal conductivity measurements on the same mud samples is $5.56 \mathrm{x}$ $10^{-6} \mathrm{ft} /$ day $\left(1.69 \times 10^{-6} \mathrm{~m} /\right.$ day $)$.

The Crouch Branch Aquifer is persistent throughout the northern half of the study area and is the principal water-producing aquifer at SRS. Transmissivity values in the Crouch Branch Aquifer are relatively high because of the coarse sand and low clay content of the aquifer. To the south, in the lower Coastal Plain, the hydraulic conductivity and transmissivity in the down-dip equivalent of the Crouch Branch, namely the Dublin.Aquifer System, appears to be much lower probably due to the presence of the Gulf Trough (Aucott et al. 1987).

Hydraulic properties for the Crouch Branch Aquifer were determined using inverse modeling techniques by (GeoTrans 1988). These data are presented in (Table 1-3). The lowest transmissivity, $3,000 \mathrm{ft}^{2} /$ day ( $280 \mathrm{~m}^{2} /$ day), was in $\mathrm{K}$ Area; the highest transmissivity, $27,000 \mathrm{ft}^{2} /$ day ( $2500 \mathrm{~m}^{2} /$ day), was in D Area. The majority of transmissivity values were between 10,000 and $20,000 \mathrm{ft}^{2} / \mathrm{day}$ (3000 and $6000 \mathrm{~m}^{2} /$ day). According to Logan and Euler (1989), wells near the center of SRS were test pumped at various rates and had specific capacities that ranged from 3.5 to $38 \mathrm{gpm} / \mathrm{ft}(0.051$ to 0.55 $\mathrm{m}^{3} / \mathrm{min} / \mathrm{m}$ ). Pumping tests at these wells indicated an average transmissivity of $12,000 \mathrm{ft}^{2} /$ day (1100 $\mathrm{m}^{2} /$ day) and a storage coefficient of 0.0004 . All other storage coefficient estimates, as well as effective porosity estimates, were calculated for the "Tuscaloosa Aquifer" as defined by (Siple 1967) with no differentiation between the currently recognized McQueen Branch and the Crouch Branch Aquifers.

Few wells are screened entirely within the Crouch Branch Aquifer in A/M Area, thus little hydraulic data are available. An aquifer pumping test was conducted by Geraghty and Miller (1983) within the undifferentiated McQueen Branch-Crouch Branch Aquifers in A/M Area. The pumping test 
established representative values for the hydraulic properties of the two aquifers. The transmissivity is estimated at $590,000 \mathrm{ft}^{2} / \mathrm{day}\left(55,000 \mathrm{~m}^{2} /\right.$ day), the storage coefficient is calculated to be $4.2 \times 10^{-4}$, and leakance value is $8.2 \times 10^{-3} /$ day (Geraghty and Miller 1983).

Floridan Aquifer System

Gordon Aquifer Unit

Porosity and conductivity of 382 Gordon Aquifer sands were determined from sieve analyses (Aadland et al. 1994) using the empirical method of Beard and Weyl (1973), based on median grain size and sorting (Trask 1930). The mean porosity of Gordon sands is $35.1 \pm 2.5 \%$; porosity ranges from 27.3 to $40.2 \%$ (Aadland et al. 1994). The distribution of calculated porosity values is slightly skewed toward lower values. Hydraulic conductivity values, calculated using the method of Beard and Weyl (1973), range from 5.5 to $600 \mathrm{ft} /$ day (1.7 to $180 \mathrm{~m} /$ day); $75 \%$ of the hydraulic conductivity values fall between 44 and $350 \mathrm{ft} /$ day (13 and $107 \mathrm{~m} /$ day) (Aadland et al. 1994). The geometric mean hydraulic conductivity of the 382 sand samples was $108 \mathrm{ft} /$ day $(32.9 \mathrm{~m} /$ day). Calculated hydraulic conductivity values of Gordon Aquifer sands are skewed toward high values, and appear to follow a log-normal distribution (Aadland et al. 1994).

Bledsoe et al. (1990) measured the porosity and conductivity of 13 samples from the Gordon Aquifer. Mean porosity of the six muddy-sand samples was $41.3 \pm 3.0 \%$, and the geometric mean vertical hydraulic conductivity was $8.43 \times 10^{-7} \mathrm{ft} /$ day $\left(2.57 \times 10^{-7} \mathrm{~m} /\right.$ day) (Aadland et al. 1994). The geometric mean of five horizontal conductivity measurements on these muddy-sand samples was $0.243 \mathrm{ft} /$ day $(0.0131 \mathrm{~m} /$ day $)$. The average porosity of the seven mud samples from the Gordon Aquifer was $45.0 \pm$ $3.2 \%$. The geometric mean vertical hydraulic conductivity was $2.16 \times 10^{-8} \mathrm{ft} /$ day $\left(6.58 \times 10^{-9} \mathrm{~m} /\right.$ day $)$. The geometric mean of five horizontal conductivity measurements on the same samples was $2.72 \mathrm{x}$ $10^{-3} \mathrm{ft} /$ day $\left(8.29 \times 10^{-4} \mathrm{~m} /\right.$ day $)$.

The sand beds of the Gordon Aquifer make it a productive aquifer. Municipal wells at Barnwell, South Carolina, yield as much as $400 \mathrm{gpm}\left(1.8 \mathrm{~m}^{3} / \mathrm{min}\right)$ with $40 \mathrm{ft}(12 \mathrm{~m})$ of drawdown. Maximum yields of $660 \mathrm{gpm}\left(2.91 \mathrm{~m}^{3} / \mathrm{min}\right)$ with $50 \mathrm{ft}(15 \mathrm{~m})$ of drawdown have been obtained near the center of SRS (Siple 1967). Up-dip, in the northwestern part of SRS, the Gordon Aquifer includes mostly clayey sands, and well yields are not nearly as high. Wells in this area generally produce 20-30 gpm $\left(0.088\right.$ to $\left.0.13 \mathrm{~m}^{3} / \mathrm{min}\right)$ with about $30 \mathrm{ft}(9.1 \mathrm{~m})$ of drawdown. This is sufficient, however, for some light industrial and commercial uses.

The sands of the Gordon Aquifer may have a hydraulic conductivity similar to that of the McQueen Branch and the Crouch Branch Aquifers. However, the relative thinness of the unit yields lower transmissivity values. Results of tests reported in the literature are difficult to interpret because there was no differentiation between the Gordon Aquifer and the overlying sediments of the lower part of the Upper Three Runs Aquifer. Presumably, most test results come from wells screened predominately in the Gordon Aquifer because of the silty and clayey nature of the sediments making up the lower part of Upper Three Runs Aquifer.

Two constant discharge, multiple-well pumping tests were performed on the Gordon Aquifer at the $H$ Area seepage basins (Albenesius et al. 1990). Estimated transmissivity ranged from 1640 to 2250 $\mathrm{ft}^{2} /$ day (152 to $209 \mathrm{~m}^{2} /$ day) with an average of $2010 \mathrm{ft}^{2} /$ day $\left(187 \mathrm{~m}^{2} /\right.$ day) in Test $\mathrm{I}$, and from 1810 to $2560 \mathrm{ft}^{2} /$ day (168 to $238 \mathrm{~m}^{2} /$ day) with an average of $2270 \mathrm{ft}^{2} /$ day $\left(211 \mathrm{~m}^{2} /\right.$ day) in Test II. Some local leakage through the overlying Gordon Confining Unit was apparent in well HSB-69A. Storage 
coefficient estimates ranged from 0.00022 to 0.00031 for Test $I$, with an average of 0.00027 , and from 0.00020 to 0.00029 with an average of 0.00025 for Test II (excluding HSB-69A well).

The Gordon Aquifer provides water to SRS and to the surrounding rural population. The aquifer is capable of large yields at SRS (tens to hundreds of gallons per minute) and in nearby municipal wells. Siple (1967) reported maximum yields of $660 \mathrm{gpm}\left(2.91 \mathrm{~m}^{3} / \mathrm{min}\right)$ from some SRS wells that probably were pumping the Gordon Aquifer. Some municipal Congaree wells at Barnwell, South Carolina, yield $400 \mathrm{gpm}\left(1.76 \mathrm{~m}^{3} / \mathrm{min}\right)$. The number of users will probably increase as the region develops, but most users who require thousands of gallons per minute will develop wells within the Dublin-Midville Aquifer System. Thus, the total quantity pumped from the Gordon Aquifer will probably increase more slowly than the total quantity pumped from the Dublin-Midville Aquifer System.

\section{Gordon Confining Unit}

The Gordon Confining Unit has been informally termed the "green clay" at the SRS. The average calculated porosity (Beard and Weyl 1973) of 42 sand samples from the Gordon Confining Unit was $34.7 \pm 3.0 \%$, and the geometric mean hydraulic conductivity was $54.2 \mathrm{ft} /$ day $(16.5 \mathrm{~m} /$ day $)$. Porosity ranged from 29.5 to $40.1 \%$, and conductivity ranges from 5.2 to $260 \mathrm{ft} /$ day $(0.30$ to $79.2 \mathrm{~m} /$ day) (Aadland et al. 1994).

Four muddy-sand samples from the Gordon Confining Unit were analyzed for porosity and hydraulic conductivity (Bledsoe et al. 1990). Porosity and hydraulic conductivity measurements have not been made on muds (clays, silty clays, and sandy clays) from the Gordon Confining Unit. Mean porosity of the four muddy-sand samples was $40.0 \pm 1.9 \%$ (Aadland et al. 1994). The geometric mean of the vertical hydraulic conductivity was $4.08 \times 10^{-7} \mathrm{ft} /$ day $\left(1.24 \times 10^{-7} \mathrm{~m} /\right.$ day $)$. The geometric mean of four horizontal hydraulic conductivity meașurements on these muddy sands was $2.88 \times 10^{-3} \mathrm{ft} /$ day $(8.78 \mathrm{x}$ $10^{-4} \mathrm{~m} /$ day) (Aadland et al. 1994).

\section{Upper Three Runs Aquifer}

Porosities and hydraulic conductivities were estimated from sieve analyses for 88 Upper Three Runs Aquifer sands containing less than 25\% mud using the method of Beard and Weyl (1973). The porosity of Upper Three Runs sands averaged 35.3 $\pm 3.0 \%$ and ranged from 27.0 to $40.8 \%$ (Aadland et al. 1994). The calculated porosity values were approximately normally distributed. Calculated conductivity values ranged from 9.6 to $410 \mathrm{ft} /$ day (2.9 to $125 \mathrm{~m} /$ day, Aadland et al. 1994) Almost $60 \%$ of the conductivity values lie between 44 and $175 \mathrm{ft} /$ day (13.4 and $53.3 \mathrm{~m} /$ day). The geometric mean conductivity of 88 sand samples was $85.4 \mathrm{ft} /$ day $(26.0 \mathrm{~m} /$ day). Calculated conductivity values of Upper Three Runs Aquifer sands follow a log-normal distribution, and are slightly skewed toward lower values (Aadland et al. 1994).

Earlier work used sieve analyses performed on samples of materials obtained from the screened zones of the Resource Conservation and Recovery Act (RCRA) monitoring wells in each of three areas: the Mixed Waste Management Facility (MWMF), F-Area Basins, and H-Area Basins in the GSA. The grain-size analyses were used to estimate hydraulic conductivity using the method of Beard and Weyl (1973). The values were compiled and arithmetic means were calculated. The mean of the complete data-set is $123 \mathrm{ft} /$ day $(37.5 \mathrm{~m} /$ day), $\mathrm{n}=20$, the values range from 13 to $479 \mathrm{ft} /$ day (4.0 to $146 \mathrm{~m} /$ day) (Aadland et al. 1994). The method of Beard and Weyl (1973) gives elevated estimates of hydraulic conductivity (e.g., slug test results for the interval range from 0.05 to $45 \mathrm{ft} /$ day $(0.015$ to $13.7 \mathrm{~m} /$ day), and pump tests results range from 0.3 to $3.6 \mathrm{ft} /$ day ( 0.09 to $1.10 \mathrm{~m} /$ day) Aadland et al. 1994). 
Nine samples from the Upper Three Runs Aquifer were analyzed for porosity and hydraulic conductivity by Bledsoe et al. (1990). The mean porosity of the muddy-sand samples was $50.0 \pm 3.4 \%$, and the geometric mean hydraulic conductivity (vertical) was $1.03 \times 10^{-7} \mathrm{ft} /$ day $\left(3.14 \times 10^{-8} \mathrm{~m} /\right.$ day). The geometric mean of five horizontal-conductivity measurements made on these muddy-sand samples was $6.76 \times 10^{-3} \mathrm{ft} /$ day $\left(2.06 \times 10^{-3} \mathrm{~m} /\right.$ day $)$. The average porosity of the four mud samples was $45.0 \pm 8.7 \%$, and geometric mean vertical conductivity was $1.27 \times 10^{-7} \mathrm{ft} /$ day $\left(3.87 \times 10^{-8} \mathrm{~m} /\right.$ day $)$. The geometric mean of three horizontal-conductivity measurements on the same mud samples was $4.71 \times 10^{-2} \mathrm{ft} /$ day $\left(1.43 \times 10^{-2} \mathrm{~m} /\right.$ day) (Aadland et al. 1994).

Tests at SRS indicate an average hydraulic conductivity of $0.43 \mathrm{ft} /$ day $(0.131 \mathrm{~m} /$ day $)$ for the clastic facies of the Upper Three Runs Aquifer, and $0.23 \mathrm{ft} /$ day $(0.070 \mathrm{~m} /$ day) for the calcareous zones observed mostly in the Santee Limestone (Logan and Euler 1989). During drilling operations, drillers noted many instances of drill-rod drops and loss of circulation when penetrating the calcareous zones. Usually, this is an indication of high conductivity. However, subsequent pumping tests indicate that these zones of seemingly high conductivity are not connected. Regionally, the conductivity of the calcareous zones is often very low.

\section{"Upper Aquifer" Zone}

The "upper aquifer" zone of the Upper Three Runs Aquifer consists of all the saturated strata which lie between the water table and the "tan clay" confining zone. This zone has a general downward potential into the underlying aquifer units. The "tan clay" confining zone impedes the movement of water through it; however, it does allow for some recharge to the "lower aquifer" zone. The "upper aquifer" zone consists of silty sand of the Dry Branch Formation which is slightly more permeable than an overlying clayey sand of the Tobacco Road Sand. A pumping test in a sand lens of the Dry Branch Formation indicates a hydraulic conductivity of $0.99 \mathrm{ft} /$ day $(0.302 \mathrm{~m} /$ day $)$. An average value of $0.13 \mathrm{ft} /$ day $(0.0396 \mathrm{~m} / \mathrm{day})$ for the hydraulic conductivity of the clayey sand of the Tobacco Road Sand has been calculated from point-dilution tracer tests at SRS (Christensen and Gordon 1983).

Hydraulic conductivity estimates for the "upper aquifer" zone have been obtained using sieve analyses, slug tests, and pumping tests. Slug tests have been performed on many of the water table wells installed since 1986. The values for 84 slug tests range from 0.05 to $45.4 \mathrm{ft} /$ day $(0.0152$ to 13.8 m/day) (WSRC, 1991, Table 3.5-14a, b, c). The arithmetic means were calculated at each three areas: MWMF, F-Area Basins, and H-Area Basins. The mean data are presented in Table 1-4. The arithmetic mean for the complete data-set ( 84 values) is $5.32 \mathrm{ft} /$ day $(1.62 \mathrm{~m} /$ day).

Two series of single-well pumping tests have been performed on the upper aquifer zone. Parizek and Root (1986) conducted 38 single well pump tests in the vicinity of the GSA. Hydraulic conductivity values calculated from these tests were reported to range from 0.30 to $3.6 \mathrm{ft} /$ day 0.091 to $1.10 \mathrm{~m} /$ day) with a median value of $0.61 \mathrm{ft} /$ day $(0.186 \mathrm{~m} /$ day). A more recent series of tests (Evans and Parizek 1989) produced values much higher than the highest value from the study of Parizek and Root (1986).

Only one large-scale aquifer test has been performed in the "upper aquifer" zone of the Upper Three Runs Aquifer. D'Appolonia (1981) measured a hydraulic conductivity of $13 \mathrm{ft} /$ day (3.96 m/day) northeast of $\mathrm{H}$ Area with storage coefficients ranging from $1.2 \times 10^{-4}$ to $9.3 \times 10^{-3}$. Results of smallscale aquifer tests in the separations areas yield hydraulic conductivity values of 0.1 to $1.0 \mathrm{ft} /$ day ( 0.03 to $0.3 \mathrm{~m} / \mathrm{day}$ ). A $150-\mathrm{ft}$ deep well in Williston, South Carolina (five miles northeast of SRS), yields $200 \mathrm{gal} / \mathrm{min}\left(\left(0.88 \mathrm{~m}^{3} / \mathrm{min}\right)\right.$ from the "upper aquifer" zone of the aquifer. In addition, the (Root 1983) numerical model of a part of the "upper aquifer" zone of the Upper Three Runs Aquifer in the 
GSA indicates a hydraulic conductivity of $6 \mathrm{ft} /$ day $(1.8 \mathrm{~m} /$ day $)$. These estimates indicate a large degree of variability in the hydraulic properties. Hydraulic conductivity estimates used in previous modeling studies of the GSA are 0.8 and $3.6 \mathrm{ft} /$ day $(0.24$ and $1.10 \mathrm{~m} /$ day) (GeoTrans 1988,1989$)$.

"Tan Clay" Confining Zone

The "tan clay" confining zone separates the upper aquifer zone from the lower aquifer zone of the Upper Three Runs Aquifer. This zone is a leaky confining zone. Laboratory analyses of vertical and horizontal conductivity were performed on representative undisturbed samples from the zone. The range of vertical conductivity measurements was from $1.9 \times 10^{-5}$ to $0.12 \mathrm{ft} /$ day $\left(5.79 \times 10^{-6}\right.$ to 0.0366 $\mathrm{m} /$ day) (Bledsoe et al. 1990). The bulk density of some of the samples tested are indicative of silty and sandy sediment.

\section{. "Lower Aquifer" Zone}

The "lower aquifer" zone of the Upper Three Runs Aquifer consists of saturated strata which lie between the "tan clay" confining zone and the Gordon Confining Unit. This zone is poorly confined and is recharged primarily by downward flow from the upper aquifer zone. Hydraulic conductivity estimates for the "lower aquifer" zone have been made using sieve analyses, slug tests, and pumping tests. The range of values from $46 \mathrm{slug}$ tests was fi:om 0.13 to $136.0 \mathrm{ft} /$ day $(0.0396$ to $41.4 \mathrm{~m} /$ day) (Sirrine 1987, 1988a; S\&ME 1988 a, b). The arithmetic means were calculated at each of the three areas: MWMF, F-Area Seepage Basins, and H-Area Seepage Basins. These results are presented in Table 6-7.

Sieve analyses were performed on samples of materials obtained from the lower aquifer zone. The grain-size analyses were used to estimate hydraulic conductivity using the method of Beard and Weyl (1973) (Aadland et al. 1994). The values were compiled and arithmetic means were calculated at each of three areas: MWMF, F-Area Seepage Basins, and H-Area Seepage Basins. The mean of the overall data set is $193 \mathrm{ft} /$ day $(58.8 \mathrm{~m} /$ day), $n=17$. The values range from a 37 to $397 \mathrm{ft} /$ day (11.3 to 121 $\mathrm{m} /$ day).

Parizek and Root (1986) conducted a series of 51 single-well pump tests on wells screened in the "lower aquifer" zone in and around the GSA. Hydraulic conductivity values from these tests ranged from $0.17 \mathrm{ft} /$ day to $2.6 \mathrm{ft} /$ day $(0.052$ to $0.79 \mathrm{~m} /$ day) with a median value of $0.90 \mathrm{ft} /$ day $(0.27 \mathrm{~m} /$ day).

Four values for transmissivity were obtained in the "lower aquifer" zone, in the vicinity of the GSA from long-term tests in which partial penetration corrections were not needed. Three tests in $\mathrm{H}$ Area provided an average transmissivity of $62 \mathrm{ft} 2 /$ day $(5.76 \mathrm{~m} 2 /$ day $)$. Given a thickness of $70 \mathrm{ft}(21.3 \mathrm{~m})$ at this site, the average hydraulic conductivity is $0.88 \mathrm{ft} /$ day. $(0.27 \mathrm{~m} /$ day $)$ The fourth test was performed northeast of $\mathrm{H}$ Area (D'Appolonia 1981) and resulted in a transmissivity value of 88 $\mathrm{ft} 2 /$ day $(8.17 \mathrm{~m} 2 /$ day). Given a thickness of $55 \mathrm{ft}(16.8 \mathrm{~m})$ at this site, the hydraulic conductivity for the "lower aquifer" zone is $1.6 \mathrm{ft} /$ day $(0.49 \mathrm{~m} /$ day $)$. Pump tests such as these integrate the hydraulic characteristics by testing both the sandy facies and the calcareous facies of the "lower aquifer" zone of the Upper Three Runs Aquifer. 
Floridan-Midville Aquifer System

Steed Pond Aquifer

Introduction

The porosities and hydraulic conductivities of 160 Steed Pond Aquifer sands containing less than $25 \%$ mud were estimated from sieve analyses using the method of Beard and Weyl (1973). The porosity of Steed Pond sands averages $34.8 \pm 2.7 \%$ and ranges from 26.3 to $41.0 \%$ (Aadland et al. 1994). The distribution of calculated porosity values appears to be normal and is slightly skewed toward lower values. The calculated hydraulic conductivity values ranged from 5.8 to $900 \mathrm{ft} /$ day (1.77 to $274 \mathrm{~m} /$ day). More than half of the conductivity values fell between 88 and $350 \mathrm{ft} /$ day ( 26.8 and 107 $\mathrm{m} /$ day). The geometric mean conductivity of the samples was $131 \mathrm{ft} /$ day $(39.9 \mathrm{~m} /$ day $)$. Calculated conductivity values of Steed Pond Aquifer sands follow an approximate log-normal distribution, and are skewed toward lower values (Aadland et al. 1994).

Bledsoe et al. (1990) measured the porosity and conductivity of five samples from the Steed Pond Aquifer. The mean porosity of the three muddy-sand samples was $48.7 \pm 5.4 \%$, and the geometric mean of the vertical hydraulic conductivity was $1.57 \times 10^{-6} \mathrm{ft} /$ day $\left(4.78 \times 10^{-7} \mathrm{~m} /\right.$ day $)$. The geometric mean of two horizontal conductivity measurements on the muddy-sand samples was $3.12 \times 10^{-3}$ $\mathrm{ft} /$ day (9.51 $\times 10^{-4} \mathrm{~m} /$ day). The average porosity of two mud samples from the Steed Pond Aquifer was $53.5 \pm 3.5 \%$ and the geometric mean vertical hydraulic conductivity was $1.49 \times 10^{-8} \mathrm{ft} /$ day (4.54 x $10^{-9} \mathrm{~m} /$ day). The geometric mean horizontal hydraulic conductivity of the mud samples was $6.11 \mathrm{x}$ $10^{-4} \mathrm{ft} /$ day $\left(1.86 \times 10^{-4} \mathrm{~m} /\right.$ day $)$.

\section{"M-Area" Aquifer Zone}

Many pump tests, sieve analyses and other studies have been performed to characterize the "MArea" Aquifer Zone in the A/M Area. Hydrogeologic properties of the saturated zone have primarily been evaluated through the performance of aquifer tests. The data derived from well designed, fully penetrating pump tests indicate that the composite saturated hydraulic conductivity of the upper water bearing zones is approximately $3.0 \times 10^{-4}$ to $3.9 \times 10^{-4} \mathrm{ft} /$ day $\left(9.14 \times 10^{-5}\right.$ to $1.18 \times 10^{-5} \mathrm{~m} /$ day $)$. As expected, values obtained at monitoring wells (slug tests that are impacted by short screens and inefficient design) yielded lower values.

Several groundwater flow and transport models have been developed to support the groundwater corrective action program in the A/M Area of SRS (Dupont 1986; Haselow 1991). Calibration of these models is based on matching water levels, as well as data on recharge and streamflow in the model area. Thus, the calibrated models provide an additional means to estimate aquifer parameters; these estimates represent the consolidation of several types of data based on fundamental hydrologic relationships and mathematical algorithms. Table 1-4 lists aquifer parameters resulting from model calibration in the A/M Area (Eddy et al. 1991). The composite horizontal hydraulic conductivity of the upper zones (calculated as the depth weighted mean; Freeze and Cherry 1979) is $4.3 \times 10^{-4} \mathrm{ft} /$ day $\left(1.31 \times 10^{-4} \mathrm{~m} /\right.$ day). This value compares favorably with the pump test results presented above.

Sirrine (1991) calculated a horizontal hydraulic gradient of 0.0035 for the "M-Area" Aquifer Zone using an average hydraulic conductivity value of $5.18 \mathrm{ft} /$ day $(1.58 \mathrm{~m} /$ day $)$ derived from slug test data. Assuming an effective porosity of 0.20 for slightly silty or clayey sands, the average linear flow velocity in "M-Area" Aquifer Zone was estimated to be $0.09 \mathrm{ft} /$ day or $33 \mathrm{ft} / \mathrm{yr}(0.027 \mathrm{~m} /$ day or 10.0 
$\mathrm{m} / \mathrm{yr}$ ). As with their analysis of the other aquifer zones, they concluded that the flow rate could be considerably higher or lower based on the average horizontal hydraulic conductivity estimate used to calculate it.

The vertical flow velocity through the "M-Area" Aquifer Zone was estimated by assuming a vertical hydraulic conductivity that is one order-of-magnitude less than the horizontal and a measured vertical gradient from existing well clusters in A/M Area. The vertical gradient through the "M-Area" Aquifer Zone ranges from 0.01 to 0.17 based on measurements at wells MSB-9, MSB-11, and MSB-18 (middle of $A / M$ Area). Using the same porosity of 0.20 , an average vertical hydraulic conductivity of $0.52 \mathrm{ft} /$ day $(0.158 \mathrm{~m} /$ day), and assuming an average vertical gradient of 0.09 , the average linear vertical flow velocity in the zone is estimated as $0.25 \mathrm{ft} /$ day or $90 \mathrm{ft} / \mathrm{yr}(0.076 \mathrm{~m} /$ day or $27.8 \mathrm{~m} / \mathrm{yr})$. This indicates that the potential for downward flow or recharge within the "M-Area-Aquifer Zone is greater than the potential for lateral flow. Based on the distance to discharge areas and on the topography of $\mathrm{A} / \mathrm{M}$ Area, this is a reasonable conclusion.

"Lost Lake" Aquifer Zone

Geraghty and Miller (1986) conducted aquifer tests using monitoring wells screened in the "Lost Lake" Aquifer Zone. The transmissivity values vary considerably, from 36,000 to $720,000 \mathrm{ft}^{2} /$ day (3300 to $67,000 \mathrm{~m}^{2} /$ day). Reasonable average values for the transmissivity, storage coefficient, and leakance are $112,000 \mathrm{ft}^{2} /$ day $\left(10,400 \mathrm{~m}^{2} /\right.$ day), $7.6 \times 10^{-4}$, and $0.0751 /$ day, respectively. Hydraulic conductivity estimates, based on slug tests, range from 1.56 to $77.7 \mathrm{ft} /$ day $(0.475$ to $23.7 \mathrm{~m} /$ day $)$ and average $14.2 \mathrm{ft} /$ day ( $4.33 \mathrm{~m} /$ day) (Sirrine 1991). Assuming a porosity of 0.30 as typical for coarse sand and a hydraulic gradient of 0.003 , the average linear groundwater flow velocity in the "Lost Lake" Aquifer Zone is estimated to be $0.14 \mathrm{ft} /$ day or $51 \mathrm{ft} / \mathrm{yr}(0.0427 \mathrm{~m} /$ day or $15.6 \mathrm{~m} / \mathrm{yr})$. Because the range of hydraulic conductivity estimates is relatively broad, flow rate estimates could be much higher or lower than this estimate which is based on an average hydraulic conductivity and gradient.

A series of aquifer tests were conducted in the A/M Area between 1990 and 1994 (Hiergesell 1993, Hiergesell 1994, Hiergesell et al. 1994). These tests focused on the Lost Lake Aquifer to obtain information on the hydraulic characteristics of that formation. In addition, they were designed to obtain indirect information regarding the hydraulic conductivity of adjacent confining units and the degree of interconnection of the Lost Lake Aquifer with aquifer units above and below. Field testing was conducted in 6-inch wells that were installed as part of the recovery well network in the $A / M$ Area for remediating the TCE plume.

The first test was conducted at RWM-16, located in the southern portion of the A/M Area (Hiergesell 1993). Transmissivity values ranged from $5.8 \times 10^{-2}$ to $9.5 \times 10^{-2} \mathrm{~m}^{2} / \mathrm{min}$ ( 0.62 to $\left.1.0 \mathrm{ft}^{2} / \mathrm{min}\right)$. Storativity values ranged from $4.5 \times 10^{-4}$ to $7.3 \times 10^{-4}$. The best fit results were obtained using the Hantush-Jacob method (Hantush and Jacob 1955) indicating that significant quantities of water leak into the Lost Lake Aquifer during pumping. The $\mathrm{r} / \mathrm{B}$ leakage parameter values ranged from $4.6 \times 10^{-}$ 2 to $8.2 \times 10^{-2}$. Vertical hydraulic conductivity values for the overlying clay were calculated from these data by assuming all the leakage was coming from the overlying unit. They ranged form $5.6 \mathrm{x}$ $10^{-7}$ to $3.2 \times 10^{-6} \mathrm{~cm} / \mathrm{sec}$. Leakance values range from $3.1 \times 10^{-9}$ to $2.1 \times 10^{-8} \mathrm{sec}^{-1}$ assuming a range of aquitard thickness of 150 to $180 \mathrm{~cm}$ (5 to 6 feet).

Another Lost Lake Aquifer test was conducted at R.WM-12, located in the northern portion of the A/M Area (Hiergesell 1994). In this part of the A/M Area the Lost Lake Aquifer Unit is divided into upper and lower sub-zones by a competent clay layer. RWM-12 has two screen sections, one completed in the upper sub-zone and the other in the lower sub-zone. No change in water levels were 
observed in a well screened in the upper sub-zone. This was attributed to formation damage caused by the drilling process. Estimates of transmissivity for the lower Lost Lake aquifer zone ranged from a high of $0.161 \mathrm{~m}^{2} / \mathrm{min}\left(1.73 \mathrm{ft}^{2} / \mathrm{min}\right)$ to a low of $0.059 \mathrm{~m}^{2} / \mathrm{min}\left(0.636 \mathrm{ft}^{2} / \mathrm{min}\right)$. Storativity ranged from $1.68 \times 10^{-4}$ to $7.39 \times 10^{-4}$. At the three wells for which Hantush-Jacob (Hantush and Jacob 1955 ) analyses were conducted, estimates of $\mathrm{K}_{\mathrm{V}}$ ranged from $4.01 \times 10^{-6}$ to $8.79 \times 10^{-6} \mathrm{~cm} / \mathrm{sec}$. Sieve analyses conducted on core material taken from RWM-12 allowed calculation of transmissivity the upper and lower Lost Lake Aquifer zones by a non-hydraulic method. Results of this analysis gave results that compared closely with hydraulic estimates of transmissivity in the Lower Lost Lake Aquifer zone.

Well tests were conducted on 5 newly installed recovery wells in A/M Area in 1994 to assess the pumping capacity of each and to obtain estimates of hydraulic parameters for the formations within which each well is finished (Hiergesell, et al. 1994). The new recovery wells are RWM-13B, RWM13C, RWM-14B, RWM-14C, and RWM-15B, all of which are located in the northern section of the A/M Area. Transmissivity estimates ranged from 0.111 to $0.698 \mathrm{~m}^{2} / \mathrm{min}\left(1.19\right.$ to $7.51 \mathrm{ft}^{2} /$ day $)$ for the Lower Lost Lake Aquifer, and storativity ranged from $1.96 \times 10^{-4}$ to $3.11 \times 10^{-5}$. For the Upper Lost Lake Aquifer, transmissivity ranged from 0.030 to $0.146 \mathrm{~m} / \mathrm{min}\left(0.32\right.$ to $1.57 \mathrm{ft}^{2} /$ day $)$, and storativity values ranged from $3.86 \times 10^{-4}$ to $1.08 \times 10^{-4}$.

Crouch Branch Confining Unit

\section{Introduction}

Pumping water from production wells screened in the Crouch Branch Aquifer during the aquifer tests conducted by Geraghty and Miller (1986) influenced the water levels in monitoring wells screened in the overlying Steed Pond Aquifer. It was beyond the scope of that study, however, to quantify, the degree of hydraulic communication between the aquifers. Geraghty and Miller (1983) performed a study specifically designed to assess leakance across the Crouch Branch Confining Unit. They determined that leakance of the confining unit ranged from $8.15 \times 10^{-3} /$ day to $2.43 \times 10^{-2} /$ day. The Geraghty and Miller (1986) analysis corroborates the lithostratigraphic interpretation presented in Aadland et al. (1994) that the Crouch Branch Confining Unit is breached in the A/M Area.

The regional baseline study conducted by Bledsoe et al. (1990) summarized laboratory test results conducted on clay samples taken from the Crouch Branch Confining Unit in the vicinity of A/M Area. Hydraulic conductivity values were calculated. Vertical hydraulic conductivity varies from $2.50 \times 10^{-}$ 6 to $7.91 \times 10^{-8} \mathrm{~cm} / \mathrm{sec}$, averaging $7.33 \times 10^{-7} \mathrm{~cm} / \mathrm{sec}$. Horizontal hydraulic conductivity varies from $1.10 \times 10^{-5}$ to $9.54 \times 10^{-8} \mathrm{~cm} / \mathrm{sec}$, averaging $2.65 \times 10^{-6} \mathrm{~cm} / \mathrm{sec}$.

Simulated regional leakage coefficients from Aucott (1988) for the Crouch Branch Confining Unit range from $10^{-4} /$ day to $10^{-8} /$ day. The leakage coefficients range from about $10^{-4} /$ day to $10^{-6} /$ day over most of the SRS, including both Crouch Branch and the Meyers Branch confining system. The vertical conductivity estimate used in the GeoTrans (1988) modeling studies of the GSA was $3 \times 10^{-4}$ $\mathrm{ft} /$ day $\left(9.1 \times 10^{-5} \mathrm{~m} /\right.$ day). Assuming a thickness of $30 \mathrm{ft}(9.1 \mathrm{~m})$, the leakage coefficient would be $1 \times$ $10^{-5} /$ day. This leakage coefficient value falls within the simulated leakage coefficient range used by Aucott (1988).

"Lower Clay" Confining Zone 
An average vertical hydraulic conductivity of $5.4 \times 10^{-4} \mathrm{ft} /$ day $\left(1.65 \times 10^{-4} \mathrm{~m} /\right.$ day $)$ has been reported for the "lower clay" confining zone from laboratory analyses of undisturbed samples (Bledsoe 1988). Across the A/M Area, the unit thickness ranges from 2 to $50 \mathrm{ft}(0.61$ to $15.2 \mathrm{~m})$. The hydraulic head difference across the unit ranges from 12 to $28 \mathrm{ft}(3.6$ to $8.5 \mathrm{~m}$ ) in the $\mathrm{A} / \mathrm{M}$ Area (Bledsoe 1988), and averages $20 \mathrm{ft}(6.1 \mathrm{~m})$. Dividing the average head difference by the average thickness of $25 \mathrm{ft}(7.6 \mathrm{~m})$ yields a vertical gradient of 0.8 . Assuming an effective porosity of 0.12 for silty clay (Fetter 1988), the average linear vertical flow velocity estimated for the "lower clay" confining zone is $3.6 \times 10^{-3} \mathrm{ft} /$ day or $1.3 \mathrm{ft} / \mathrm{yr}\left(1.1 \times 10^{-3} \mathrm{~m} /\right.$ day or $\left.0.40 \mathrm{~m} / \mathrm{yr}\right)$.

"Middle Sand" Aquifer Zone

Geraghty and Miller (1986) conducted aquifer tests using wells screened in the "middle sand" aquifer zone in A/M Area. In general, the match between the data and the type curves is poor. By far, the best curve match was obtained using well pair RWM-10 and MSB-11A, which resulted in estimates of transmissivity of $78,000 \mathrm{ft}^{2} /$ day $\left(7200 \mathrm{~m}^{2} /\right.$ day), a storage coefficient of $2.0 \times 10^{-4}$, and a leakance of 0.14 /day.

\section{"Upper Clay" Confining Zone}

The thickness of "upper clay" confining zone varies from 0 to $15 \mathrm{ft}(0$ to $4.6 \mathrm{~m})$ in A/M Area. The average vertical hydraulic conductivity based on laboratory analyses of undisturbed samples is $9.64 \mathrm{x}$ $10^{-3} \mathrm{ft} /$ day $\left(2.94 \times 10^{-3} \mathrm{~m} /\right.$ day). The average vertical gradient across the zone is 0.15 based on measured heads at $\mathrm{A} / \mathrm{M}$ Area.

\subsection{Confining Systems of the Southeastern Coastal Plain}

\section{Appleton Confining System}

Only three sand samples from the Appleton confining system in wells C-5 and C-10 have been analyzed for grain size. The sands are texturally immature and poorly and very poorly sorted (Aadland et al. 1994). The sands are positively skewed with an excess of fine-grained mud, and are fine- and strongly-fine skewed. Total porosity and hydraulic conductivity were calculated for one sand sample using the method of Beard and Weyl (1973). The resulting total porosity was $35 \%$, and the hydraulic conductivity was $190 \mathrm{ft} /$ day (Aadland et al. 1994).

Marine (1975) reported vertical hydraulic conductivity values for the saprolitic material in the Appleton confining system from two wells to be $1.0 \times 10^{-4}$ and $5.0 \times 10^{-3} \mathrm{ft} /$ day $\left(3.0 \times 10^{-5}\right.$ and $1.5 \mathrm{x}$ $10^{-3} \mathrm{~m} /$ day) and gives the porosity as $38 \%$. For the upper part of the confining system, the reported vertical hydraulic conductivities averaged $2.0 \times 10^{-4} \mathrm{ft} /$ day $\left(6.1 \times 10^{-5} \mathrm{~m} /\right.$ day $)$, and the total porosity averaged $30 \%$.

\section{Allendale Confining System.}

The Allendale confining system separates the Midville Aquifer System from the overlying Dublin Aquifer System regionally. It separates the McQueen Branch and Crouch Branch Aquifers at SRS in the areas from Upper Three Runs Creek towards the southeast. Few hydrogeologic data are available for the Allendale confining system. Calibrated leakage coefficient values range from about $2 \times 10^{-9} /$ day to $5 \times 10^{-4} /$ day in the Allendale (Aucott 1988). Assuming an average thickness of the confining beds of $100 \mathrm{ft}$, vertical hydraulic conductivity values range from about $2 \times 10^{-7}$ to $5 \times 10^{-2}$ 
$\mathrm{ft} /$ day $\left(6.1 \times 10^{-8}\right.$ to $1.5 \times 10^{-2} \mathrm{~m} /$ day). In general, the leakage coefficients are greatest near the updip limit of the unit, where the confining beds typically consist of coarser sediments and are thinnest. Leakage coefficients are lower toward the coast, where the unit has undergone a facies change to finer sediments. For example, near Charleston, South Carolina, leakance coefficients calculated for the Allendale confining system are in the range of $2 \times 10^{-9} /$ day to $1 \times 10^{-8} / \mathrm{day}$. There is, however, little data available to provide quantitative verification for these values (Aucott 1988).

Bledsoe et al. (1990) analyzed two sandy-mud samples from the Allendale confining system for porosity and conductivity. The mean porosity was $39.5 \%$, and the geometric mean vertical conductivity was $2.2 \times 10^{-7} \mathrm{ft} /$ day $\left(6.7 \times 10^{-8} \mathrm{~m} /\right.$ day); horizontal conductivity was $1.09 \times 10^{-4} \mathrm{ft} /$ day $\left(3.32 \times 10^{-5} \mathrm{~m} /\right.$ day $)$.

\section{Meyers Branch Confining System}

The Meyers Branch confining system consists of the clays, silts, and poorly-sorted-muddy sands of the Ellenton Formation; the sands and interbedded-silty clays and clays of the Williamsburg Formation; and the lignitic clays and interbedded sands at the top of the Peedee Formation.

The porosity of 57 Meyers Branch confining system sands containing less than $25 \%$ mud, calculated from median grain size (Trask 1930) and sorting (Beard and Weyl 1973), averages $34.0 \pm 2.4 \%$ and ranges from 28.8 to $39.5 \%$ (Aadland et al. 1994). Calculated conductivity values (Beard and Weyl 1973) of these sands range from 12.3 to $676 \mathrm{ft} /$ day (3.75 to $206 \mathrm{~m} /$ day) (Aadland et al. 1994). The geometric mean conductivity of the 57 sand samples was $115 \mathrm{ft} /$ day.

Twenty-two samples from the Meyers Branch confining system were analyzed for porosity and conductivity (Bledsoe et al. 1990). Mean porosity of the 16 muddy-sand samples is $42.6 \pm 2.5 \%$; the geometric mean hydraulic conductivity (vertical) of 15 of the samples was $1.15 \times 10^{-8} \mathrm{ft} /$ day $(3.51 \times$ $10^{-9} \mathrm{~m} /$ day). The geometric mean of 13 horizontal conductivity measurements on these muds was $6.68 \times 10^{-4} \mathrm{ft} /$ day $\left(2.03 \times 10^{-4} \mathrm{~m} /\right.$ day $)$. The average porosity of six muddy-sand samples from the Meyers Branch confining system is $41.7 \pm 7.9 \%$; the geometric mean vertical hydraulic conductivity was $1.24 \times 10^{-7} \mathrm{ft} /$ day $\left(3.78 \times 10^{-8} \mathrm{~m} /\right.$ day $)$. The geometric mean of 5 horizontal conductivity measurements on the same muddy-sand samples is $1.31 \times 10^{-2} \mathrm{ft} /$ day $\left(3.99 \times 10^{-3} \mathrm{~m} /\right.$ day $)$.

Calibrated leakage coefficient values for the Meyers Branch confining system range from about $2 \mathrm{x}$ $10^{-9} /$ day to $5 \times 10^{-4} /$ day (Aucott 1988). Assuming an average thickness of the confining beds of $100 \mathrm{ft}$, vertical hydraulic conductivity values range from about $2 \times 10^{-7}$ to $5 \times 10^{-2} \mathrm{ft} /$ day $\left(6.1 \times 10^{-8}\right.$ to $1.5 \mathrm{x}$ $10^{-2} \mathrm{~m} /$ day). In general, the leakage coefficient values are greatest near the up-dip limit of the system, where the confining beds typically consist of coarser sediments and are thinnest. Leakage coefficients are lower toward the coast, where the sediments in the system have undergone a facies change to finer sediments. For example, near Charleston South Carolina, leakance values for all confining units are within the $2 \times 10^{-9} /$ day to $1 \times 10^{-8} /$ day range. There is, however, little data available to provide quantitative verification for these values (Aucott 1988).

Three hydraulic conductivity measurements on clays from the Meyers Branch confining system at SRS have been reported. Bledsoe (1987) recorded a vertical hydraulic conductivity $(\mathrm{K})$ of $4.0 \times 10^{-5}$ $\mathrm{ft} /$ day $\left(1.2 \times 10^{-5} \mathrm{~m} /\right.$ day) for a clay sample from well P-19. (Bledsoe 1987) also reported vertical hydraulic conductivities of $1.4 \times 10^{-4}$ and $1.02 \times 10^{-3} \mathrm{ft} /$ day $\left(4.3 \times 10^{-4}\right.$ and $3.1 \times 10^{-4} \mathrm{~m} /$ day) for two 
clays from well P-22 (see Figure 3-12). These data are consistent with the interpretation that the clays of the Meyers Branch confining system represent aquitards.

The Meyers Branch confining system was penetrated in 15 borings in the General Separations Area and attains a thickness of more than $100 \mathrm{ft}$ in this part of the SRS. Vertical hydraulic conductivity values of the clay and silt beds in the system were calculated. They ranged from $7.7 \times 10^{-5}$ to $2.9 \mathrm{x}$ $10^{-4} \mathrm{ft} /$ day $\left(2.3 \times 10^{-5}\right.$ to $8.8 \times 10^{-5} \mathrm{~m} /$ day). Horizontal hydraulic conductivity ranges from $1.0 \times 10^{-4}$ to $1.1 \times 10^{-4} \mathrm{ft} /$ day $\left(3.1 \times 10^{-5}\right.$ to $3.3 \times 10^{-5} \mathrm{~m} /$ day) (Bledsoe et al. 1990). The consistency of the low conductivity values (vertical and horizontal) indicate the confining capabilities of this system.

\subsubsection{Unsaturated (Vadose) Zone Groundwater Flow}

\subsection{Introduction}

The water table is a major hydrogeologic feature in the subsurface. Below the water table, the pores between the sediment grains are completely filled with water, i.e., the sediments are saturated with water or simply "saturated," with the reference to water being implied. Above the water table, the pores are filled with a variable mixture of air and water, i.e., the sediments are unsaturated. The region above the water table is thus called the unsaturated zone. It is also called the vadose zone.

Water in the vadose zone generally exists at a pressure which is less than atmospheric pressure. This occurs because of the attraction which exists between water and the surfaces of sediment grains. This attraction creates a capillary force which acts to hold water in place in the porous sediments. The smaller the pores (i.e., the finer the grains) the stronger is this capillary force. Thus fine-grain sediments like clays will generally tend to retain more water under unsaturated conditions than will coarser-grained sediments, that is finer-grained sediments generally are more saturated than coarser sediments, which drain more quickly.

The patterns of water flow in unsaturated or vadose zone sediments can be quite different from what one would expect in saturated sediments because of the capillary force and water saturation effects. This occurs because permeability is directly related to water saturation in unsaturated or vadose zone sediments. Water flow rates can be faster in fine-grained sediments relative to coarse-grained sediments because of this phenomenon. This is the opposite behavior of what occurs below the water table where water flow occurs more readily in coarse-grained layers.

\subsection{Recharge}

The main source of recharge to the water table aquifer is rainfall (and occasionally snow melt) which seep into the ground through the vadose zone. Annual rainfall at SRS averages approximately 122 $\mathrm{cm}$ (48 in., Hubbard 1986). There is a seasonal pattern to the rainfall with January through March receiving higher amounts of rain and October through December receiving lower rainfall. Hubbard (1986) also provides an estimate of the annual water budget of precipitation based on lysimeter studies performed in the General Separations Area. In bare soil and grass covered areas, Hubbard estimated that the $122 \mathrm{~cm}$ (48 in.) of precipitation can be partitioned as $40.7 \mathrm{~cm}$ (16 in.) to subsurface recharge, $5.1 \mathrm{~cm}$ (2 in.) to runoff to local streams, and $76.2 \mathrm{~cm}$ (30 in.) to evapotranspiration. In forested areas, Hubbard estimated that evapotranspiration increases to $102 \mathrm{~cm}$ (40 in.) and recharge decreases to approximately $15.2 \mathrm{~cm}(6 \mathrm{in}$.) The large increase in evapotranspiration for forested areas can be attributed to the large transpiration potential of pines, such as loblolly. 


\subsection{Direction of Groundwater Flow in the Vadose Zone}

The direction of groundwater flow in the vadose zone is predominantly downward. However, lenses of silt and clay may cause significant lateral spread in some areas. The extent of lateral spreading can be estimated by examining tritiated water in the unsaturated zone; one should use caution in using other contaminant data due to the chemical interactions between the contaminant and the soil, which effect how different contaminants move with the unsaturated flow, and the lateral spread that can occur in multi-component flow such as with solvents.

As a result of the complex, layered hydrogeology of the site, perched water does exist in several areas. Therefore, one must be careful interpreting information from water table wells by observing whether hydraulic head is consistent with the water table map for SRS (Figure 1-28). In the absence of perched water, the vadose zone thickness ranges from approximately $40 \mathrm{~m}(130 \mathrm{ft})$ in the northern-most portion of the site (A/M Area) to $0 \mathrm{~m}$ where the water table intersects wetlands, streams, or creeks.

\subsubsection{Groundwater Quality and Chemistry}

\subsubsection{Introduction}

The quality of groundwater in the principal hydrologic systems beneath the Savannah River Site (SRS) depends on both the source of the water and the inorganic and biochemical reactions that take place along the flow path of the water. It is strongly influenced by the chemical composition and mineralogy of the enclosing geologic materials. Early investigations of the hydrogeology at the site, such as Siple (1967), established the following three geologic and hydrogeologic systems on the site:

- crystalline basement rocks composed of metamorphic and intrusive igneous rocks

- well-indurated Triassic-aged sediments in the Dunbarton Basin

- the overlapping, weakly consolidated Cretaceous to Recent coastal plain sediments

The three systems differ significantly in the quality and chemical composition of their indigenous waters.

The crystalline basement rocks have very low permeabilities. Water is stored primarily in the fractures and joints in the rocks. The most reliable water quality data came from deep rock borings to the basement near the center of the site during the Bedrock Waste Storage Exploration Program (Marine 1976). The data indicate that the groundwater in the crystalline basement are high in total dissolved solids (TDS), ranging from 5000 to $6000 \mathrm{mg} / \mathrm{L}$, and are high in sodium, sulfate, and chloride.

The total dissolved solids concentration in the Triassic-aged rocks is about 12,000 to $18,000 \mathrm{mg} / \mathrm{L}$, about two to three times that of the crystalline rocks. Two test wells drilled into the Triassic rocks showed that these waters are geopressured and that the hydraulic heads of the waters are above land surface and above the head in the overlying coastal plain aquifer. The origin of the overpressuring is uncertain but has been ascribed to osmotic pressure across the confining units above the Triassic rocks (Marine 1974).

Both the crystalline basement rocks and the Triassic rocks are overlain by varying thicknesses of weathering residue containing degraded minerals and clays. Overlying these old soils is a depositional blanket of indurated, poorly-sorted, clayey sediments of the Cape Fear Formation 
(Bledsoe 1988). This unit and the residual soils comprise the Appleton Confining System, which hydraulically separates and isolates the younger sedimentary materials from the Triassic sediments and the crystalline basement rocks.

\subsubsection{Groundwater Quality in the Atlantic Coastal Plain}

Introduction

The quality of the groundwater in the coastal plain sediments at SRS and the surrounding areas is generally suitable for most domestic and industrial purposes. The waters are dilute-the TDSs range from less than $10 \mathrm{mg} / \mathrm{L}$ to about $150-200 \mathrm{mg} / \mathrm{L}$. The $\mathrm{pH}$ values range from as low as 4.9 to a maximum value of 7.7 (where groundwater is in contact with limestone), and the average $\mathrm{pH}$ is about 6.0. Many SRS groundwaters are corrosive to metal surfaces because of the composition of the waters and the frequently low $\mathrm{pH}$ values. High dissolved iron concentration in some units may also be of concern. A degassification/filtration process is used onsite to raise the $\mathrm{pH}$ and remove iron in domestic water supplies where necessary.

Most of the shallow groundwater is derived from local, recent precipitation as indicated by the concentrations of tritium in the water. At SRS, tritium in local precipitation has been in excess of the normal background levels in the northern hemisphese. The majority of tritium released from the site has been to the atmosphere, amounting to more than $2.4 \times 10^{7} \mathrm{Ci}$ since the beginning of plant operation in 1954 (Murphy et al. 1990). Washout from the atmosphere during periods of precipitation have elevated the concentration of rainfall tritium to where pre- and post-1954 rainfall derived water can be clearly distinguished in groundwater (Strom and Kaback 1992).

The ionic composition of the groundwater also clearly reflects the meteoric origin of the water. The composition of rainwater is not monitored at SRS; however, data from several nearby monitoring sites are available (Strom and Kaback 1992). The precipitation has approximately the same sodiumto-chloride ratio as sea water, a principal source of atmospheric salts, but higher values for sulfate and calcium. Both calcium and sulfate are commonly incorporated as atmospheric salts during the passage of an air mass over land areas. Chloride generally behaves as a conservative constituent in water transport, and it can frequently be used as a txacer of both the movement of water masses and the chemical evolution of the groundwater. Sodium-to-chloride ratios of SRS groundwaters are generally similar to that of seawater. Some analyses show excess sodium relative to chloride. This probably results from silicate dissolution or cation exchange processes (Strom and Kaback 1992)

\section{Hydrochemical Facies}

Within the Coastal Plain sediments, the groundwaters, though very dilute, show significant changes in the levels of dissolved oxygen and the redox potential of the water, dissolved trace constituents, and in the major cations and anions present. These changes in the diagnostic chemical characteristics of the groundwater solutions [i.e., the changes in hydrochemical facies (Back 1966)] represent the cumulative effects of reactions between the influent waters and the materials that comprise the sediments along groundwater flow paths. The most notable changes in the chemical characteristics of SRS groundwater are the changes in the major cation and anion compositions. These changes are illustrated on trilinear or "Piper" diagrams (Figures 1-28 through 1-30). On these diagrams, the major cation composition is plotted on the lower left trilinear diagram and the major anion composition on the trilinear diagram on the lower right. By extending lines from the composition points on the trilinear diagrams parallel to the external edges, a common intersection is found and plotted as a circle on the diamond-shaped grid. The diameter of the circle at the intersections is proportional to the concentration of TDS. A good discussion of the "Piper" diagram 
and comparisons to other means of illustrating groundwater chemical data can be found in Hem (1970).

In Figure 1-28, analyses of water samples from the Floridan-Midville Aquifer System in the northern part of SRS showed no dominant cations or anions. However, in Figure 1-29, analyses of water samples indicated that calcium is the dominant cation and bicarbonate the dominant anion for most samples from the Floridan Aquifer System at SRS. (There were exceptions in a few samples from the central portion of the site.) Analyses of water samples from the Dublin-Midville Aquifer System showed a consistent increase of bicarbonate relative to other anions (Figure 1-30). The cation composition is less consistent and there is evidence of cation exchange processes in down-dip sections (Strom and Kaback 1992).

\section{Floridan-Midville Aquifer System}

On the northern edge of the site where there is a single aquifer system, the waters have very low TDSs concentrations $(<20 \mathrm{mg} / \mathrm{L}$ ), and they contain high concentrations of dissolved oxygen. The waters are acidic, with $\mathrm{pH}$ values less than 6.0, and are of mixed water types (i.e., there are no predominant cations or anions in the water) (Figure 1-28). The confining units that separate the aquifers are of only local extent, and the hydraulic gradient is downward from the Tertiary formations into the underlying Cretaceous formations over much of this portion of the site. The Cretaceous aquifers receive recharge from Tertiary units where the confining units are thin or absent.

\section{Floridan Aquifer System}

In the southeastern region of the site, where there are two or more aquifer systems, the waters become geochemically distinctive as a result of biogeochemical and geochemical reactions between the water and the sediments and buried organic materials. The waters in the Floridan Aquifer System have evolved to predominantly calcium-bicarbonate waters (Figure 1-29). 


\section{GROUNDWATER PROTECTION}

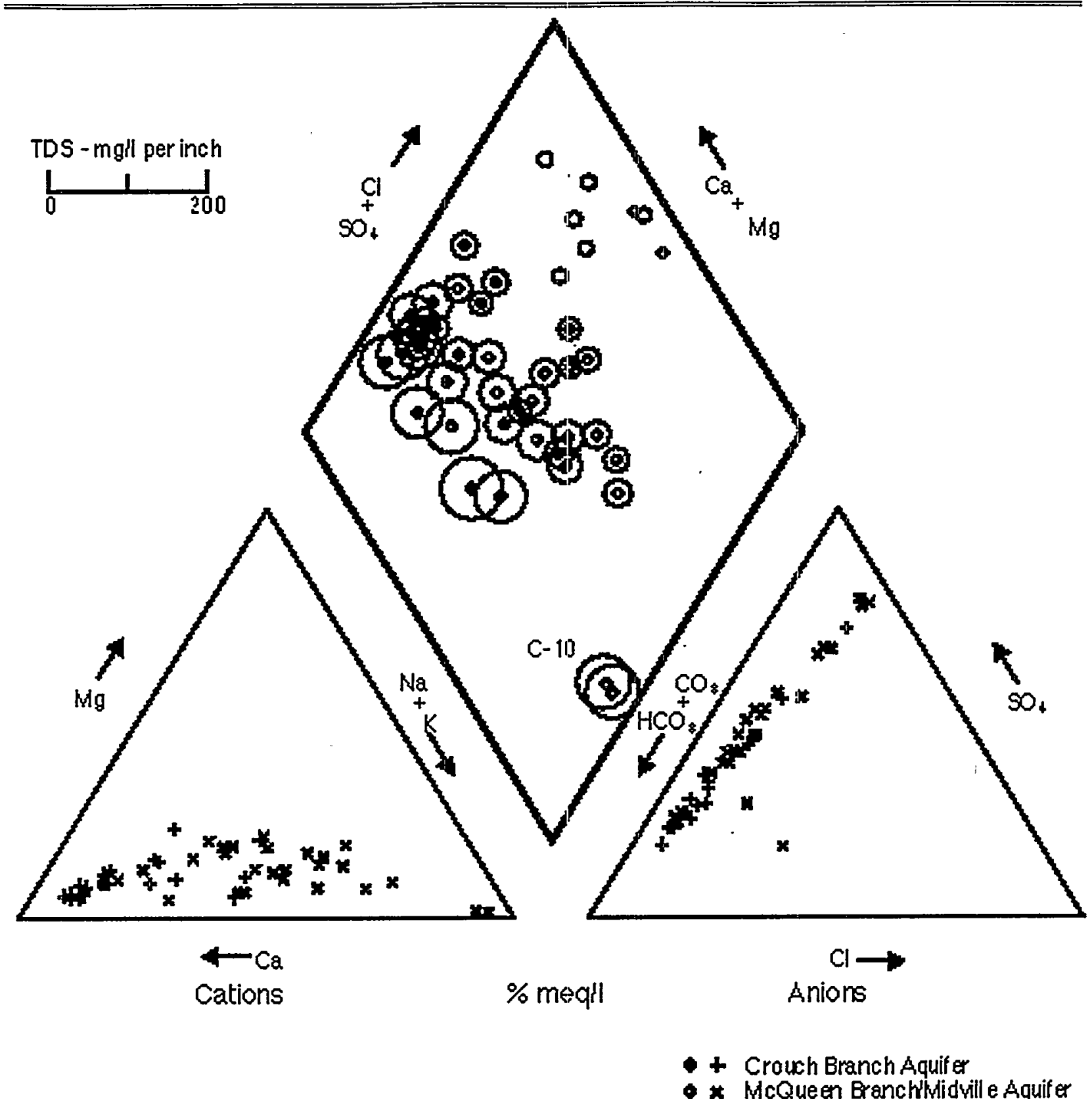

$94 \times 00187.14 . A \mathrm{~L}$

Figure 1-28. Piper diagram of water samples from the Dublin-Midville Aquifer System at the Savannah River Site (Source: Strom and Kaback 1992) 


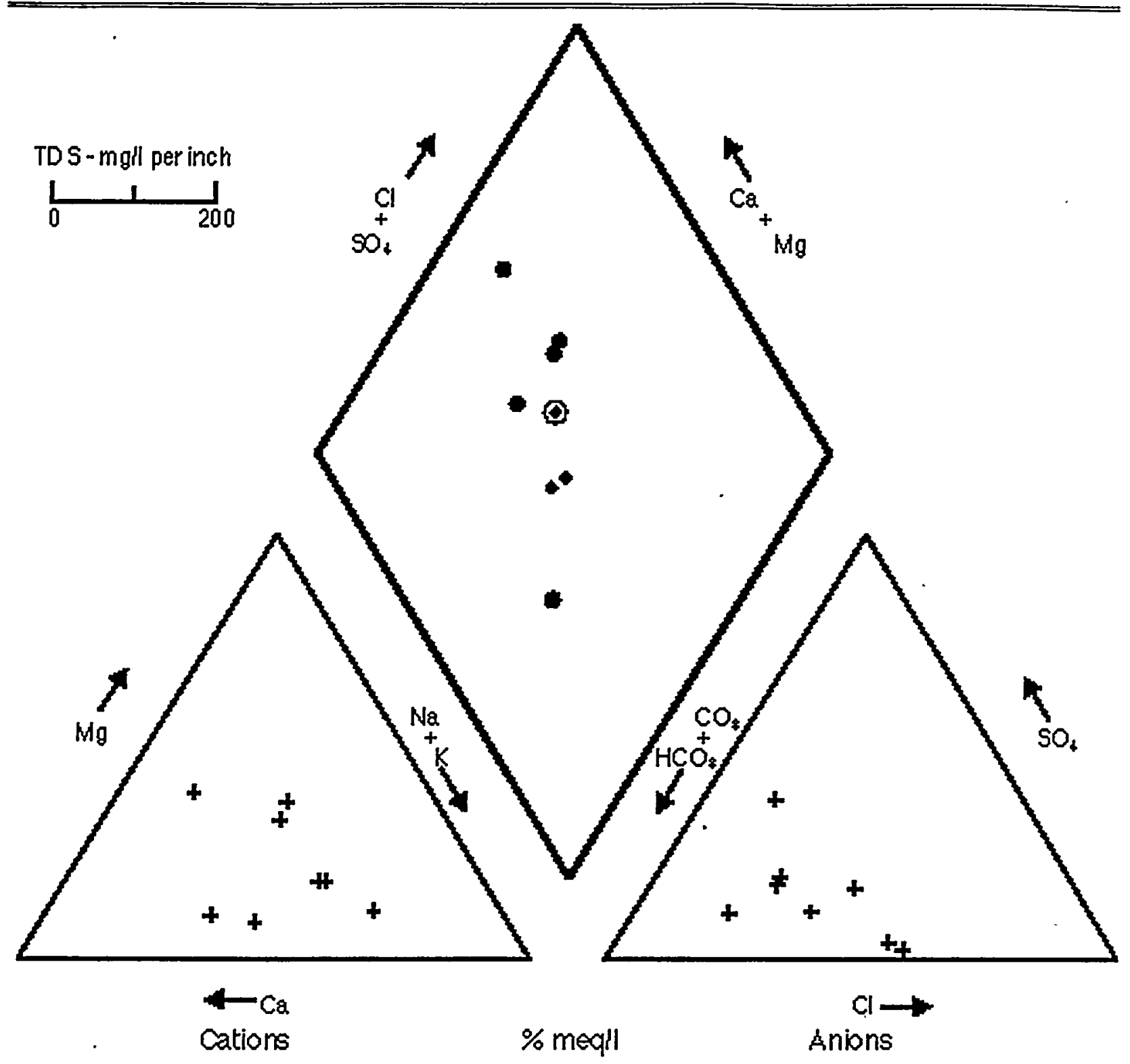

$94 \times 00183.13 . A L$

Figure 1-29. Piper diagram or water samples from the Floridan Aquifer System at the Savannah River Site (Source: Strom and Kaback 1992) 


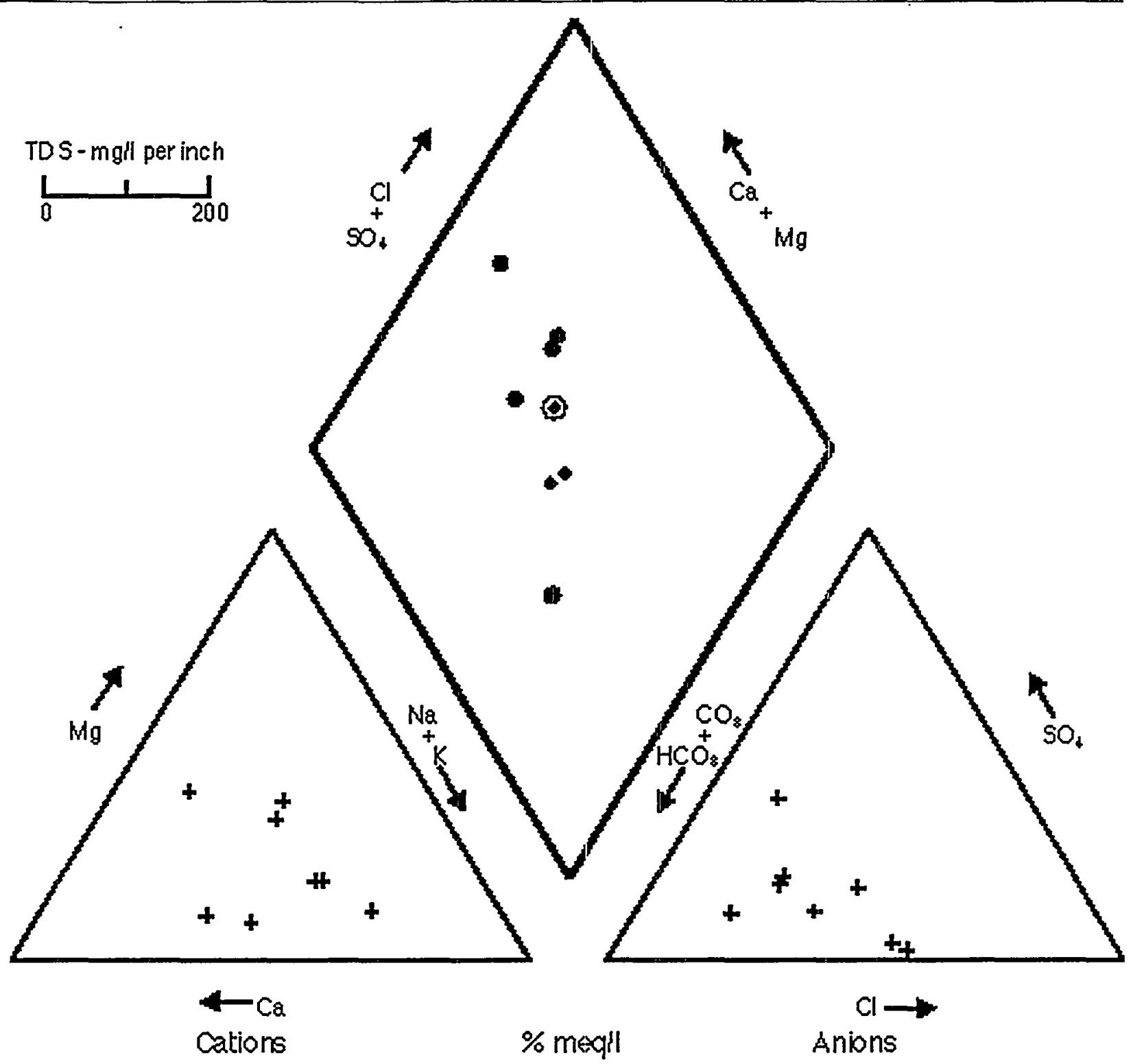

$94 \times 00187.13 . A \mathrm{~L}$

Figure 1-30. Piper diagram of water samples from the Floridan-Midville Aquifer System in the northern part of the Savannah River Site (Source: Strom and Kaback 1992)

The samples from monitoring wells screened in the Tertiary section near the center of the site are exceptions, for example, well FC2E in the P-28 well location and wells P-19C and P-19B . At the P-19 well site, which is located close to the Pen Branch fault, samples from wells in the Upper Three Runs Aquifer and the Gordon Aquifer are low in TDS and show no evidence of having had opportunity to react with carbonates. Limestones, marls, and clay units are conspicuously absent from the Tertiary section at this locality (Bledsoe 1986), and high vertical permeabilities would not be unexpected. 


\section{Dublin-Midville Aquifer System}

The Cretaceous aquifers south of Upper Three Runs that comprise the Dublin-Midville Aquifer System have a somewhat more complex chemistry. Examination of the Piper diagram for these units (Figure 1-30) shows a marked evolution from sulfate-rich waters at low TDS concentrations toward bicarbonate-rich waters at higher TDS concentrations. The evolution toward calcium-rich waters is not as pronounced as in the Tertiary units. Alkalies $(\mathrm{Na}+\mathrm{K})$ are major contributors to the cation compositions, and the waters would be classified as mixed water types or $\mathrm{Na}+\mathrm{K}-\mathrm{HCO} 3$ waters by 'Back's classification system (Back 1966). The reaction pathways toward these compositions are complex and not well understood at present.

The calcium in these waters may be derived from several sources including dissolution of gypsum from confining beds such as the Ellenton Formation, the dissolution of calcite or calcium plagioclase or, possibly, displacement of calcium by potassium in cation exchange reactions. The alkalies in the Cretaceous aquifer waters are primarily derived from the breakdown of silicate minerals including feldspars, mica, and various clay minerals (e.g., illite).

There is no consistent trend in the proportion of potassium to sodium in the waters as TDS increase. The relative potassium abundance in samples from the McQueen Branch and the Crouch Branch Aquifers suggests that cation exchange has not played a dominant role in the evolution of these waters because it is usually the most tightly bound ion in cation-exchange reactions.

Sodium is clearly the dominant cation further down-dip in the Midville Aquifer (Strom and Kaback 1992). Cation exchange processes have led to water compositions downgradient from SRS comparable to those formed by exchange processes observed in other regions of the South Carolina Coastal Plain (Speiran and Aucott 1991).

Increases in the $\mathrm{HCO}_{3}^{-}$concentration in the Dublin-Midville Aquifer System occurs most often through the microbial oxidation of lignite within the aquifers (Murphy et al. 1992). The del ${ }^{13} \mathrm{C}$ signatures of the water are typically light, in the range of -20 to -25 parts per thousand (o/oo PDB). Usually these light values indicate an organic source of carbon rather than the dissolution of limestone or other bicarbonate ion source. Waters that have dissolved or reacted with carbonate minerals are usually relatively enriched in ${ }^{13} \mathrm{C}$ and have del ${ }^{13} \mathrm{C}$ values closer to the Peedee belemnite standard ( $\mathrm{del}{ }^{13} \mathrm{C}=0 \mathrm{o} / 00$ ). Although anomalous values are widely reported in the literature (Faure 1986) and other processes can decrease del ${ }^{13} \mathrm{C}$, the consistently light isotopic signature of SRS groundwaters suggests a dominantly organic origin for their dissolved inorganic carbon.

Dissolved oxygen is less than $0.1 \mathrm{mg} / \mathrm{L}$ for most of the samples from the Dublin-Midville Aquifer System. From Upper Three Runs Creek southward, the aquifers are anaerobic and contain abundant dissolved iron. The iron content in these aquifers is undesirably high, usually between 1 and $5 \mathrm{mg} / \mathrm{L}$. The anaerobic conditions allow the dissolved iron to remain in the ferrous form, but conditions have not yet become sufficiently anaerobic that sulfate has been reduced to the sulfide form.

Chapelle and Lovley (1990) have described a high-iron groundwater zone in the Middendorf Aquifer that is approximately 25 miles wide, extends across South Carolina from SRS to North Carolina, and is approximately parallel to the Fall Line. This high-iron zone is inferred to result from the reduction of iron oxyhydroxide grain coatings by bacteria during the oxidation of organic matter within the confined zones of the aquifer. Chapelle and Lovley (1992) propose that the activity of the ironreducing bacteria inhibit the activity of sulfate-reducing bacteria by keeping dissolved $\mathrm{H}_{2}$, formate, 
and acetate concentrations below threshold limits required by sulfate-reducing bacteria. Sulfate reduction begins further downgradient after the more easily oxidized organics have been consumed and the dissolved $\mathrm{H}_{2}$, formate, and acetate concentrations have increased. These observations are consistent with the observed high-iron zones in the Dublin-Midville Aquifer System and with the general chemistry of the waters (Strom and Kaback 1.992).

\section{GROUNDWATER MANAGEMENT}

\subsection{INTRODUCTION}

Groundwater management programs are generally aimed at two major concerns: the quantity of water used and the protection of water from contaminants generated by site activities.. At SRS water use management is not a compelling problem due to the abundance of high quality groundwater in the region. However, the existence of this groundwater resource at shallow depths (relative to other DOE facilities) underscores the importance of groundwater protection and remediation efforts.

The groundwater management program at SRS addresses both groundwater use and protection while placing a far greater emphasis on the later. Groundwater use is managed by the Site Services Department which monitors and reports water usage statistics and attempts to cut out waste wherever possible. Groundwater protection and monitoring responsibilities are spread among various operating departments (reactors, separations etc.) acting as custodians of facilities that could impact groundwater quality. The Environmental Restoration Department is responsible for monitoring and remediation at facilities no longer in operation. All of these departments depend on the Environmental Protection Department for sampling and analysis and for regulatory support.

The remainder of this document describes the elements of this groundwater management program in greater detail.

\subsection{GROUNDWATER USE}

Groundwater demand at SRS is in the billions of gallons. The site ranks as South Carolina's largest self-supplied industrial consumer of groundwater. Groundwater consumption is greatest in the separations facilities ( $F$ and H-Areas) and in $\mathrm{A} / \mathrm{M}$ Areas. Drinking water and process water is pumped from approximately 40 wells in widely scattered locations across the site. The wells range from 4" wells pumping as little as 10 GPM to 10 " wells pumping 1500 GPM. The large capacity wells are most commonly screened in the Crouch Branch Aquifer, but some pump from the McQueen Branch Aquifer. Only small capacity wells associated with small facilities like guard shacks and remote laboratories draw from the shallower aquifers. Information about individual wells can be found in the Environmental Protection Department's Well Inventory.

In 1988, SRS began reporting its water usage to the South Carolina Water Resource Commission. During that year the site used over 3.2 billion gallons of groundwater and over 50 billion gallons of river water. Demand for river water, which is used as reactor cooling water, has declined sharply since then. Groundwater demand has fluctuated as the site's mission has changed. In general, groundwater use declined by about $15 \%$ between 1988 and 1992 and then began to increase. In spite of mission changes and reductions in the work force, groundwater consumption rose to 3.5 billion gallons in 1994. Increased rates of consumption in F- and H-Areas appear to be the main contributors to the rise. 
The high rate of pumping has had only localized effects on water levels in the Cretaceous aquifers, and it is unlikely that water usage at SRS will ever cause drawdown problems that could impact the surrounding communities. For that reason, SRS does not need a comprehensive program aimed at managing water use.

However, SRS is taking some steps to control use. Metering devices have been installed on site water systems in order to keep more accurate records of water use. Early water use reports were based on estimates. The site is also making greater use of water towers to store water until it is needed. In the past, wells pumped continuously with excess water being diverted into ditches. SRS will continue to explore water conservation alternatives.

SRS is also making plans to centralize potable water production around a small number of wells located near A-Area. While this will not necessarily reduce the water demand, it will make it simpler to monitor drawdown effects from SRS's potable water use.

\subsection{GROUNDWATER PROTECTION}

\subsubsection{Groundwater Regulations}

At SRS, groundwater protection activities are mandated by a variety of state and federal regulations. The majority of the groundwater work is performed at units regulated by the South Carolina Hazardous Waste Management Regulations (SCHWMR) (1992). These regulations, promulgated pursuant to Sections 44-56-10 through 44-56-140 of the South Carolina Code of laws, implement the hazardous waste permitting program mandated by the federal Resource Conservation and Recovery Act (RCRA). There are ten (10) units at SRS that are impacted by the groundwater section of these regulations. Some of these units operate under Part B permits while others operate under state imposed "RCRA-like" regulation agreed to in Natural Resource Defense Council, Inc., et al. $v$. Herrington (1987).

Groundwater monitoring activities at nonhazardous waste disposal units are performed in compliance with those facilities' operating permits. The Interim Sanitary Landfill operates under state regulations R. 61-107.258. Solid Waste Management: Municipal Solid Waste Landfills. (1993). These regulations are equivalent to Subtitle D of RCRA. The Saltstone Disposal Facility operates under R61-66. South Carolina Industrial Solid Waste Disposal Site Regulation (1972).

More than fifty (50) sites at SRS are considered RCRA/CERCLA units. Groundwater concerns at these units are being addressed through an integration of RCRA and the Comprehensive Environmental Response Compensation Liability Act (CERCLA) (1980). This approach is mandated by the Federal Facility Agreement for the Savannah River Site. The RCRA/CERCLA units are listed in Appendix $\mathrm{C}$ of that agreement.

In some instances, groundwater conditions not covered by any of the above mentioned regulations are regulated by the South Carolina Pollution Control Act. Regulations governing the construction, maintenance, and abandonment of wells are contained in R.61-71.1 South Carolina Well Standards and Regulations.

\subsubsection{Sources of Contamination}

\subsubsection{SCHWMR/RCRA Units}

There are ten (10) units at SRS that are considered hazardous waste management units and are regulated by the state's SCHWMR and the federal government's RCRA regulations. The 
groundwater around each of these units is monitored by extensive well networks. Brief descriptions of each of these units follow below.

The M-Area Hazardous Waste Management Facility (HWMF) (904-51G, 904-112G) was active from 1958 to 1985, receiving wastes from electroplating operations in M Area. Those wastes are known to have included aluminum, lead, nickel, tetrachloroethylene, 1,1,1-trichloroethane, trichloroethylene, uranium, and other constituents (WSRC, 1993c). The compliance monitoring program at this unit is fully described in the RCRA Part B post-closure care permit application (WSRC, 1999a).

The F-Area Hazardous Waste Management Facility (HWMF) consists of the F-Area Seepage Basins (904-41G, 904-42G, 904-43G). The H-Area Hazardous Waste Management Facility (HWMF) consists of the H-Area Seepage Basins (904-44G, 904-45G, 904-46G, 904-56G). These two HWMFs are very similar in history and present similar groundwater concerns. The units operated from 1955 to 1988 and received low-level radioactive wastes and chemical wastes from chemical separations facilities. The compliance monitoring programs at these units are described in their approved RCRA Part B post-closure care permit applications (WSRC, 1999b, 1999c).

The Metallurgical Laboratory Hazardous Waste Management Facility. (settling basin 904-110G), received effluent from the Metallurgical Laboratory Building from 1956 to 1983. Most of the effluent was uncontaminated cooling water, however, small amounts of laboratory wastes also reached the basin. The basin underwent a RCRA closure in 1992. The compliance monitoring program at this facility is described in the 1992 RCRA Part B post-closure care permit application (WSRC, 1993c)

The Mixed Waste Management Facility (MWMF) received low-level radioactive-contaminated waste from 1972 until 1986. Protective clothing, lead shielding material, contaminated equipment, construction debris, and incidental waste from radiologically controlled areas were landfilled at this facility. The unit was identified as being subject to RCRA Subtitle $\mathrm{C}$ requirements in a consent decree between DOE and the Natural Resources Defense Council (NRDC) et al. (Civil Action 1:852583-6, U.S. District Court, District of South Carolina, Aiken Division) in May of 1988. Monitoring activities at the MWMF are described in the unit's assessment monitoring plan.

The Low Level Radioactive Waste Disposal Facility (LLRWDF) is adjacent to the MWMF. It received low level radioactive waste and some amount of solvent soaked rag waste. It is monitored in conjunction with the MWMF.

The Sanitary Landfill operated from 1974 to 1993. The unit received the types of waste associated with any municipal sanitary landfill; however, it also received solvent soaked rags and atomic wipes used for testing protective clothing. Disposal of the rags and wipes was disclosed to SCDHEC in 1990. This lead to a Settlement Agreement, Settlement Agreement 91-51-SW, that required WSRC to submit a Closure Plan and Postclosure Plan. (This agreement also applies to the LLRWDF.) The groundwater monitoring program at the Sanitary Landfill is fully described in the facility's quality assessment plan (WSRC,1995).

The F-, H-, K-, and P-Area Acid/Caustic Basins (904-74G, 904-75G, 904-80G, and 904-78G, respectively) were made subject to RCRA by Natural Resources Defense Council, et al $v$. Herrington (1987). These earthen basins were constructed in the 1950's. They received sulfuric acid and sodium hydroxide solutions from regeneration of ion exchange units, associated water rinses, condensate from steam heaters, and rainfall runoff from acid and caustic storage tanks within several areas at SRS (WSRC, 1993c). Three of the basins were taken out of service in 1982. The H-Area basin continued to receive steam condensate from a hose box and drainage from a chemical pad until 1985 (Heffner and Exploration Resources, 1991). The monitoring program at these units was set up by 
their groundwater quality assessment plan (WSRC, 1990), but that plan has been amended by the addition of new wells and by a reduction in the number analytes.

\subsubsection{Nonhazardous Permitted Units}

The Interim Sanitary Landfill is a northern, upgradient expansion of the Sanitary Landfill. This unit operated as the site's landfill from 1993 to 1994. It received no hazardous waste and is subject to the monitoring requirements of Subtitle D of RCRA. The monitoring program at this unit is described in the Interim Sanitary Landfill's operating permit (SCDHEC, 1995).

The Z-Area Saltstone Disposal Facility receives saltstone from the Saltstone Production Facility. The saltstone stabilizes low level radioactive evaporator bottoms from the $\mathrm{F} / \mathrm{H}$ Area Effluent Treatment Facility. In the future saltstone will contain decontaminated salts from the High Level Waste InTank Precipitator (ITP). This unit is operated under South Carolina industrial landfill regulations. The Z-Area Saltstone Disposal Facility's groundwater monitoring program, a combination of hydrocone sampling and well sampling, is described in the facility's operating permit (SCDHEC, 1995).

\subsubsection{RCRA/CERCLA Units}

In 1993 SRS entered into a Federal Facility Agreement with the EPA and SCDHEC. Under this agreement, about 90 units within SRS are listed as RCRA/CERCLA operable units. These units, listed in Appendix C of the FFA, must be subjected to RCRA Facility Investigations/Remedial Investigations (RFI/RIs). Investigations will involve soil and groundwater sampling and may lead to prolonged groundwater monitoring in some cases. More information about particular units can be found in their respective RFI/RI Workplans.

One of the RFI/RI units, Savannah River Laboratory Seepage Basins, was regulated as a RCRA-like unit under $N R D C$ et al $v$. Herrington until 1994 when it was added to Appendix $C$ of the FFA. These basins received liquid low level radioactive waste from 1954 to 1982 . Groundwater monitoring around these basins is described in the M-Area HWMF"s Part B Permit application (WSRC, 1987).

Appendix G of the FFA lists sites that have been designated Site Evaluation units. These sites are suspected to have been affected by hazardous or radioactive releases. They will undergo removal site evaluations and/or site evaluations that involve surficial soil sampling and soil gas surveys. A Site Evaluation unit can be placed on the Appendix C RCRA/CERCLA unit list if the site evaluation indicates the presence of significant contamination.

\subsubsection{Aquifer Vulnerability Mapping}

Aquifer vulnerability maps are being developed for use in planning future activities on site and for compliance with SCDHEC's proposed source water protection regulations. This is being done with a Geographic Information System (GIS) and a three-dimensional lithostratigraphic mapping approach called stacked-unit mapping. Stacked-unit mapping can portray a complex hydrogeologic setting in three-dimensions on one or more maps, and at the same time retain detail of point information while showing regional trends in data (chemical concentrations, water levels). The results of these efforts can be used in an ongoing effort to develop an optimal sitewide monitoring program that will augment the unit-specific monitoring driven by RCRA and CERCLA. The current program is described in section 2.3.3.2. 


\subsubsection{Maintenance of Natural Head Differences}

A comparison of the potentiometric surfaces of Aquifer Unit IB (Figure 2-1) and the overlying Aquifer Unit IIA (Figure 2-2) reveals that there are large areas within SRS where the hydraulic head is higher in the underlying unit (Figure 2-3). In those areas, flow between the two units would be upward providing a natural hydraulic barrier to the downward migration of contaminants through any breaches in Confining System I-II. This fortunate hydrologic circumstance was recognized early in the history of SRS.

In the 1980's DuPont began making conscious efforts to preserve the natural head differences. It was recognized that high capacity water wells could draw down the lower aquifer units and eliminate upward head conditions, so policy dictated that new water wells be screened in Aquifer Unit IA if they were to be located in areas where upward head was known to exist. This lowermost unit can easily supply the needed quantities of water without inducing downward head condition across Confining System I-II.

This well construction policy is still in place. An exception can be made when no groundwater contamination is present in the area or when the well is designed for low pumping rates.

\subsection{GROUNDWATER MONITORING PROGRAMI}

\subsubsection{Organization}

The SRS operates a centralized Groundwater Monitoring Program responsible for well installation, maintenance, and abandonments; sample collection and analysis; and data validation, storage, and reporting. The Environmental Monitoring Section (EMS) of the Environmental Protection Department (EPD) operates the Groundwater Monitoring Program.

\subsubsection{Well Siting, Construction, Maintenance \& Abandonment}

\subsubsection{New Well Siting}

All subsurface activities, including monitoring well installations and abandonments, require formal program plans. These program plans are reviewed by the Environmental Monitoring Section, the Savannah River Technology Center, and the Site Geotchnical Services Department. Well installations that are required by permits or RFI/RI workplans must have their locations approved by the appropriate regulators. The geology of the area, groundwater flow, and location of known contamination are considered in the final determination of the site location and location of wells.

\subsubsection{New Well Construction}

EPD/EMS personnel coordinate scheduling and implementation of field activities for new wells. WSRC Procedure Manual 3Q5 (WSRC, 1997) describes the process, inspections, and record keeping required for well installation. Most monitoring wells are constructed with 2" or 4" PVC and are equipped with dedicated submersible pumps. Geologic oversight personnel, independent of drilling personnel, are present during each well installation. Newly installed wells are surveyed by a qualified surveyor to obtain vertical and horizontal control points. Well construction and surveying data are recorded in a monitoring well installation report that includes general information, drilling and sampling information, geophysical logging, well installation materials, well development, and pump installation. EPD/EMS well drilling oversight personnel must review and accept the well construction records. 
In addition to the requisite SRS documentation, SCDHEC requires submission of a Water Well Record, Form DHEC \# 1903, describing the well construction, to SCDHEC within 30 days from the well installation or decommissioning date.

\subsubsection{Well Maintenance}

Wells in need of maintenance are usually identified during quarterly inspections of the monitoring wells by the groundwater samplers. Using forms from WSRC Procedure Manual 3Q5, the samplers document the need for maintenance, and repairs are scheduled and performed as needed.

\subsubsection{Well Abandonment}

When a well becomes obsolete, cannot be sampled because of extensive maintenance problems, or provides unreliable information, WSRC and SCDHEC negotiate the abandonment of the well. Abandonment information is recorded in the SRS Well Abandonment Report that includes project information and reason for abandonment in accordance with WSRC Procedure Manual 3Q5. Geologic oversight personnel, independent of drilling personnel, are present during each well abandonment. The EPD/EMS well drilling oversight personnel evaluate and approve the site after abandonment.

\subsubsection{Sampling}

\subsubsection{Sample Planning}

EPD/EMS personnel schedule groundwater sampling either as part of ongoing environmental screening or in response to specific requests from SRS personnel for hazardous waste facility monitoring or RFI requirements.

\subsubsection{Environmental Screening}

In 1984, WSRC established an environmental screening program for water quality analyses to maintain baseline groundwater quality information on each well and to identify and quantify groundwater environmental quality problems. This program supplements the monitoring required by regulatory drivers, and is intended to satisfy the requirements of DOE Order 5400.1. The screening program schedules wells to be sampled quarterly, semiannually, annually, or triennially. The environmental screening specifies minimum sampling and analysis of new wells, periodic monitoring of existing wells, and more frequent monitoring of wells in which certain contaminants have been detected.

Efforts to re-engineer the screening program are planned for the next several years. These efforts are described in sections 2.2.3 and 2.4.7.

\subsubsection{Compliance Monitoring}

The CERCLA, Geological, and Permitting Section of EPD is responsible for assuring that all compliance monitoring is initiated. This section determines what sampling is required by permits and regulatory agreements. The section assures that all required sampling requests are submitted and reviews each request to determine if all requirements are met. 


\subsubsection{Groundwater Investigation}

Many organizations at SRS submit sampling requests for groundwater investigations. These investigations include facility investigations, long-term monitoring, and basic research.

\subsubsection{Sampling Schedule Generation}

An annual schedule for sample collection and analysis is generated before the beginning of each calendar year, based on the routine monitoring program and custodian requests. This sampling schedule is updated during the calendar year to allow for changes in the monitoring requirements for each facility.

\subsubsection{Sample Collection and Field Measurements}

$*$

\section{Preparing for Sample Collection}

Chain-of-custody forms are generated based on the annual sampling schedule. The forms identify every sample to be collected from each well and the analyses to be conducted on each sample. Each form contains specific information about the sample, including the following: well name; type, number, and size of bottles; type of preservative; sampling company; analytical laboratory and sample name. Sections are provided for collection time and date and signatures to record custody transfer.

Analytical laboratories prepare and send bottles and shipping coolers to SRS. The bottles are certified clean and contain the required preservative for each type of analysis. Before going to the sampling location, sampling personnel prepare sampling kits with all necessary bottles.

\section{Sample Collection and Shipment}

EPD/EMS personnel and subcontactors collect groundwater samples using procedures contained in WSRC Procedure Manual 3Q5, Rev. 2 (WSRC, 1997). Sampling personnel use either a submersible pump or a dedicated hand bailer to retrieve water from each well and electric tapes to determine the water level in each well before purging the well. The sampler purges a minimum of two well volumes of groundwater prior to the collection to ensure that the sample is representative of water from a particular geologic formation. The $\mathrm{pH}$, turbidity, and specific conductance are measured after each well volume until stabilization to ensure that a representative sample has been obtained. The sampling personnel enter all field measurements into bound field logbooks.

Sampling personnel make entries on the bottle labels and chain-of-custody forms. The well name and sample date are entered onto the bottle label. The sampler's signature and the sample date and time are entered to initiate the chain-of-custody form.

Sampling personnel transport the samples in chilled coolers to a central location, where they are packaged, sealed, and labeled prior to shipment to analytical laboratories. Potentially radioactive samples are screened for total activity to determine appropriate packaging requirements. Relevant guidelines and regulations pertaining to shipping, packaging, and preservation of samples originate with the Department of Transportation and EPA. The chain-of-custody forms accompany the samples and are signed to record the transfer of samples from one person to another. 


\section{Blank Samples}

Field blanks are sample bottles of deionized water that accompany the sample bottles to the sampling location, during sampling, from the sampling location, in storage prior to shipment, and in transit to the labs. They provide a quality control check for contamination throughout the process. Except for volatile organic compounds, field blanks are normally analyzed for the same constituents as the samples taken in the field (see trip blanks below).

Equipment blanks are samples of deionized water that are opened at the sampling location and poured or pumped through the sampling device or metals filter to test for equipment contamination.

Trip blanks are sample bottles of deionized water that are placed in the shipping coolers along with groundwater samples. Trip blanks are required for each cooler containing samples that will be analyzed for volatile organics to check for contamination aquired in transit to the labs. Trip blanks are normally analyzed only for volatile organic compounds.

\subsubsection{Analysis}

\subsubsection{Laboratories}

Both commercial laboratories and the EPD/EMS laboratory analyze samples for the groundwater monitoring program. Commercial laboratories submit bids for contracts to perform analyses for the groundwater monitoring program. EPD/EMS evaluates the bids for technical merit, considering the experience of the laboratory, qualifications of the staff, suitability of the physical plant, analytical capabilities of the instrumentation, and cost. EPD/EMS staff visit each laboratory prior to awarding contracts to review the laboratory analytical procedures and quality assurance plans.

- Laboratories are required to maintain chain-of-custody forms for all samples shipped by SRS for analysis. The chain-of-custody form is initiated by the sampling crew and is forwarded to the laboratory with the sample. The receiving personnel at the laboratory sign the chain-of-custody form to indicate sample receipt, and a copy of the chain-of-custody form is retained by the laboratory. The original chain-of-custody form is returned to EPD/EMS. The laboratory is required to have a suitable internal tracking system to assure that each analytical result, associated with the proper sample, is returned to EPD/EMS. During periodic audits, EPD/EMS personnel verify each laboratory's sampletracking system.

EPD/EMS conducts annual performance reviews of laboratories. The reviews are designed to ensure that each laboratory maintains technical competence and follows the required QA plan and to address any problems identified by the QC samples. A follow-up evaluation is performed to ensure that the laboratory has addressed all findings.

\subsubsection{Analytical Methods}

EPA-approved methods or methods consistent with widely accepted standards or guidelines are used for analysis of SRS groundwater samples. These methods are typically found in Test Methods for Evaluating Solid Waste (EPA, 1986b), Methods of Chemical Analysis of Water and Wastes (EPA, 1979), Standard Methods for the Examination of Water and Wastewater (APHA, 1989), Environmental Measurements Laboratory Procedures Manual (DOE, 1990a), "National Emissions Standards for Emissions of Radionuclides Other than Radon from Department of Energy Facilities" (EPA, 1993a), "Test Methods for Measuring Radionuclide Emissions from Stationary Sources" (EPA, 1993b), Environmental Regulatory Guide for Radiological Effluent Monitoring and Environmental Surveillance (DOE, 1991), and "A Handbook of Radioactivity Measurements Procedures" (NCRP, 
1971). The methods and detection limits used by each laboratory are listed in the EPD/EMS quarterly groundwater reports. EPD/EMS requires that subcontracted laboratories be certified by the state in which the laboratory is located and by the state of South Carolina.

\subsubsection{WSRC Quality Control Samples}

Approximately five percent of the wells to be sampled in a quarter are designated as quality control wells. For these wells, EPD/EMS produces replicate samples in the form of blind duplicate and split samples. The bind duplicates are sent to the same laboratory as the primary sample. The split samples are sent to a different laboratory. Statistical analyses are performed on the analytical results of these samples as measures of precision, in the case of the blind duplicates, and accuracy in the case of the split samples.

EPD/EMS also ends its laboratories certified quality control standards for analysis each quarter. The laboratories analyze these standards without knowledge of their nominal concentrations. EPD/EMS uses the results of these analyses to evaluate the performance of each laboratory and initiate corrective action where necessary. Results of these analyses are published quarterly.

\subsubsection{Laboratory Quality Control Samples}

Analytical methods require the laboratories to analyze certain quality control samples (laboratory blanks, spiked samples, standards, laboratory duplicates, etc.) along with the groundwater samples. EPD/EMS requires the laboratories to report the results for these quality control samples along with the results from the groundwater samples. They are also required to use the quality control results to qualify the groundwater results.

\subsubsection{EPD/EMS Laboratory}

The EPD/EMS Laboratory implements a sample-tracking system for all samples analyzed on site. Chain-of-custody is tracked using an electronic system that documents sample collection, transport, analysis, and disposal. A computer automation program is used for all radiological samples.

After samples are transported to the laboratory, they are logged into the system by entering the sample location, the medium, and the collection date. After the samples are logged in, analysts working in the chemistry laboratories collect the samples for their laboratory from the collections room. The laboratory supervisor maintains a schedule documenting when samples are collected and designating what samples are to be analyzed in each of the chemistry laboratories.

In the chemistry laboratory, analysts log the samples into the laboratory. After completing the sample preparation, the samples are taken to the counting room, where counting-room analysts log the samples into the counting room for analysis. Throughout the sample preparation and analysis, the samples and aliquots maintain their unique identification numbers. When analyses are complete, the data are entered into the computer-automated system, thus completing the chain-ofcustody.

The Environmental Monitoring Computer Automation Program is the EPD/EMS laboratory information management system that efficiently manages sample scheduling, log-in, tracking, analytical results, and report generation. 


\subsubsection{Data}

\subsubsection{Data Collection}

\section{Field and Shipping Data}

Data entry personnel generate computer files of field and shipping data. The field data information includes well name, sample date, duplicate identifier, sample time, water temperature, total alkalinity, $\mathrm{pH}$, specific conductance, turbidity, depth to water, volume purged before sample collection, air temperature, method used for well purging and sampling, sampling program, sampler's initials, and status of the well. The shipping data include well name, sample date, and corresponding chain-of-custody number.

\section{Analytical Data}

All of the laboratories that analyze groundwater samples send electronic and hardcopy results of the analyses accompanied by case narrative reports. The laboratories are required by SRS to develop and institute data generation procedures designed to minimize data entry errors. The following information is included in the laboratory data files:

$\begin{array}{ll}\begin{array}{l}\text { customer sample identifier } \\ \text { chain-of-custody number }\end{array} & \begin{array}{l}\text { laboratory sample identification } \\ \text { laboratory replicate } \\ \text { sample collection date }\end{array} \\ \text { anample collection time } & \text { estimated quantitation limit } \\ \text { laboratory receipt date } & \text { detection limit } \\ \text { extraction date } & \text { EPA FG code } \\ \text { extraction time } & \text { EPA STORET code } \\ \text { extraction/digestion method } & \text { EMS Qual. code } \\ \text { analysis date } & \text { analytical result } \\ \text { analysis time } & \text { result units } \\ \text { analytical method } & \text { counting uncertainty } \\ \text { preparation batch } & \text { residual weight } \\ \text { laboratory } & \text { nominal concentration } \\ \end{array}$

\author{
percent recovery \\ lower acceptance limit \\ upper acceptance limit \\ dilution factor \\ instrument \\ instrument batch \\ analyst's initials \\ Wet or dry wt. indicator \\ bottle label number \\ sample matrix \\ preparation factor \\ subcontract number
}

\subsubsection{Data Validation and Verification}

To assess the completeness, accuracy, and precision of groundwater monitoring data, all of the data are subjected to a formal, systematic data validation and verification process in accordance with detailed implementing procedures. Validation and verification are distinct components of that process.

The laboratories perform data validation under the auspices of the groundwater monitoring program. Laboratory personnel apply statistical tests to address analyte presence or absence and variability, thereby assuring the acceptability of the data. Each test is sample- and analyte-specific and is designed to assess confidence in the analytical results based on the intended use of the data.

The objectives of data verification are to monitor adherence to contractual obligations or analytical method requirements and to assure that laboratory validation complies with EPA's Quality Assurance/Quality Control guidance. Verification assures that a data package is complete, contractually correct, internally consistent, and reported in a timely manner. Data management 
personnel verify data against prescribed requirements or specifications. The laboratories assign qualifier codes to identify the confidence level of the data and provide the user with information that takes into consideration the intended use of the data. Using computer programs, data management personnel check for anomalies in the data, compare historical results by well and analyte, and request a special review of the laboratory records and reanalysis of the sample if anomalies are detected or the historical results are considerably different.

Data management personnel review the field data to verify that field logs are complete and that trip blanks, field replicates, field blanks, and equipment rinsate blanks are present and to determine whether field measurements, such as $\mathrm{pH}$, fall within the range of valid values. Field and shipping data are compared electronically to verify sample dates and times and to ensure that the samples were shipped to the laboratory.

\subsubsection{Laboratory Data Records Reviews}

To ensure that results are correctly identified and quantified, data management personnel perform reviews of laboratory records on selected samples in accordance with detailed implementing procedures. Each review includes proofreading hard copy, reviewing initial and continuing calibration records, and checking the accountability and accuracy of associated blanks, spikes, and duplicate analyses.

\subsubsection{Data Storage}

Electronic data for samples collected since July 1, 1984, are stored in the Geochemical Information Management System (GIMS) database. Data control and change documentation are carefully controlled by the database software.

Data collected between 1952 and June 30, 1984, are available as data tables compiled for various reports. These data are of varying degrees of detail.

\subsubsection{Publications}

\section{$\underline{\text { Annual Environmental Report }}$}

A summary of groundwater monitoring is included. in the annual SRS environmental report as required by DOE Order 5400.1. The groundwater chapter of the report summarizes the results of groundwater monitoring during the year. The chapter also addresses the hydrogeology of SRS, the uses of groundwater near SRS, and changes in the groundwater monitoring program.

\section{Compliance and Investigation Reports}

Regulatory reports are written quarterly for specific RCRA sites. These reports include tables of field and analytical data, charts, and maps of the site, and they address changes that occur in the groundwater during the quarter.

\section{Quarterly Report}

The quarterly report summarizes the groundwater monitoring program conducted by SRS during the calendar quarter. It includes a description of the major components of the groundwater monitoring program; the presentation of the field, analytical, and quality control data for the quarter; and an analysis of the program's performance, field activities, and data produced. 


\section{Sampling Schedule}

The sampling schedule is compiled from sampling request and verification forms at the beginning of each calendar year. This is a working document that remains in draft until the end of the calendar year. It is updated throughout the year, with the changes distributed to well custodians. The document contains schedule tables that present a summary of the sampling scheduled for each well during the year. These schedule tables are also used as a basis for the database that produces the chain-of-custody forms. In addition, the schedule provides a comprehensive list of all analyses available in the groundwater monitoring program, an explanation and comprehensive list of semiannual and annual screening limits, an explanation of codes used in the schedule tables, rules for scheduiling analyses by environmental screening results, and descriptions of special studies conducted throughout the year.

\section{- Well Installation, Abandonment, and Maintenance Report}

The well installation, abandonment, and maintenance report is published annually to provide detailed information on well abandonment, maintenance, construction and stabilization, environmental soil borings, and surveying completed during the year.

\section{Well Inventory}

This semiannual report is an inventory of the wells recorded in EPD/EMS documents since the startup of SRS, including wells monitored by special request and research wells. For each series of wells, this report gives a description of the series, the building numbers of sites monitored by the wells, and a map showing the well locations. For each well, this report lists the well type, coordinates, screen zone elevation, ground elevation, top-of-casing elevation, casing type and size, installation date, abandonment date, and other information.

\subsection{SAMPLE OPTIMIZATION}

Since 1992 a sample optimization effort has been underway at SRS. The goal is to optimize the sampling efforts and minimize the cost of sampling in existing and future programs. The program is intended to assure that sampling.is performed only for specific reasons and that the sampling data meet data quality objectives. It is also intended to maximize the usefulness of today's sampling data for tomorrow's projects.

\subsubsection{RCRA Permit Activities}

Sampling at RCRA regulated units is constantly being examined to determine if it is yielding useful data. Where possible, nonproductive sampling is eliminated through permit modifications or changes in analytical methods. For instance, at the M-Area HWMF a more efficient approach has been taken to sampling of plume definition wells and wells potentially contaminated with PCBs. At F- \& HAreas, a substantial amount of money was saved by altering the analytical methods used for four radionuclides (243 Am, 241Pu, 242Pu, and 63Ni). And at the Sanitary Landfill HWMF, almost $60 \%$ of the monitoring wells were found to yield redundant data and were removed from the sampling schedule.

\subsubsection{RFI/RI Program}

Hydrocone and Hydropunch groundwater sampling techniques are being used extensively for plume definition on RFI/RI jobs. These fast and inexpensive sampling methods have greatly reduced 
reliance on traditional monitoring wells. They have also helped project teams to select optimal locations for what few wells they do install. When combined with quick turnaround analytical methods, hydrocone and hydropunch sampling can maximize the chances of completing all needed sampling during one phase of fieldwork. This cuts down on future mobilization costs.

\subsubsection{Environmental Screening Program}

The sitewide environmental screening program (described in section 2.3.3.2) was streamlined several years ago. The radiological and non-radiological programs were combined to eliminate redundant sampling. Total Activity Analysis replaced three analyses (tritium, gross alpha, and nonvolatile beta) once used to screen samples before shipment off site. The comprehensive sampling was changed from a two year cycle to a three year cycle. EMS has also reduced the number wells monitored in the program.

During the next several years, an effort will be made to develop a more systematic approach toward choosing the wells for the screening program. Specific sites near seeplines and drinking water supply wells will be targeted for sampling. At the same time, screening program sampling will be curtailed at sites already covered by other monitoring programs (RCRA, CERCLA, etc.). Efforts will also be made to simplify screening data retrieval and analysis. Analysis of the data will be presented in regular reports.

\subsection{GROUNDWATER REMEDIATION}

\subsubsection{M-Area HWMF}

Remediation of the M-Area solvent plume began with the installation of one recovery well and a pilot air stripper in 1982-83. A full scale air stripper (the M-1 air stripper) was put into service in 1985. It is located inside M-Area and is fed by eleven recovery wells. The M-1 stripper operates at approximately $500 \mathrm{gpm}$. A second stripper (the A-2 air stripper) is fed by six recovery wells. It is located near SRTC and operates at approximately $300 \mathrm{gpm}$.

Additional groundwater remediation methods are being tested. These include recirculation wells, multistage aerators and dynamic underground stripping.

Soil vapor extraction (SVE) is also underway at M-Area. Dry vadose zone wells, both vertical and horizontal, are plumbed into vaccum extraction units at five locations. These units will remove solvent from the soil of the vadose zone before it reaches the underlying groundwater. A detailed description of the corrective actions at M-Area can be found in the 1992 RCRA Part B Permit Renewal Application, Volume III: M-Area Hazardous Waste Management Facility, Rev. 12 ( WSRC, 1999).

\subsubsection{Metallurgical Laboratory HWMF}

At the Metallurgical Laboratory HWMF two recovery wells are nearing completion. They will pump solvent contaminated water to the M-1 stripper for treatment. A detailed description of the corrective actions at the Met Lab can be found in the 1992 RCRA Part B Permit Renewal Application Volume XIV: Metallurgical Laboratory Hazardous Waste Management Facility, Rev. 4 (WSRC, 1998). 


\subsubsection{H-Area HWMF}

At the H-Area HWMF, 135 gpm of contaminated groundwater is being removed from the subsurface by 8 extraction wells. The water is then treated for metals and radionuclides by reverse osmosis and ion exchange and returned to the aquifer through 15 upgradient injection wells. The water contains tritium, which cannot be removed by any known treatment; however, the continuous cycle of pumping and reinjection will hydraulically control the tritium plume until it is attenuated by natural radioactive decay. A detailed description of the corrective actions at $\mathrm{H}$-Area can be found in the 1992 RCRA Part B Permit Renewal Application, Volume V: H-Area Laboratory Hazardous Waste Management Facility, Rev. 10 (WSRC, 1999).

\subsubsection{F-Area HWMF}

At the F-Area HWMF, the same process is being used. At that unit $165 \mathrm{gpm}$ is being pumped from 9 extraction wells and reinjected after treatment into 9 injection wells. A detailed description of the corrective actions at F-Area can be found in the 1992 RCRA Part B Permit Renewal Application Volume IV: F-Area Laboratory Hazardous Waste Management Facility, Rev. 10 (WSRC, 1999).

\subsubsection{TNX Groundwater}

At TNX, 4 recovery wells pump contaminated groundwater to the T-1 Air Stripper where it is treated for VOC's. The system operates at about $75 \mathrm{gpm}$. A more passive system is being tested nearby where water is drawn into subsurface columns of iron shavings by siphoning. TCE undergoes chemical breakdown in contact with the iron. This new technology is known as the "Geosiphon". Soils vapor extraction is also being tested at TNX.

\subsubsection{Other Units}

Corrective actions are being designed for numerous other units as part of the CERCLA process. The specifics of those actions are presented in the proposed plans and records of decision for those units.

\subsection{DECONTAMINATION AND DECOMMISSIONING}

Decommissioning, conducted to reduce the potential for negative health and safety impacts of SRScontaminated facilities, includes stabilization, reduction, or removal of radioactive or hazardous materials or demolition of the facilities.

More than 600 SRS facilities contain contamination from radioactive materials, or from hazardous materials such as asbestos. These include reactors, chemical separation facilities, metal-forming facilities, office buildings, diesel generator houses, and power substations and transformers.

The Transition, Decontamination, and Decommissioning (TD\&D) Department was established in late 1993 , and by 1994 a number of programs were initiated. One of the key projects was the demolition of six R-Reactor auxiliary buildings and a chemical silo. Another major D\&D job involved the demolition of four auxiliary buildings at the Heavy Water Components Test Reactor. This was the first phase of $D \& D$ work on a 1950 's-vintage heavy water test reactor. At the beta-gamma incinerator decontamination of some areas has been completed in preparation for $D \& D$ in the process area. 
Demolition of the old tritium facility (232-F) was completed in 1997. In addition, TD\&D is negotiating with outside vendors to remove surplus powerhouses. 


\section{REFERENCES CITED}

Aadland, R. K., J. A. Gellici, and P. A. Thayer. 1994 Hydrogeologic Atlas of West-Central South Carolina (U) WSRC TR--94-0429. Westinghouse Savannah River Company, Aiken, SC.

Aadland, R. K., and H. W. Bledsoe, 1990a, Classification of hydrostratigraphic units at the Savannah River Site, South Carolina, USDOE Report, WSRC-RP-90-987, Westinghouse Savannah River Co., Westinghouse Savannah River Laboratory, Aiken, SC 29808, 15.

Aadland R. K., and H. W. Bledsoe, 1990b, Hydrostratigraphy of the Coastal Plain Sequence, Savannah River Site (SRS), South Carolina; GSA Abstracts with Programs, v. 22, no. 7.

Aadland, R. K., A. D. Smits, and P. A. Thayer, 1992, Geology and Hydrostratigraphy of the A/M Area, Savannah River Site (SRS), South Carolina (U), USDOE Report WSRC-RP-92-440, Westinghouse Savannah River Company, Savannah River Site, Aiken, SC 29808, 104.

Albenesius, P. W., M. B. Amidon, and T. F. Gaughan, 1990, HSB 84A pumping test (U), USDOE Report WSRC-TR-90-313, Westinghouse Savannah River Company, Savannah River Site, Aiken, SC $29808,18$.

Aller, L., T. Bennett, J. H. Lehr, R. J. Petty and G. Hackett. 1987. DRASTIC: A Standardized System for Evaluating Ground Water Pollution Potential Using Hydrogeologic Settings. EPA-600/287-035. National Water Well Association, Dublin, OH and Robert S. Kerr Environmental Research Laboratory, U. S. EPA, Ada, OK.

APHA (American Public Health Association), 1989. Standard Methods for the Examination of Water and Wastewater, 17th Edition. American Public Health Association, Washington, D.C.

Aucott, W. R., 1988, The predevelopment ground water flow system and hydrologic characteristics of the Coastal Plain aquifers of South Carolina, U.S. Geological Survey, Water-Resources Investigations Report 86-4347, 66.

Aucott, W. R., M. E. Davis, and G. K. Speiran, 1987, Geohydrologic framework of the Coastal Plain aquifers of South Carolina, U.S. Geological Survey Water-Resources Investigations Report 85-4271.

Aucott, W. R., and G. K. Speiran, 1985a, "Groundwater flow in the Coastal Plain aquifers of South Carolina", Journal of Ground Water, v. 23, no. 6, 736-745.

Aucott, W. R., and G. K. Speiran, 1985b, Potentiometric surfaces of November 1982 and declines in the potentiometric surfaces between the period prior to development and November 1982 for the Coastal Plain aquifers of South Carolina, U.S. Geological Survey Water-resources Investigations Report 84-4215, 7 sheets.

Back, William, 1966, Hydrochemical Facies and Ground-water Flow Patterns in Northern Part of Atlantic Coastal Plain, U.S.G.S. Professional Paper 498-A, Washington, DC., U.S. Government Printing Office

Beard, D. C., and P. K. Weyl, 1973, "Influence of Texture on Porosity and Permeability of Unconsolidated Sand", American Association of Petroleum Geologists Bulletin, 57: 349-369.

Bledsoe, H. W., 1988, SRP Baseline Hydrogeologic Investigation - Phase III, Savannah River Laboratory Report DPST-88-627, E.I. du Pont de Nemours \& Co.,.Aiken, SC 29808. 
Bledsoe, H.W., 1988, SRP Baseline Hydrogeologic Investigation-Phase II, DPST-87-674, E.I. DuPone de Nemours \& Co., Savannah River Laboratory, Aiken, SC 29808, ca. 300.

Bledsoe, H. W., 1987, SRP Baseline Hydrogeologic Investigation - Phase II, Savannah River Laboratory Report DPST-86-674 E.I. du Pont de Nemours \& Co., Aiken, SC 29808.

Bledsoe, H.W., 1986, SRP Baseline Hydrogeiologic Investigation - Phase II, E.I. DuPone de Nemours \& Co., Savannah River Laboratory, Aiken, SC 29808, ca. 300.

Bledsoe, H. W., R. K. Aadland, and K. A. Sargent, 1990, Baseline Hydrogeologic Investigation Summary Report, USDOE Report WSRC-RP-90-1010, Westinghouse Savannah River Company, Aiken, SC 29808, app. 200.

Brooks, M.J., and Sassaman, K.E., 1990, Point bar geoarchaeology in the Upper Coastal Plain of the Savannah River Valley, South Carolina, a case study, in Lasca, N.P., and Donahue, J., eds., Archaeological Geology of North America: Gelogical Society of America Centennial Special Publication No. 4, p. 183-197.

Burt, R. A., 1987, "Proposed Criteria for Nomenclature-Draft", South Carolina Hydrostratigraphic Subcommittee, July 23, 1987.Cahill, J. M., 1982. Hydrology of the Low Level Radioactive Solid Waste Burial Site and Vicinity near Barnwell, South Carolina, USGS Open File Report 82-863, U.S. Geological Survey, Government Printing Office, Washington, DC.

Butler, J. R., 1979. "The Carolina Slate Belt in North Carolina and Northeastern South Carolina: A Review," Geological Society of America Abstracts with Program. 11: 172.

Chapelle, F.H. and D.R. Lovley, 1990, Competitive exclusion of sulfate reduction by Fe(III)-reducing bacteria: a mechanism for producing discrete zones of high-iron ground water, Eos Trans., AGU, v. $71,1319$.

Chowns, T. M., and C. T. Williams, 1983. "Pre-Cretaceous Rocks Beneath the Georgia Coastal Plain-Regional Implications," Studies Related to the Charleston, South Carolina, Earthquake of 1886-Tectonics and Seismicity. ed., G. S. Ghon, U.S. Geological Survey Professional Paper 1313, L1-L42.

Christensen, E. J., and D. E. Gordon, 1983, "Technical Summary of Groundwater Quality Protection Program at Savannah River Plant", Vol. I, Site Geohydrology and Solid and Hazardous Wastes, Savannah River Laboratory Report DPST-83-929, E. I. duPont de Nemours and Co., Aiken, SC 29808.

Christopher, R. A., 1982, "Palynostratigraphy of the basal Cretaceous unit of the eastern Gulf and southern Atlantic Coastal Plains": in Arden D. D., Beck, B. F., and Morrow, Eleanore, eds., Proceedings, Second symposium on the geology of the Southeastern Coastal Plain, Georgia Geological Survey Information Circular 53, 10-23.

Clarke, J. S., R. Brooks, and R. E. Faye, 1985, Hydrogeology of the Dublin and Midville Aquifer Systems of east-central Georgia, Georgia Geological Survey Information Circular 74.

Colquhoun, D. J., and H. S. Johnson, Jr., 1968, "Tertiary Sea-Level Fluctuation in South Carolina", Palaeogeography, Palaeoclimatology, Palaeoecology, v. 5, 105-126. 
Colquhoun, D. J., I. D. Woollen, D. S. Van Nieuwenhuise, G. G. Padgett, R. W. Oldham, D. C. Boylan, J.W. Bishop, and P. D. Howell, 1983, Surface and subsurface stratigraphy, structure and aquifers of the South Carolina Coastal Plain, SCDHEC Report ISBN 0-9613154-0-7, 78.

Cooke, C. W., 1936, Geology of the Coastal Plain of South Carolina, U.S. Geological Survey Bulletin 867, 196p.

D'Appolonia, Inc., 1981, Report, DWPF-Stage 1 Investigation Aquifer Performance Tests, 200-S Area, Savannah River Plant, South Carolina, Project No. 76-372, Pittsburgh, PA.

Daniels, D. L., 1974. "Geologic Interpretation of Geophysical Maps, Central Savannah River Area, South Carolina and Georgia." U.S. Geological Survey, Geophysical Investigation Map GP-893.

Daniels, D. L., I. Zietz, and P. Popenoe, 1983. "Distribution of Subsurface Lower Mesozoic Rocks in the Southeastern United States, as Interpreted from Regional Aeromagnetic and Gravity Maps," Studies Related to the Charleston, South Carolina, Earthquake of 1886--Tectonics and Seismicity. ed., G. S. Gohn, U.S. Geological Survey Professional Paper 1313, K1-K24.

DOE (Department of Energy), 1985. Application for a Post-Closure Permit, M-Area Hazardous Waste Management Facility, Vol. III, Savannah River Plant, Department of Energy, Savannah River Plant, Aiken, SC.

DOE (U.S. Department of Energy), 1988. General Environmental Protection Program, DOE Order 5400.1. U.S. Department of Energy, Washington, D.C.

DOE (U.S. Department of Energy), 1990a. Environmental Measurements Laboratory Procedures Manual, HASL-300, 27th Edition, Volume I. U.S. Department of Energy, New York, NY.

DOE (U.S. Department of Energy), 1990b. Radiation Protection of the Public and Environment, DOE Order 5400.5. U.S. Department of Energy, Washington, D.C.

DOE (U.S. Department of Energy), 1991. Environmental Regulatory Guide for Radiological Effluent Monitoring and Environmental Surveillance. U.S. Department of Energy, Washington, D.C.

Dupont, 1986, Hydrogeologic Conditions and Evaluation of Chemical Transport in the Vicinity of the M-Area Settling Basin and Lost Lake, CORR-86-0396, Report by S.S. Papadopulos and Associates for E.I. du Pont de Nemours and Company, Savannah River Laboratory, Aiken, SC 29808.

Eddy, C. A., B. B. Looney, J. M. Dougherty, T. C. Hazen, and D. S. Kaback, 1991, Characterization of the Geology, Geochemistry, Hydrology and Microbiology of the In-Situ Air Stripping Demonstration Site at the Savannah River Site, USDOE Report WSRC-RD-91-21, Westinghouse Savannah River Co., Savannah River Laboratory, Aiken, SC 29808, 118.

EPA, 1985. Draft--Proposed Low-Level Radioactive Waste Standards: Background Information Document, 40 CFR 193, March 13, 1985, U.S. Environmental Protection Agency, Office of Radiation Programs, Washington, DC.EPA (U.S. Environmental Protection Agency), 1979. Methods for Chemical Analysis of Water and Wastes, EPA-600/4-79-020. U.S. Environmental Protection Agency, Washington, D.C.

EPA (U.S. Environmental Protection Agency), 1986a. RCRA Groundwater Monitoring Technical Enforcement Guidance Document, OSWER-9950.1. U.S. Environmental Protection Agency, Washington, D.C. 
EPA (U.S. Environmental Protection Agency), 1986b. Test Methods for Evaluating Solid Waste, SW-846, Volumes 1A, 1B, 1C, third edition. U.S. Environmental Protection EPA (U.S. Environmental Protection Agency), 1992. Code of Federal Regulations, Title 40, Part 264, Appendix IX, "Standards for Owners and Operators of Hazardous Waste Treatment, Storage, and Disposal Facilities," pp. 324-330. U.S. Environmental Protection Agency, Washington, D.C.

EPA (U.S. Environmental Protection Agency), 1993a. Code of Federal Regulations, Title 40, Part 61, Subpart H, "National Emission Standards for Emissions of Radionuclides Other Than Radon From Department of Energy Facilities" pp. 49-52. U.S. Environmental Protection Agency, Washington, D.C.

EPA (U.S. Environmental Protection Agency), 1993b. Code of Federal Regulations, Title 40, Part 61, Appendix B, Method 114, "Test Methods for Measuring Radionucluide Emissions from Stationary Sources," pp. 256-264. U.S. Environmental Protection Agency, Washington, D.C.

EPA (U.S. Environmental Protection Agency), 1992. Code of Federal Regulations, Title 40, Part 264, Appendix IX, "Standards for Owners and Operators of Hazardous Waste Treatment, Storage, and Disposal Facilities," pp. 324-330. U.S. Environmental Protection Agency, Washington, D.C.

Evans, E. K. and R. R. Parizek, 1989, Analysis of Single-Well Aquifer Tests Conducted at the Burial Grounds, Savannah River Site, SRL-ESS-89-578, Westinghouse Savannah River Companny, Aiken, SC 29808.

Fallaw, W. C., V. Price, and P. Thayer, 1990, "Stratigraphy of the Savannah River Site, South Carolina", Proceedings of the Second Bald Head Island Conference on Coastal Plains Geology, November 6-11, 1990, Addendum, 1-4.

Faye, R. E., and D. C. Prowell, 1982, Effects of Late Cretaceous and Cenozoic Faulting on the Geology and Hydrology of the Coastal Plain Near the Savannah River, Georgia, and South Carolina, U. S. Geological Survey Open File Report 82-156.

Folk, R. L., and W. C. Ward, 1957, "Brazos River Bar: A Study in the Significance of Grain Size Parameters", Journal of Sedimentary Petrology, 27: 3-26.

Folk, R. L., 1954, "The Distinction Between Grain Size and Mineral Composition in Sedimentary Rock Nomenclature", Journal of Geology, 62: 345-351.

Freeze, R. A., and J. A. Cherry, 1979, Groundwater, Prentice Hall Inc. Englewood Cliffs, NJ.

Geomatrix Consultants. 1993. Preliminary Quaternary and Neotectonic Studies: Savannah River Site , South Carolina. Project No. 1988. Prepared for Lawrence Livermore National Laboratory, Purchase Order No. B160449; Westinghouse Savannah River Company, Aiken, SC.

GeoTrans, Inc., 1988, "Characterization of Ground Water Flow and Transport in the General Seperations Area. Savannah River Plant, Effects of Closure Options on Groundwater Flow at the FArea Seepage Basins".

GeoTrans, Inc., 1989, "Characterization of Groundwater Flow and Transport in General Separations Area. Savannah River Plant, Effluents of Closure Options on Groundwater Flow at H-Area Seepage Basins. 
Geraghty \& Miller, Inc. 1983, Tuscaloosa Aquifer Pumping Test, M-Area, Savannah River Plant, April 1983, E.I. du Pont de Nemours Co., Atomic Energy Division, Aiken, SC 29808, 24.

Geraghty \& Miller, Inc. 1986, Hydraulic Properties of the Tertiary Aquifer System Underlying the A/M Area, E.I. Dupont de Nemours Co., Atomic Energy Division, Aiken, SC 29808, 56.

Gohn, G. S., 1983, ed. "Studies Related to the Charleston, South Carolina, Earthquake of 1886Tectonics and Seismicity." U.S. Geological Survey Professional Paper 1313.

Grubb, H. F., 1986, Gulf Coast regional aquifer-system analysis - A Mississippi perspective, U. S. Geological Survey Water-Resources Investigations Report 86-4162, 22p.

Hantush, M. S. and C. E. Jacob. 1955. "Non-steady radial flow in an infinite leaky aquifer." Transactions of the American Geophysical Union. 36:95-100.

Haselow, J. S., 1991, Report in preparation documenting current status and results of groundwater modeling in the A/M Area, SRS, personal communication.

Heffner, J. D., and Exploration Resources, Inc., 1991. Technical Summary of Groundwater Quality Protection Program at the Savannah River Site (1952-1986), Volume I-Site Geohydrology and Waste Sites, DPSP-88-1002. Westinghouse Savannah River Company, Savannah River Site, Aiken, SC.

Hem, J. D., 1970, Study and Interpretation of the Chemical Characteristics of Natural Water, 2nd ed., U. S. Geological Survey Water-Supply Paper 1473, 363p.

Heron, S. D., 1958, "History of terminology and correlations of the basal Cretaceous formations of the Carolinas", South Carolina State Development Board, Div. of Geology, Geologic Notes, v. 2, 77-88.

Hiergesell, R. A. 1993. Hydrologic Analysis of Data for the Lost Lake Aquifer Zone of the Steed Pond Aquifer at Recovery Well RWM-16 (U). Technical Report WSRC-TR-92-529. Westinghouse Savannah River Company, Aiken, SC 29808.

Hiergesell, R. A. 1994. Hydrologic Analysis of Data from the Lower Lost Lake Aquifer at Recovery Well RWM-12 (U). Technical Report WSRC-TR-93-666. Westinghouse Savannah River Company, Aiken, SC 29808.

Hiergesell, R. A., R. L. Nichols, R. Ridgway, C. P. May and B. Pemberton. 1994. Report of Recovery Well Testing in the Northern A/M Area (U). Technical Report WSRC-TR-94-0424. Westinghouse Savannah River Company, Aiken, SC 29808.

Hubbard, J. E., 1986, An Update on the SRP Burial Ground Area Water Balance and Hydrology, DPST-85-958.

Logan, W. R. and G. M. Euler, 1989, Geology and Ground-Water Resources of Allendale, Bamberg, and Barnwell Counties and part of Aiken County South Carolina, Water Resources Commission Report No. 155, 113.

Marine, I. W., 1979, "The Use of Naturally Occurring Helium to Estimate Groundwater Velocities for Studies of Geologic Storage of Radioactive Waste", Water Resources Research, v. 15(5), 1130-1136. 
Marine, I.W., 1976, Geochemistry of Ground Water at the Savannah River Plant, DP-1356, E.I.Du Pont de Nemours and Co., Savannah River Laboratory, Aiken South Carolina 29801.

Marine, I. W., 1975, "Water level fluctuations due to earth tides in a well pumping from slightly fractured crystalline rock", Water Resources Research, v. 11, 165-173.

Marine, I. W., and G. E. Siple, 1974, "Buried Triassic basin in the central Savannah River area, South Carolina and Georgia", Geological Society of America Bulletin, v. 85, 311-320.

Marine, I. W., 1974, "Geohydrology of buried Triassic basin at Savannah River Plant, South Carolina", American Association of Petroleum Geologists Bulletin, v. 58, 1825-1837.

Marine, I. W.,1973, Hydrology of buried crystalline rock at the Savannah River Plant near Aiken, South Carolina, DOE/SR_WM-79-2, U.S. Geological Survey Water Resources Division.

Marine, I. W., 1967a, "The permeability of fractured crystalline rock at the Savannah River Plant near Aiken, South Carolina", Geological Survey Research 1967, Chapter B, U.S. Geological Survey Professional Paper 575-B, B203-B211.

Marine, I. W.,1967b, "The use of tracer test to verify an estimate of groundwater velocity in fractured crystalline rock at the Savannah River Plant near Aiken, South Carolina", In Isotope Techniques in the Hydrologic Cycle: Geophysical Monograph Series, v. 11, ed., G. E. Stout, Washington, DC, American Geophysical Union, 171-178.

Marine, I. W., 1966, "Hydraulic correlation of fracture zones in buried crystalline rock at the Savannah River Plant near Aiken, South Carolina", Geological Survey Research 1966, Chapter D, U.S. Geological Survey Professional Paper 550-D, D223-D227.

Meisler, H., 1980, Plan of study for the northern Atlantic Coastal Plain regional aquifer system analysis, U.S. Geological Survey Water-Resources Investigations Report 80-16, 27.

Miller, J. A., 1985, Hydrogeologic Framework of the Floridan Aquifer System in Florida and in Parts of Georgia, Alabama, and South Carolina, U.S. Geological Survey Professional Paper 1403-B, 91.

Miller, J. A, and R. A. Renken, 1988, Nomenclature of Regional Hydrogeologic Units of the Southeastern Coastal Plain Aquifer System, U. S. Geological Survey, Water-Resources Investigations Report 87-4202, 21.

Murphy, C.E.,jr., L.R. Bauer, D.W. Hayes, W.L. Marter, C.C. Zeigler, D.E. Stephenson, D.D. Hoel, D.M. Hamby, 1990, Tritium in the Savannah River Site Environment (U), WSRC-90-424-1, Westinghouse Savannah River Co., Aiken, SC, 29808, ca. 150.

Nystrom, P. G., Jr., R. H. Willoughby, and L. E. Kite, 1986, "Cretaceous-Tertiary stratigraphy of the upper edge of the Coastal Plain between North Augusta and Lexington South Carolina", Carolina Geological Society Field Trip Guidebook, South Carolina Geological Survey.

Odom, A. L., and P. D. Fullagar, 1973. "Geochronologic and Tectonic Relationships Between the Inner Piedmont, Brevard Zone, and Blue Ridge Belts, North Carolina," American Journal of Science. 273-A: 133-149..

Overstreet, W. C., and H. Bell, II., 1965. "The Crystalline Rocks of South Carolina." U.S. Geological Survey Bulletin 1183. 
Owens, J.P., 1989, Geologic map of the Cape Fear region, Florence $1^{\circ} \times 2^{\circ}$ quadrangle and northern half of the Georgetown $1^{\circ} \times 2^{\circ}$ quadrangle, North Carolina and South Carolina: U.S. Geological Survey Miscellaneous Investigations Series Map I-1948-A.

Parizek, R. R., and R. W. Root, 1986, Development of a Ground Water Velocity Model for the Radioactive Waste Management Facility, Savannah River Plant, Aiken, South Carolina, USDOE Report DPST-86-658, E. I. du Pont de Nemours \& Company, Savannah River Laboratory, Aiken, SC 29808.

Park, A. D., 1980, The ground-water resources of Sumter and Florence Counties, South Carolina, South Carolina Water Resources Commission Report No. 133, Columbia, SC., 43.

Popenoe, P., and I. Zeitz, 1977. "The Nature of the Geophysical Basement Beneath the Coastal Plain . of South Carolina and Northeastern Georgia," Studies Related to the Charleston, South Carolina, Earthquake of 1886--A Preliminary Report. ed., D. W. Rankin, U.S. Geological Survey Professional Paper 1028, 119-137.

Prowell, D. C., 1994a, Preliminary Geologic Map of the Savannah River Site, Aiken, Allendale, and Barnwell Counties, South Carolina, U. S. Geological Survey, Open-File Report 94-181, 15 pp.

Prowell, D. C., R. A. Christopher, L. E. Edwards, L. M. Bybell, and H. E. Gill, 1985a, "Geologic section of the updip Coastal Plain from central Georgia to western South Carolina", USGS Miscellaneous Field Studies, Map MF-1737.

Prowell, D. C., L. E. Edwards, and N. O. Frederiksen, 1985b, The Ellenton Formation in South Carolina--A revised age designation from Cretaceous to Paleocene, U.S. Geological Survey Bulletin 1605-A, A63-A69.

Ruffin, E., 1843, Report of the commencement and progress of the agricultural survey of South Carolina of 1843, Columbia, South Carolina, 56.

S\&ME Inc., 1988a, "Borehole Permeability Analysis for Burial Ground Parameter Wells at the Savannah River Plant, Aiken, South Carolina".

S\&ME Inc, 1988b, "Borehole Permeability Analysis F-Area Assessment Wells at the Savannah River Plant, Aiken, South Carolina".

SCDHEC (South Carolina Department of Health and Environmental Control), 1986. Construction Permit 12,076. Columbia, SC.

SCDHEC (South Carolina Department of Health and Environmental Control), 1987a. Construction Permit 13,173. Columbia, SC.

SCDHEC (South Carolina Department of Health and Environmental Control), 1987b. Hazardous Waste Permit SC1-890-008-989. Office of Environmental Quality Control, Bureau of Solid and Hazardous Waste Management, Columbia, SC.

SCDHEC (South Carolina Department of Health and Environmental Control), 1991. Sanitary Landfill Domestic Waste Permit 87A. Columbia, SC. 
SCDHEC (South Carolina Department of Health and Environmental Control), 1992a (modification effective date). Hazardous Waste Permit SC1-890-008-989. Office of Environmental Quality Control, Bureau of Solid and Hazardous Waste Management, Columbia, SC.

SCDHEC (South Carolina Department of Health and Environmental Control), 1992b. South Carolina Hazardous Waste Management Regulations, R.61.79.124, .260 through .266, .268, and .270. Columbia, SC.

Seaber, P.R., F. P. Kapinos, and G. L. Knapp, 1987, Hydrologic Unit Maps, U.S. Geological Survey Water Supply Paper W2294, U. S. Geological Survey, REston VA, 63 pp.

Siple, G. E., 1967, Geology and ground water of the Savannah River Plant and vicinity, South Carolina, U.S. Geological Survey Water-Supply Papes: 1841, 113.

Sirrine Environmental Consultants, 1987, "F-Area Compliance Monitoring Program Field Permeability Tests".

Sirrine Environmental Consultants, 1988a, "Field Permeability Tests H-Area Seepage Basins Savannah River Plant".

Sirrine Environmental Consultants, 1988b, "Field Permeability Tests H-Area Seepage Basin Plume Assessment Well Savannah River Plant".

Sirrine, 1991, 1992 RCRA Part B Permit Renewal Application (U), M-Area Hazardous Waste Management Facility. (Draft), 300.

Sloan, E., 1908, Catalog of the mineral localities of South Carolina, South Carolina Geological Survey Bulletin 2, 505.

Smith, G. W., III, 1979, Lithostratigraphic relationships of Coastal Plain units in Lexington County and adjacent areas, South Carolina, M.S. thesis, University of South Carolina, Department of Geology, Columbia, SC, 139.

Speiran, G.K., and W.R. Aucott, 1991, Effects of Sediment Depositional Environment and Groundwater Flow on the Quality and Geochemistry of Water in Aquifers in Sediments of Cretaceous Age in the Coastal Plain of South Carolina, U.S.G.S. Open-File Report, 91-202, 77.

Stringfield, V. T., 1966, Artesian water in Tertiary limestone in the Southeastern States, U.S. Geological Survey Professional Paper 517, 226.

Strom, R. N., and D. S. Kaback, 1992, SRP Baseline Hydrogeologic Investigation: Aquifer Characterization, Groundwater Geochemistry of the Savannah River Site and Vicinity, WSRC-RP92-450, Westinghouse Savannah River Company, Aiken, SC 2980896.

Swift, D. J. P., and S. D. Heron, 1969, "Stratigraphy of the Carolina Cretaceous", Southeastern Geology, v. 10, 201-245.

Trask, P. D., 1930, "Mechanical Analysis of Sediments by Centrifuge”, Economic Geology 25: 581-599.

Wait, R. L., and M. E. Davis, 1986, Configuration and hydrology of the pre-Cretaceous rocks underlying the Southeastern Coastal Plain Aquifer System, U.S. Geological Survey Water-Resources Investigations Report 86-4010, 1 sheet. 
$\overline{\text { Webster, D. S., Proctor, J. R., and I. W. Marine, 1970, Two-well tracer test in fractured crystalline }}$ rock, U.S. Geological Survey Water-Supply Paper 1544-I.

WSRC (Westinghouse Savannah River Company), 1990. Mixed Waste Management Facility (MWMF) Assessment Monitoring Plan, WSRC-RP-90-17-8, Revision 2. Savannah River Site, Aiken, SC.

WSRC (Westinghouse Savannah River Company), 1995. Sanitary Landfill Groundwater Quality Assessment Plan- Revision, WSRC-RP-95-1538, Revision 0. Savannah River Site, Aiken, SC.

WSRC (Westinghouse Savannah River Company), 1991, Safety Analysis Report, Savannah River Site, Generic Chapter 3.0: Site Characteristics (DOE Review Draft), WSRC-RP-91-188, Westinghouse Savannah River Laboratory, Aiken, SC, 29808.

WSRC (Westinghouse Savannah River Company), 1991. F-, H-, K-, and P-Area Acid Caustic Basins Groundwater Quality Assessment Plan, WSRC-TR-91-178, Revision 1. Savannah River Site, Aiken, SC.

WSRC (Westinghouse Savannah River Company), 1993a. Environmental Monitoring Section Environmental Geology Procedures, WSRC-3Q1-7. Savannah River Site, Aiken, SC.

WSRC (Westinghouse Savannah River Company), 1993b. Savannah River Site Environmental Report for 1992, "Groundwater." Savannah River Site, Aiken, SC.

WSRC (Westinghouse Savannah River Company), 1993c. 1993 Renewal Application for a RCRA Part B Permit, Savannah River Site, WSRC-IM-91-53, Volume I, Revision 2. Savannah River Site, Aiken, SC.

WSRC (Westinghouse Savannah River Company), 1994. Savannah River Site Environmental Report for 1993, "Groundwater." Savannah River Site, Aiken, SC.

WSRC (Westinghouse Savannah River Company), 1997. Hydrogeologic Data Collection Procedures and Specifications, 3Q5.Revision 3, Savannah River Site, Aiken, SC.

WSRC (Westinghouse Savannah River Company), 1998. Application for a Hazardous Waste Part B Post-Closure Care Permit, Metallurgical Hazardous Waste Management Facility, Volume XIV, Revision 4. Savannah River Site, Aiken, SC.

WSRC (Westinghouse Savannah River Company), 1999a. Application for a Post-Closure Permit, M-Area Hazardous Waste Management Facility, Volume III, Revision 12. Savannah River Site, Aiken, SC.

WSRC (Westinghouse Savannah River Company), 1999b. Application for a Hazardous Waste Part B Post-Closure Care Permit, F-Area Hazardous Waste Management Facility, Volume IV, Revision 10. Savannah River Site, Aiken, SC.

WSRC (Westinghouse Savannah River Company), 1999c. Application for a Hazardous Waste Part B Post-Closure Care Permit, H-Area Hazardous Waste Management Facility, Volume V, Revision 10. Savannah River Site, Aiken, SC. 
Zack, A. L., 1977, The occurrence, availability, and chemical quality of ground water, Grand Strand area and surrounding parts of Horry and Georgetown Counties, South Carolina, South Carolina Water Resources Commission Report No. 8, 100p., 9 separate plates. 